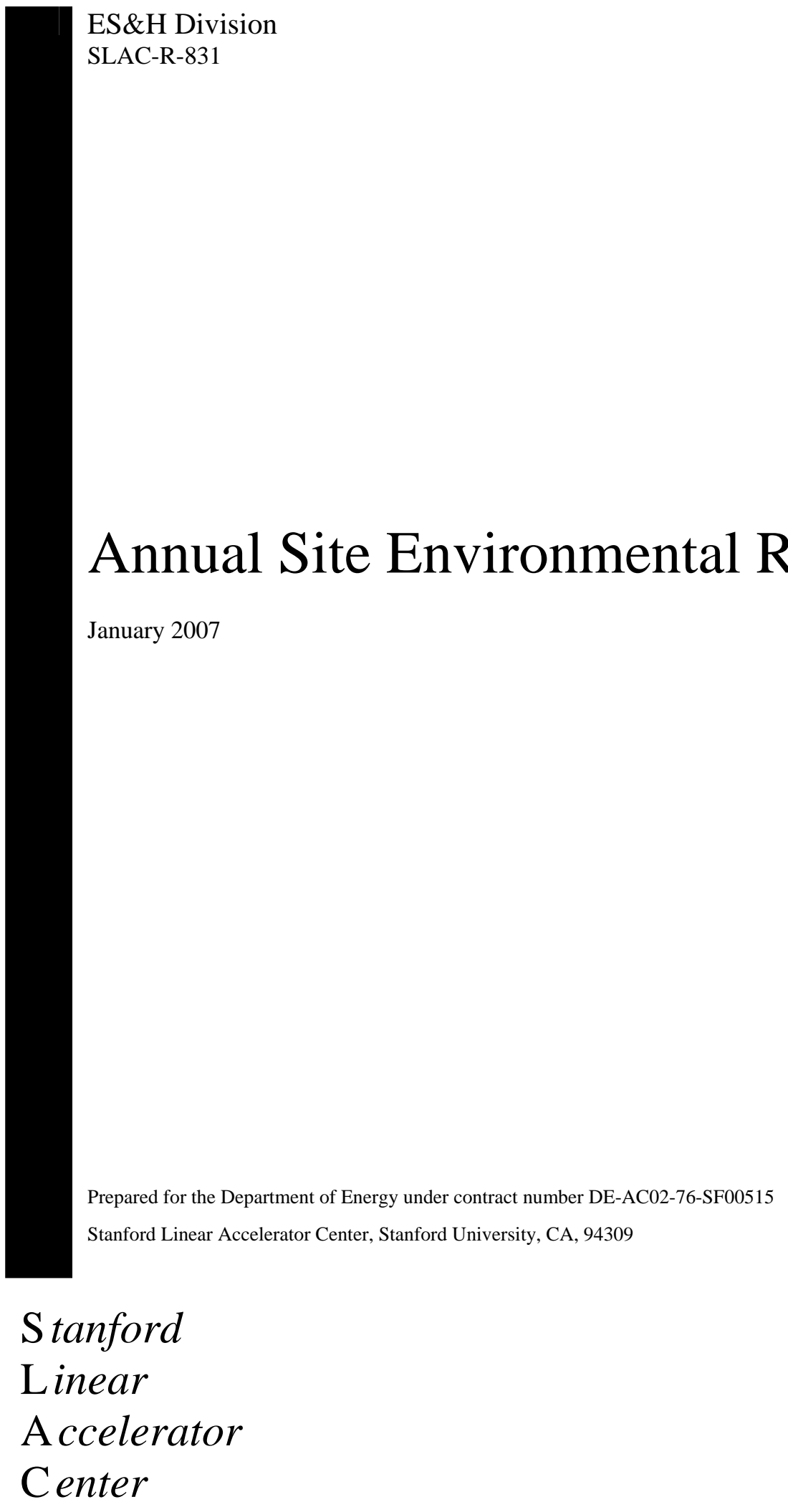

ES\&H Division

SLAC-R-831

\title{
Annual Site Environmental Report: 2005
}

January 2007

Prepared for the Department of Energy under contract number DE-AC02-76-SF00515

Stanford Linear Accelerator Center, Stanford University, CA, 94309

Stanford

Linear

Accelerator

Center

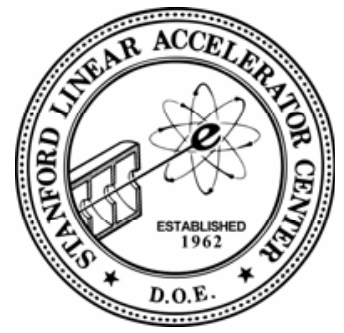




\section{Disclaimer}

This document, and the material and data contained therein, was developed under sponsorship of the United States Government. Neither the United States nor the Department of Energy, nor the Leland Stanford Junior University, nor their employees, makes any warranty, express or implied, or assumes any liability or responsibility for accuracy, completeness, or usefulness of any information, apparatus, product, or process disclosed, or represents that its use will not infringe privately owned rights. Mention of any product, its manufacturer, or suppliers will not, nor is it intended to, imply approval, disapproval, or fitness for any particular use. A royalty-free, non-exclusive right to use and disseminate same, for any purpose whatsoever, is expressly reserved to the United States and the university.

\section{Publication Data}

This document was designed and published by ES\&H Division Publishing

Document Title: Annual Site Environmental Report: 2005

Original Publication Date: January 2007

Original Source: ES\&H Division

Document Number: SLAC-R-831

Prepared for the United States Department of Energy under contract DE-AC02-76-SF00515

This report is available on line at http://www.slac.stanford.edu/pubs/slacreports/slac-r-831.html. Printed copies can be obtained by DOE employees and contractors from the Office of Scientific and Technical Information, PO Box 62, Oak Ridge, TN 37831 and by the public from the National Technical Information Service, US Department of Commerce, 5285 Port Royal Road, Springfield, VA 22161.

Comments on the report may be sent to

ES\&H Publishing Coordinator

eshpubs@slac.stanford.edu

Mailstop 84

Stanford Linear Accelerator Center

2575 Sand Hill Road

Menlo Park, CA 94025

Additional information about SLAC is available at http://www.slac.stanford.edu/ 


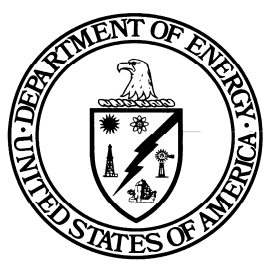

\section{U.S. Department of Energy \\ Office of Science (SC) \\ Stanford Site Office (SSO) \\ Stanford Linear Accelerator Center (SLAC) \\ 2575 Sand Hill Road, MS-8A \\ Menlo Park, CA 94025}

October 25, 2006

Subject: 2005 Annual Site Environmental Report (ASER) for the Stanford Linear Accelerator Center (SLAC)

This report, prepared by SLAC for the U.S. Department of Energy, Stanford Site Office (SSO), provides a comprehensive summary of the environmental program activities at SLAC for calendar year 2005. Annual Site Environmental Reports (ASERs) are prepared for all DOE sites with significant environmental activities, and distributed to relevant external regulatory agencies and other interested organizations or individuals.

To the best of my knowledge, this report accurately summarizes the results of the 2005

environmental monitoring, compliance, and restoration programs at SLAC. This assurance can be made based on SSO and SLAC review of the ASER, and quality assurance protocols applied to monitoring and data analyses at SLAC.

Any questions or comments regarding this report may be directed to Dave Osugi of the SSO at (650) 926-3305, or by mail to the address above.

Sincerely,

Nancy N. Sanchez

Manager

Stanford Site Office 



\section{Certification of Accuracy}

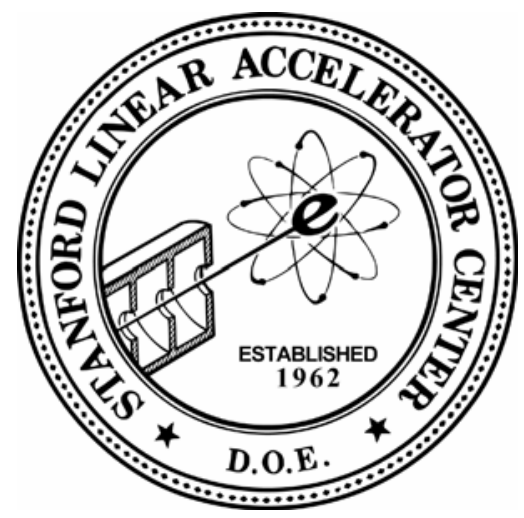

Annual Site Environmental Report

January - December 2005

SLAC-R-831

Stanford Linear Accelerator Center

I certify that the information submitted herein is current for the reporting period, accurate, and complete, based on my familiarity with the information and my inquiry of those individuals immediately responsible for obtaining the information.

Sayed Rokni

Date $\underline{10 / 2 / 2006}$

Acting Associate Director

Environment, Safety, and Health Division 



\section{Contents}

Figures $\quad$ V

Tables vii

Appendices $\quad$ ix

Preface

Organization $\quad x i$

Contributors xiii

Primary Coordinators and Authors $\quad$ xiii

Additional Authors xiii

Editing and Publishing xiii

Acronyms $\quad x v$

$\begin{array}{lr}\text { Executive Summary } & 1\end{array}$

Air Quality 1

Hazardous Waste 1

Stormwater and Industrial Wastewater 2

Hazardous Materials Program 2

Environmental Radiological Program $\quad 2$

Groundwater Protection and Environmental Restoration 2

1 Site Overview $1-1$

1.1 Introduction $1-1$

1.1.1 SLAC Mission 1-1

1.1.2 Research Program 1-1

1.2 Location $1-3$

1.3 Geology $1-4$

1.4 Climate $1-4$

1.5 Land Use $1-4$

1.6 Water Supply $1-4$

1.7 Demographics $1-5$

2 Environmental Compliance $2-1$

2.1 Introduction $2-1$

2.2 Regulatory Framework $2-1$

2.3 Environmental Permits and Notifications 2-1

2.4 Environmental Incidents $\quad 2-2$ 
2.4.1 Non-radiological Incidents $\quad 2-2$

2.4.2 Radiological Incidents $2-2$

2.5 Assessments, Inspections, and Quality Assurance 2-2

2.5.1 Assessments 2-2

2.5.2 Inspections 2-3

2.5.3 Quality Assurance 2-3

2.6 Environmental Performance Measures $\quad 2-4$

3 Management Systems $3-1$

3.1 Introduction 3-1

3.2 SLAC Organization $3-1$

3.3 ES\&H Division Organization $3-1$

3.3.1 Environmental Protection 3-1

3.3.2 Fire Department 3-1

3.3.3 Radiation Protection 3-2

3.3.4 Chemical and General Safety 3-2

3.3.5 Medical Department 3-2

3.3.6 Knowledge Management 3-2

3.4 Integrated Safety and Environmental Management System 3-2

3.4.1 Safety and Environmental Management System 3-2

3.4.2 Work Smart Standards 3-3

3.4.3 Environmental Performance Measures 3-3

3.4.4 Training 3-3

3.5 Environmental Management System 3-4

4 Environmental Non-radiological Programs $\quad 4-1$

4.1 Introduction 4-1

4.2 Air Quality Management Programs 4-2

4.2.1 Regulatory Framework 4-2

4.2.2 Program Status 4-3

4.2.3 Summary and Future Plans 4-8

4.3 Industrial and Sanitary Wastewater Management Program 4-8

4.3.1 Regulatory Framework 4-8

4.3.2 Program Status 4-10

4.3.3 Summary and Future Plans $\quad$ 4-14

4.4 Surface Water Management Program 4-14

4.4.1 Regulatory Framework 4-15

4.4.2 Program Status 4-16

4.4.3 Summary and Future Plans $\quad$ 4-18

4.5 Hazardous Materials Management 4-18

4.5.1 Regulatory Framework 4-19

4.5.2 Program Status 4-19

4.5.3 Hazardous Materials Business Plan Program 4-20

4.5.4 Toxics Release Inventory Program 4-20

4.5.5 California Accidental Release Prevention Program 4-21

4.5.6 Aboveground Storage Tank Program 4-21

4.5.7 Toxic Substances Control Act Program 4-22 
4.5.8 Chemical Management System 4-22

4.6 Waste Minimization and Management 4-22

4.6.1 Waste Minimization Accomplishments 4-23

4.6.2 Hazardous Waste Management 4-25

4.6.3 Non-hazardous Waste Management 4-30

4.6.4 Other Waste Management Activities 4-30

4.7 Environmental Planning 4-31

4.7.1 SLAC Long Range Development Plan 4-31

4.7.2 National Environmental Policy Act 4-32

5 Environmental Radiological Program $\quad$ 5-1

5.1 Introduction

5.2 Sources of Radiation and Radioactivity $\quad$ 5-1

5.3 Monitoring for Direct Radiation 5-2

5.4 Assessment of Airborne Radioactivity 5-2

5.5 Assessment of Radioactivity in Water 5-3

5.5.1 Industrial Wastewater 5-3

5.5.2 Stormwater 5-5

5.5.3 Groundwater 5-5

5.6 Assessment of Radioactivity in Soil $\quad$ 5-6

5.7 Release of Property Containing Residual Radioactive Material 5-6

5.8 Potential Dose to the Public $5-6$

5.9 Biota Dose $\quad$ 5-7

5.9.1 Dose to Biota from Direct Radiation 5-8

5.9.2 Dose to Biota from Activation Products 5-8

5.10 Low-level Radioactive Waste Management $\quad$ 5-8

6 Groundwater Protection and Environmental Restoration 6-1

6.1 Introduction 6-1

6.2 Background Conditions $\quad 6-1$

6.3 Areas with Potential Impact from Chemicals 6-2

6.4 Strategies for Controlling Potential Sources of Chemicals 6-2

6.5 Restoration Activities 6-2

6.6 Groundwater Characterization Monitoring Network 6-3

6.7 Groundwater Site Descriptions and Results 6-7

6.7.1 Former Solvent Underground Storage Tank 6-7

6.7.2 Former Hazardous Waste Storage Area 6-7

6.7.3 Plating Shop 6-8

6.7.4 Test Lab and Central Lab 6-8

6.7.5 Beam Dump East 6-9

6.7.6 Lower Salvage Yard 6-9

6.8 Soil Site Description and Results $\quad$ 6-9

6.8.1 Lower Salvage Yard 6-9 
6.8.2 IR-6 and IR-8 Drainage Channels

6-10

6.8.3 Bone Yard and Related Projects

6-10

6.8.4 Excavation Clearance Program

6-11 


\section{Figures}

Figure 1-1 SLAC Site Location $\quad$ 1-2

Figure 1-2 Site Area General Geographic and Geologic Setting 1-3

Figure 4-1 POC Emissions from BaBar (DCH-IFR/Sources S-55 and S-56) 4-4

Figure 4-2 Air Emissions from Chlorinated Solvents: SLAC Plating Shop, 1995-2005 4-6

Figure 4-3 Industrial and Sanitary Wastewater Monitoring Locations 4-10

Figure 4-4 Water Quality at the Sand Hill Road Station 4-11

Figure 4-5 Surface Water Monitoring Locations 4-16

Figure 4-6 Hazardous Waste Generation, 1995-2005 4-24

Figure 4-7 Municipal Solid Waste Recycling, 1995-2005 4-25

Figure 4-8 TSCA-Regulated Hazardous Waste, 1995-2005 4-28

Figure 4-9 Municipal Solid Waste Recycling and Disposal, 1995-2005 4-31

Figure 6-1 Groundwater Characterization Monitoring Network 6-4

Figure 6-2 Westside Groundwater Network and Impacted Areas 6-5

Figure 6-3 Eastside Groundwater Network and Impacted Areas 6-5 



\section{Tables}

Table 1-1 Populations of Communities near SLAC 1-6

Table 2-1 General Permits Held by SLAC 2-1

Table 2-2 Environmental Audits and Inspections $\quad$ 2-3

Table 4-1 Recent Environmental Awards $4-1$

Table 4-2 Halogenated Solvent Cleaning Sources Subject to NESHAPS 4-5

Table 4-3 Vehicle Fleet Summary 4-7

Table 4-4 Industrial and Sanitary Wastewater Monitoring Requirements 4-9

Table 4-5 Water Quality at the Sand Hill Road Station 4-12

Table 4-6 Water Quality at the Metal Finishing Pre-treatment Facility 4-13

Table 4-7 Cooling Tower 1701 Basin Results 4-14

Table 4-8 Water Quality Results and Comparison to Parameter Benchmark Values 4-18

Table 4-9 Aboveground Petroleum Tanks 4-21

Table 4-10 Waste Minimization and Pollution Prevention Projects 4-26

Table 4-11 Hazardous Waste Treatment Units Subject to Tiered Permitting 4-29

Table 4-12 NEPA Documentation Prepared during 2005 4-33

Table 5-1 Activation Products in Water or Air 5-2

Table 5-2 Airborne Radioactivity Released in 2005

Table 5-3 Radioactivity in Wastewater Released in 2005

Table 5-4 Summary of Radioactivity in SLAC Wastewater, 1995-2005 5-5

Table 5-5 Summary of Tritium Concentrations Measured in Monitoring Wells in 2005 5-6

Table 5-6 Summary of Potential Annual Doses due to SLAC Operations in 2005 5-7

Table 5-7 Potential Dose (mrem) to Maximally Exposed Individual, 1996-2005 5-8

Table 6-1 Monitoring Locations and Number of Wells 



\title{
Appendices
}

\author{
A Distribution List
}





\section{Preface}

To satisfy the requirements of the United States Department of Energy Order 231.1, "Environment, Safety and Health Reporting", the Environment, Safety, and Health (ES\&H) Division of the Stanford Linear Accelerator Center (SLAC) prepares an annual report describing its environmental programs and activities.

This Annual Site Environmental Report: 2005 summarizes SLAC's compliance with standards and requirements, describes the management and monitoring systems in place, and highlights significant accomplishments for the year.

\section{Organization}

The report is published in a single volume, organized into the following chapters:

- Chapter 1, "Site Overview”, describes the environmental setting of the Stanford Linear Accelerator Center (SLAC) and the activities conducted at the site

- Chapter 2, "Environmental Compliance”, gives an account of the regulatory framework and results concerning the site's environmental programs

- Chapter 3, "Management Systems”, outlines the organizational structure, methods, and responsibilities relevant to environmental programs

- Chapters 4, 5, and 6, respectively "Environmental Non-radiological Programs”, "Environmental Radiological Program”, and “Groundwater Protection and Environmental Restoration”, give more detailed accounts of the programs and their results for the year

An executive summary provides an overview of the report. 



\section{Contributors}

This report was prepared under the direction of Helen Nuckolls, ES\&H Division, Environmental Protection Department (EP).

\section{Primary Coordinators and Authors}

- Rich Cellamare (Chapter 4)

- Judy Fulton (Chapter 4)

- Mike Grissom (Chapter 3)

- $\quad$ Mike Hug (Chapter 4)

- Dellilah Sabba (executive summary, Chapters 1, 2 and 6)

- Kirk Stoddard (Chapter 4)

- Henry Tran (Chapter 5)

\section{Additional Authors}

- $\quad$ Neil Calder

- Dwight Harbaugh

- Adam Ng

\section{Editing and Publishing}

The Environmental Protection Department edited this report; ES\&H Division Publishing formatted and published it; SLAC Technical Publications provided electronic publishing and printing support. 



\section{Acronyms}

\begin{tabular}{ll} 
AEC & Atomic Energy Commission \\
ASER & annual site environmental report \\
AST & aboveground storage tank \\
BAAQMD & Bay Area Air Quality Management District \\
BaBar & SLAC B Factory detector \\
BMP & best management practice \\
BTU & British thermal unit \\
CAA & Clean Air Act \\
CAFO & Consent Agreement and Final Order \\
CalARP & California Accidental Release Prevention Program \\
CEF & Conventional and Experimental Facilities Department \\
CERCLA & Comprehensive Environmental Response, Compensation, and Liability Act \\
CFR & Code of Federal Regulations \\
CGS & Chemical and General Safety Department \\
Ci & curie \\
CMS & chemical management system \\
CUPA & certified unified program agency \\
CWA & Clean Water Act \\
CX & categorical exclusion \\
CY & calendar year \\
DOE & United States Department of Energy \\
DOELAP & Department of Energy's Laboratory Accreditation Program \\
DPE & dual-phase extraction \\
DTSC & California Department of Toxic Substances Control \\
DWS & drinking water standard \\
EA & environmental assessment \\
EIS & environmental impact statement \\
EMR & Emergency Planning and Community-Right-to-Know Act \\
EMS & ental management review \\
\hline
\end{tabular}




\begin{tabular}{|c|c|}
\hline EP & Environmental Protection Department \\
\hline ES\&H & environment, safety, and health \\
\hline FHWSA & Former Hazardous Waste Storage Area \\
\hline FMS & flow metering station \\
\hline FSUST & Former Solvent Underground Storage Tank \\
\hline FY & fiscal year \\
\hline GDF & gasoline dispensing facility \\
\hline $\mathrm{GeV}$ & giga-electron volt \\
\hline GHG & greenhouse gas \\
\hline gpd & gallons per day \\
\hline GSA & United States General Services Administration \\
\hline $\mathrm{H}-134 \mathrm{a}$ & tetrafluoroethane \\
\hline $\mathrm{H}_{2} \mathrm{NO}_{3}$ & nitric acid \\
\hline HAPs & hazardous air pollutants \\
\hline HMBP & hazardous materials business plan \\
\hline HVAC & heating, ventilation, and air conditioning \\
\hline IDPE & interim dual-phase extraction \\
\hline ILC & International Linear Collider \\
\hline INL & Idaho National Laboratory \\
\hline IR & interaction region \\
\hline ISEMS & integrated safety and environmental management system \\
\hline ISM & integrated safety management \\
\hline $\mathrm{km}$ & kilometer \\
\hline $\mathrm{L}$ & liter \\
\hline lbs & pounds \\
\hline linac & linear accelerator \\
\hline LCLS & Linac Coherent Light Source \\
\hline LLRW & low-level radioactive waste \\
\hline LRDP & long-range development plan \\
\hline LSY & Lower Salvage Yard \\
\hline $\mathrm{m}$ & meter \\
\hline MAPEP & mixed analyte performance evaluation program \\
\hline $\mathrm{M} \& \mathrm{O}$ & management and operating \\
\hline MEI & maximally exposed individual \\
\hline
\end{tabular}




\begin{tabular}{|c|c|}
\hline MFPF & metal finishing pre-treatment facility \\
\hline $\mathrm{mg}$ & milligram \\
\hline $\mathrm{mg} / \mathrm{L}$ & milligrams per liter \\
\hline MGE & Main Gate East Channel \\
\hline MPMWD & Menlo Park Municipal Water Department \\
\hline mrem & millirem \\
\hline $\mathrm{mSv}$ & milli Sievert \\
\hline NAE & North Adit East Channel \\
\hline NASA & National Aeronautics and Space Administration \\
\hline NEPA & National Environmental Policy Act \\
\hline NESHAPs & National Emission Standards for Hazardous Air Pollutants \\
\hline $\mathrm{NIH}$ & National Institutes of Health \\
\hline NOV & notice of violation \\
\hline NVLAP & National Voluntary Laboratory Accreditation Program \\
\hline NZE & near-zero emission \\
\hline OCA & offsite consequence analysis \\
\hline ODS & ozone-depleting substance \\
\hline PBR & permit by rule \\
\hline PBV & parameter benchmark value \\
\hline PCB & polychlorinated biphenyl \\
\hline $\mathrm{pCi}$ & picoCuries \\
\hline $\mathrm{pCi} / \mathrm{L}$ & picoCuries per liter \\
\hline PEP & Positron-Electron Project \\
\hline PHA & process hazard assessment \\
\hline POC & precursor organic compound \\
\hline ppd & pounds per day \\
\hline ppm & parts per million \\
\hline QA & quality assurance \\
\hline QC & quality control \\
\hline RACM & regulated asbestos-containing material \\
\hline RCRA & Resource Conservation and Recovery Act \\
\hline RMP & risk management plan \\
\hline $\mathrm{RP}$ & radiation protection \\
\hline RWQCB & regional water quality control board \\
\hline
\end{tabular}


SARA Superfund Amendments and Reauthorization Act

SBSA South Bayside System Authority

$\mathrm{SF}_{6} \quad$ sulfur hexafluoride

SLAC Stanford Linear Accelerator Center

SLC SLAC Linear Collider

SMCHSA San Mateo County Health Services Agency

SMOP synthetic minor operating permit

SMP self-monitoring program

SPCC spill prevention control and countermeasures

SPEAR Stanford Positron-Electron Asymmetric Ring

SSO Stanford Site Office

SSRL Stanford Synchrotron Radiation Laboratory

SVOC semi-volatile organic compound

SWMP stormwater monitoring program

SWPPP stormwater pollution prevention plan

SWRCB State Water Resources Control Board

TCA 1,1,1-trichloroethane

TDS total dissolved solids

TPH total petroleum hydrocarbons

TRI toxics release inventory

TSCA Toxic Substances Control Act

TSD treatment, storage, and disposal facility

TTO total toxic organics

UFC Uniform Fire Code

Unidocs Uniform documents

USEPA United States Environmental Protection Agency

UST underground storage tank

VOC volatile organic compound

WBSD West Bay Sanitary District

WM waste management

WSS work smart standard

WTS waste tracking system 


\section{Executive Summary}

This report provides information about environmental programs during 2005 at the Stanford Linear Accelerator Center (SLAC). Seasonal activities that span calendar years are also included.

Production of an annual site environmental report (ASER) is a requirement established by the United States Department of Energy (DOE) for all management and operating (M\&O) contractors throughout the DOE complex. SLAC is a federally-funded research and development center with Stanford University as the $\mathrm{M} \& \mathrm{O}$ contractor.

SLAC effectively applied environmental management in meeting the site's integrated safety and environmental management system (ISEMS) goals. For normal daily activities, all SLAC managers and supervisors are responsible for ensuring that proper procedures are followed so that

- Worker safety and health are protected

- The environment is protected

- Compliance is ensured

Throughout 2005, SLAC focused on these activities through the SLAC management systems (described in Chapter 3). These systems were also the way SLAC approached implementing "greening of the government" initiatives such as Executive Order 13148. The management systems at SLAC are effective, supporting compliance with all relevant statutory and regulatory requirements. There were no reportable releases to the environment from SLAC operations during 2005.

In addition, many improvements were continued during 2005, in waste minimization, recycling, stormwater drain system, groundwater restoration, and implementing a chemical management system (CMS) to better manage chemical use. Program-specific details are discussed below.

\section{Air Quality}

SLAC operates its air quality management program in compliance with its established permit conditions. During the 2005 annual inspection by the Bay Area Air Quality Management District (BAAQMD), a file review of past operations of an oil-water separator revealed two exceedances of the permit flow rate. A notice of violation (NOV) was issued by the BAAQMD. SLAC instituted measures to correct the situation and applied for an increase in the flow limit from the BAAQMD.

\section{Hazardous Waste}

The Environmental Health Division of the San Mateo County Health Services Agency is the California certified unified permitting agency (CUPA) responsible for overseeing hazardous materials and waste management at SLAC. The CUPA inspected SLAC's hazardous waste generation program, tiered permitting, and hazardous materials business plan in 2005. The inspection found everything to be satisfactory. The regulators were particularly impressed with SLAC's CMS mapping system that is under development. 


\section{Stormwater and Industrial Wastewater}

SLAC operates its industrial and sanitary wastewater management program in compliance with established permit conditions: 2005 was the ninth consecutive year that a review by the program regulators found everything to be satisfactory.

\section{Hazardous Materials Program}

Although SLAC has been successful in meeting the regulatory requirements for hazardous materials, it has decided to pursue a more active strategy in managing and reducing its use of such materials. The cornerstone of this effort is the implementation of a CMS.

\section{Environmental Radiological Program}

In 2005, no radiological incidents occurred that increased radiation levels or released radioactivity to the environment. In addition to managing its radioactive wastes safely and responsibly, SLAC worked to reduce the amount of waste generated. As detailed in Chapter 5, SLAC has implemented programs and systems to ensure compliance with all radiological requirements related to the environment.

\section{Groundwater Protection and Environmental Restoration}

In general, environmental concerns at SLAC are limited in number, small in scale and are actively being managed or eliminated. The Environmental Restoration Program continued work on site characterization and evaluation of remedial alternatives at four sites with volatile organic compounds (VOCs) in groundwater and several areas with polychlorinated biphenyls (PCBs) and lead in soil. SLAC received a new site cleanup requirements order (board order) during 2005 from the California Regional Water Quality Control Board, San Francisco Bay Region (RWQCB) for the investigation and remediation of impacted soil and groundwater. The new board order lists specific tasks and deadlines for the remedial investigation. All 2005 submittals to the board were completed on time. 


\section{Site Overview}

This chapter describes the environmental setting of SLAC and the activities conducted at the site.

For an overview of site environmental planning, including descriptions of environmental resources, see the long-range development plan prepared in 2002 (revised June 2003). ${ }^{1}$

\subsection{Introduction}

SLAC is a national research laboratory operated by Stanford University under contract to the Department of Energy (DOE). SLAC is located on the San Francisco Peninsula, about halfway between San Francisco and San Jose, California (see Figure 1-1). Current research and scientific user facilities are in areas of photon science and particle astrophysics. Five scientists have been awarded the Nobel Prize for work carried out at SLAC and there are 10 members of its faculty in the National Academies.

The majority of SLAC funding comes from DOE Office of Science, with smaller contributions from National Aeronautics and Space Administration (NASA), National Institute of Health (NIH), and other federal and non-federal sources.

\subsubsection{SLAC Mission}

\section{Photon Science Discoveries}

- To make discoveries in photon science at the frontiers of the ultrasmall and ultrafast in a wide spectrum of physical and life sciences

Particle and Particle Astrophysics Discoveries

- To make discoveries in particle and astroparticle physics to redefine humanity's understanding of what the universe is made of and the forces that control it

Operate Safely; Train the Best

- To operate a safe laboratory that employs and trains the best and brightest, helping to ensure the future economic strength and security of the nation

\subsubsection{Research Program}

SLAC has three major research areas. The first, in photon science, is to develop and support innovative, synchrotron-based methods and instrumentation to x-ray based studies of matter on length scales down to the nano- to atomic-level and on time scales from milli- down to femto-seconds. Photon science research

1 Stanford University Architect/Planning Office, Stanford Linear Accelerator Center Long Range Development Plan (December 2002, revised June 2003), http://wwwgroup.slac.stanford.edu/bsd/SLAC_LRDP_final.pdf 
includes complex, correlated and magnetic materials science, molecular environmental science, and structural biology; there is a rapidly developing new area of excellence in ultrafast $\mathrm{x}$-ray science.

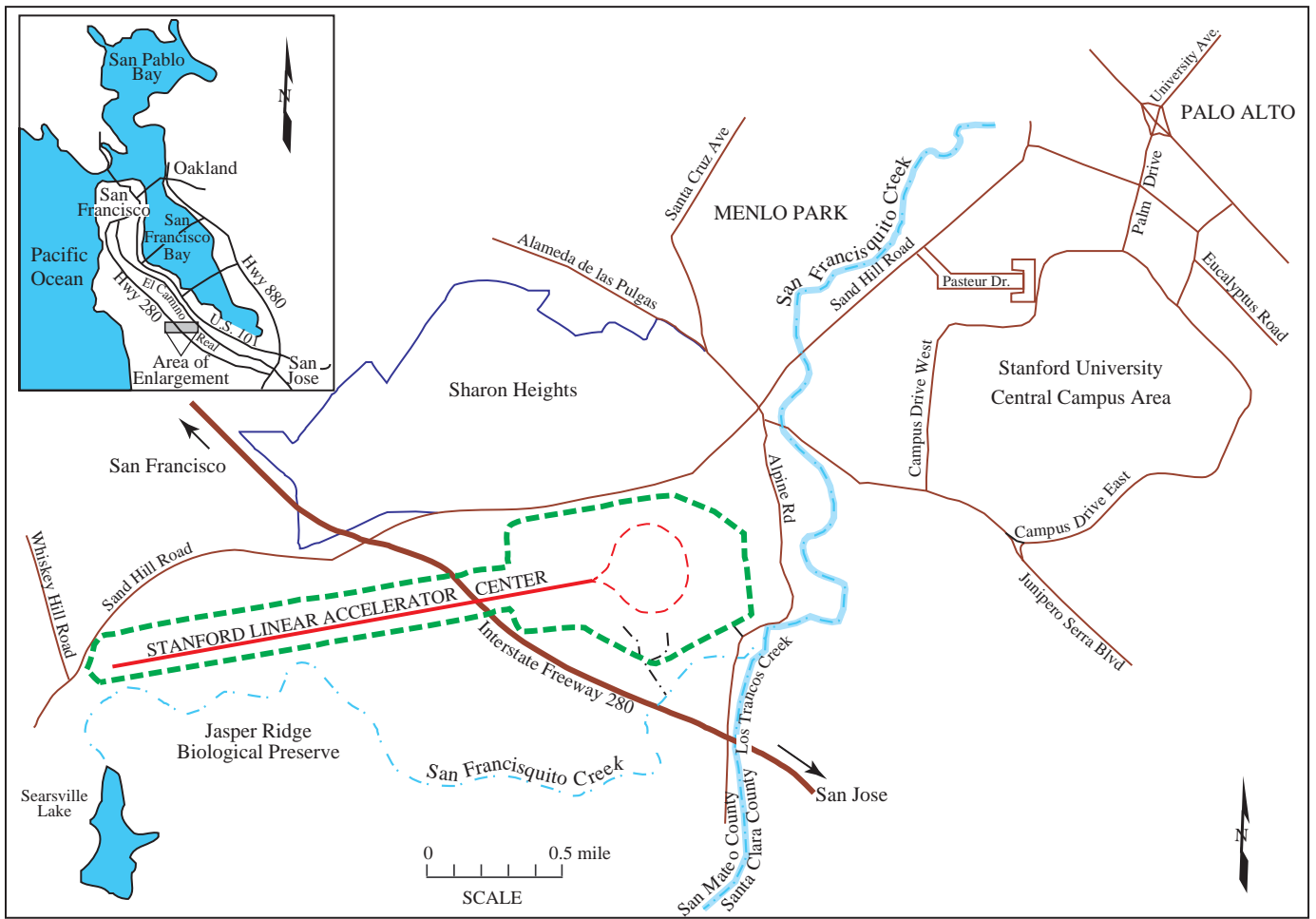

Figure 1-1 SLAC Site Location

A second research area is the use of particle accelerators and observatories in space and on the ground to understand what our universe is made of at its most basic and fundamental level. The principal areas of particle physics at the electron energy frontier using a linear collider, theoretical investigations of the quantum universe, and, at the Kavli Institute for Particle Astrophysics and Cosmology, non-accelerator tests of the Standard Cosmology Model through investigations of dark matter and dark energy.

Continuing over the next three years, a third research drive at SLAC is the construction of the Linac Coherent Light Source (LCLS), the world's first x-ray-free electron laser. SLAC is committed to the ontime and on-budget construction and rapid commissioning of this major new facility that will open revolutionary frontiers for photon science in the coming decades.

The main instrument of research is the 2-mile linear accelerator (linac), which generates high intensity beams of electrons and positrons up to 50 giga-electron volts $(\mathrm{GeV})$. The linac is also used for injecting electrons and positrons into colliding-beam storage rings for particle physics research.

The Positron-Electron Project (PEP) storage ring is about 875 yards in diameter. While the original PEP program was completed in 1990, the storage ring has since been upgraded to serve as an asymmetric $B$ factory (known as PEP-II) to study the B meson. PEP-II continued its program with the SLAC B Factory (BaBar) detector throughout 2005. 
A smaller storage ring, the Stanford Positron-Electron Asymmetric Ring (SPEAR), contains a separate, shorter linac and a booster ring for injecting accelerated beams of electrons. SPEAR is fully dedicated to synchrotron radiation research. The synchrotron light generated by the SPEAR storage ring is used by the Stanford Synchrotron Radiation Laboratory (SSRL), a division of SLAC, to perform experiments.

SLAC is committed to continuing its leadership in advocating and working on the design of the International Linear Collider (ILC) machine and the detector. The laboratory has the strongest electron accelerator group in the United States, if not the world, and in collaboration with our international partners will contribute to both the design and testing of major ILC subsystems as well as to the overall design.

\subsection{Location}

SLAC is located in a belt of low, rolling foothills between the alluvial plain bordering San Francisco Bay to the east and the Santa Cruz Mountains to the west. The site varies in elevation from 175 to 380 feet above sea level. The alluvial plain to the east around the bay lies less than 151 feet above sea level; the mountains to the west rise abruptly to over 2000 feet.

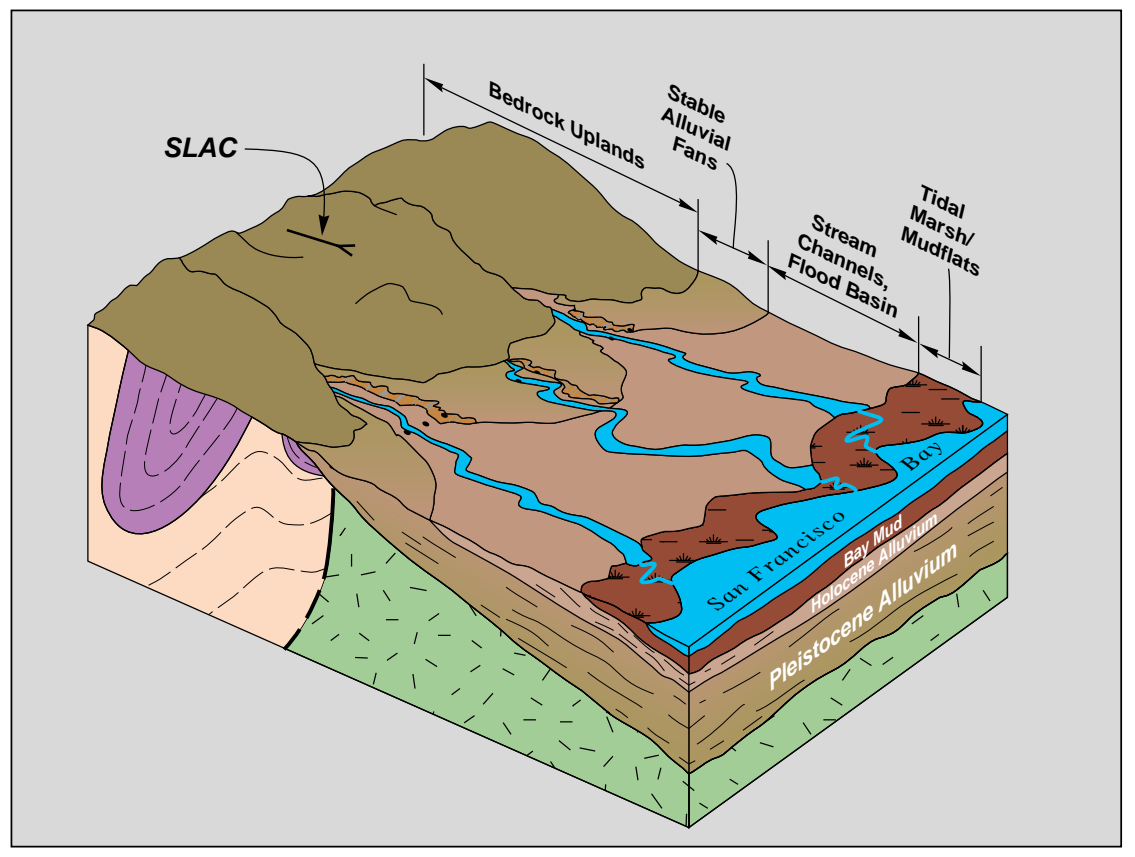

Figure 1-2 Site Area General Geographic and Geologic Setting

The site occupies 426 acres of land owned by Stanford University. The property was leased in 1962 for purposes of research into the basic properties of matter. The DOE now owns the original 50-year lease to the Atomic Energy Commission (AEC). The land is part of Stanford's academic reserve, and is located west of the university and the city of Palo Alto in an unincorporated portion of San Mateo County.

The site lies between Sand Hill Road and Alpine Road, bisected by Highway 280, on an elongated parcel roughly 2.75 miles long, running in an east-west direction. The parcel widens to about 0.65 mile at the target (east) end to allow space for buildings and experimental facilities. Much of the western end of the parcel is bordered by Stanford University's Jasper Ridge Biological Preserve, which includes part of the 
San Francisquito Creek riparian channel, the last channel of its kind between San Jose and San Francisco still in its natural state.

\subsection{Geology}

The SLAC site is underlain by sandstone, with some basalt at the far eastern end. In general, the bedrock on which the western half of the SLAC linac rests is the Whiskey Hill Formation (Eocene age), and the bedrock under the eastern half is the Ladera Sandstone (Miocene age). On top of this bedrock at various places along the accelerator alignment is the Santa Clara Formation (Pleistocene age), where alluvial deposits of sand and gravel are found. At the surface is a soil overburden of non-consolidated earth material averaging from 0.3 to 3 feet in depth. Figure 1-2 shows the general geographic and geologic setting of the area.

\subsection{Climate}

The climate in the SLAC area is Mediterranean. Winters are cool and moist, and summers are mostly warm and dry. Daily mean temperatures are seldom below 32 degrees Fahrenheit or above 86 degrees Fahrenheit.

Rainfall averages about 22 inches per year. The distribution of precipitation is highly seasonal. About 75 percent of the precipitation, including most of the major storms, occurs during the four-month period from December through March. Most winter storm periods are from two days to a week in duration. The storm centers are usually characterized by relatively heavy rainfall and high winds. The combination of topography and air movement produces substantial fluctuations in intensity, which can best be characterized as a series of storm cells following one another that produce heavy precipitation for periods of five to 15 minutes with lulls in between bursts.

\subsection{Land Use}

The SLAC site is in an unincorporated portion of San Mateo County and is zoned in the San Mateo County General Plan as a residential estate. Approximately 34 percent of the property is developed with buildings and pavement, mostly in the core campus area.

Land use to the immediate west is commercial, and farther west is agricultural and reserved open space. Land use to the north is mostly commercial, residential, and recreational (a golf course), with a school and convalescent hospital north of the central campus. Land use to the east is residential, recreational (another golf course), and educational (the Stanford campus). Land use to the south is agricultural (including a horse boarding and training facility), reserved open space, and residential.

\subsection{Water Supply}

SLAC domestic water is furnished via the Menlo Park Municipal Water Department (MPMWD), the source of which is the City of San Francisco-operated Hetch Hetchy aqueduct system, fed from reservoirs in the Sierra Nevada. SLAC and the neighboring Sharon Heights development (to the north), including the Stanford shopping center, receive water service from an independent system (called Zone 3) within the MPMWD. This separate system taps the Hetch Hetchy aqueduct and pumps water up to a 268,391-cubicfeet reservoir in Atherton north of Sand Hill Road, approximately 1.5 miles from central SLAC. 
The Zone 3 system was constructed in 1962 under special agreements between the City of Menlo Park, the Sharon Heights developer, Stanford University, and the DOE. The cost of construction, including reservoir, pump station, and transmission lines, was shared among the various parties, so each party has a vested interest in the system, and is entitled to certain capacity rights in accordance with these agreements.

Drinking and process water are both transported throughout SLAC by a distribution system protected by backflow prevention devices. SLAC has no drinking-water supply wells. The drinking-water supply well nearest to SLAC is about 1,500 feet from the SLAC boundary.

Use of water at SLAC is about equally divided between water used to cool equipment (such as the linear accelerator) and domestic uses (such as landscape irrigation and drinking water). The average water consumption by SLAC in 2005 was 35,355 cubic feet per day, or 12,904,600 cubic feet total.

\subsection{Demographics}

SLAC's primary customers are the approximately 3,000 students, postdoctoral students, and scientists from around the world who make use of its accelerator-based instrumentation and techniques for their research. SLAC has a working population of about 1,500, of which about 265 are PhD physicists. Approximately 730 staff members are professional, including physicists, engineers, programmers, and other scientificrelated personnel. The balance of the staff comprises support personnel, including technicians, crafts personnel, laboratory assistants, and administrative assistants. In addition to the regular population, at any given time SLAC hosts between 900 and 1,000 visiting scientists.

The populated area around SLAC is a mix of offices, schools, single-family housing, apartments, condominiums, and Stanford University. Approximately 3,500 people live within a one-mile radius of central SLAC. SLAC is mainly surrounded by five communities: the city of Menlo Park; the towns of Atherton, Portola Valley, and Woodside; and the unincorporated community of Stanford University, which is in Santa Clara County. Nearby unincorporated communities in San Mateo County include Ladera and two neighborhoods in western Menlo Park.

Table 1-1provides a summary of populations in the communities around SLAC. Within one mile of SLAC's perimeter are two public and two private schools with elementary and/or middle school students. 
Table 1-1 Populations of Communities near SLAC

\begin{tabular}{lllr} 
Type & Community & County & Population \\
\hline Incorporated town or city & Atherton & San Mateo & 7,194 \\
& Menlo Park & San Mateo & 30,785 \\
& Palo Alto & Santa Clara & 58,598 \\
& Portola Valley & San Mateo & 4,462 \\
& Woodside & San Mateo & 5,352 \\
& Ladera & San Mateo & 1,492 \\
Unincorporated community & Stanford & Santa Clara & 13,200 \\
& West Menlo Park & San Mateo & 3,629 \\
& Weekend Acres & San Mateo & 268 \\
& & & 124,980 \\
Total & & \\
Sources: & & \\
1 Census 2000 data from the San Mateo County web site and from US Census Bureau site & \\
2 Stanford population from Stanford University Planning Department estimates \\
Note: Population in unincorporated areas outside the defined communities is not included
\end{tabular}




\section{Environmental Compliance}

\subsection{Introduction}

This chapter provides a summary of the regulatory framework within which the environmental programs of SLAC operate, and compliance with those regulations for 2005.

\subsection{Regulatory Framework}

The SLAC Work Smart Standards (WSS) identify environmental protection and safety requirements and standards that are followed throughout the facility. ${ }^{2}$

\subsection{Environmental Permits and Notifications}

The permits held by SLAC in 2005 are shown in Table 2-1.

Table 2-1 General Permits Held by SLAC

\begin{tabular}{|c|c|c|c|}
\hline Issuing Agency & Permit Type & Description & Number \\
\hline \multirow[t]{2}{*}{$\begin{array}{l}\text { Bay Area Air Quality } \\
\text { Management District }\end{array}$} & Air quality & $\begin{array}{l}\text { Synthetic minor operating permit, issued per Title V } \\
\text { of the Clean Air Act }\end{array}$ & 1 \\
\hline & & $\begin{array}{l}34 \text { permitted sources and } 21 \text { exempt sources for } \\
\text { operation of various types of equipment }\end{array}$ & 55 \\
\hline \multirow[t]{5}{*}{$\begin{array}{l}\text { California Department of } \\
\text { Toxic Substance Control }\end{array}$} & $\begin{array}{l}\text { Hazardous waste } \\
\text { treatment }\end{array}$ & $\begin{array}{l}\text { Unit } 1 \mathrm{~A} \text { - Building } 025 \text {, permit by rule (PBR) for } \\
\text { cyanide treatment tanks }\end{array}$ & 1 \\
\hline & & $\begin{array}{l}\text { Unit } 1 \mathrm{~B} \text { - Building } 038, \text { PBR for metal finishing } \\
\text { pretreatment facility }\end{array}$ & 1 \\
\hline & & $\begin{array}{l}\text { Unit } 1 \mathrm{C} \text { - Building } 038, \mathrm{PBR} \text { for batch hazardous } \\
\text { waste treatment tank }\end{array}$ & 1 \\
\hline & & Unit 2 - Building 038, PBR for sludge dryer & 1 \\
\hline & & $\begin{array}{l}\text { Unit } 3 \text { - Building 460, conditional authorization permit } \\
\text { for batch treatment plant, facility shut down May } \\
2002\end{array}$ & 0 \\
\hline
\end{tabular}

2 Stanford Linear Accelerator Center, "Work Smart Standards", http://wwwgroup.slac.stanford.edu/esh/general/isems/wss/wssweb.htm 


\begin{tabular}{lllr} 
Issuing Agency & Permit Type & Description & Number \\
\hline & & $\begin{array}{l}\text { Unit 4 - Building 035, conditional authorization permit } \\
\text { for groundwater treatment system } \\
\text { Unit 5 - Former Hazardous Waste Storage Area, } \\
\text { PBR for groundwater treatment system }\end{array}$ & 1 \\
& & Flow meter station at Sand Hill Road & 1 \\
\hline $\begin{array}{l}\text { South Bayside System } \\
\text { Authority and West Bay }\end{array}$ & $\begin{array}{l}\text { Wastewater } \\
\text { discharge }\end{array}$ & Metal finishing pre-treatment facility & 1 \\
& & $\begin{array}{l}\text { Treated groundwater discharge at Building 035 and } \\
\text { the Former Hazardous Waste Storage Area }\end{array}$ & 2 \\
\hline $\begin{array}{l}\text { Regional Water Quality } \\
\text { Control Board }\end{array}$ & Stormwater & Industrial activities stormwater general permit & 1 \\
\hline $\begin{array}{l}\text { US Environmental Protection Hazardous waste } \\
\text { Agency }\end{array}$ & Hazardous waste generator permit & 1
\end{tabular}

\subsection{Environmental Incidents}

\subsubsection{Non-radiological Incidents}

A single NOV was issued to SLAC by the BAAQMD for two exceedances of the permitted flow rate of an oil-water separator, no releases were involved however. Other than this, SLAC was in compliance with all non-radiological requirements related to the environment throughout 2005.

\subsubsection{Radiological Incidents}

In 2005, no radiological incidents occurred that increased radiation levels or released radioactivity to the environment. As detailed in Chapter 5, "Environmental Radiological Program”, SLAC was in compliance with all radiological requirements related to the environment throughout 2005.

\subsection{Assessments, Inspections, and Quality Assurance}

As described in Chapter 3, "Management Systems", the environmental programs at SLAC are subject to a number of assessments, inspections, and quality assurance measures. Those conducted during 2005 are reported here.

\subsubsection{Assessments}

\subsubsection{External}

External assessments are periodically conducted on varying basis. There is one monitoring assessment related to the radiological program which occurs regularly, and that is the quarterly monitoring of SLAC perimeter radiation by the California Department of Health Services. Monitoring results from the California Department of Health Services were not shared with SLAC. 
A water efficiency survey of SLAC was performed by Maddaus Water Management on November 4, 2005. Recommendations were made to improve the efficiency of water use at SLAC.

\subsubsection{Independent Assessments}

The DOE audited SLAC’s ISEMS program on August 18, and October 3 to 11, 2005.

At SLAC's request, the United States Environmental Protection Agency (USEPA) performed a review of SLAC’s environmental management system (EMS) in March 2005.

Two other independent Environment, Safety and Health audits occurred in March and April 2005. SLAC's ISEMS and EMS were evaluated by members of DOE's Office of Science Chicago and Oak Ridge Integrated Support Centers in September, October, and November of 2005. The DOE Stanford Site Office (SSO) then sent a self-declaration letter to the director of the Office of Science fulfilling the requirement under DOE Order 450.1, "Environmental Protection Program,, ${ }^{3}$ and Executive Order 13148 requiring all sites to have an EMS in place by the end of December 2005.

\subsubsection{Inspections}

Periodic inspections of the environmental programs are performed at SLAC by environmental regulatory agencies. Table 2-2 lists the inspections conducted in 2005 by these agencies. A single NOV was issued to SLAC by the BAAQMD for the exceedance of the permitted flow rate.

Table 2-2 Environmental Audits and Inspections

\begin{tabular}{lllr} 
Regulatory Agency & Inspection Title & Date & Violations \\
\hline $\begin{array}{l}\text { South Bayside System Authority } \\
\begin{array}{l}\text { Bay Area Air Quality Management } \\
\text { District }\end{array}\end{array}$ & Annual Wastewater Discharge Inspection & March 2 & 0 \\
$\begin{array}{l}\text { San Mateo County Department of } \\
\text { Health Services }\end{array}$ & $\begin{array}{l}\text { Hazardous waste generation program, } \\
\text { tiered permitting, and hazardous materials } \\
\text { business plan }\end{array}$ & August 24 & 1 \\
\hline
\end{tabular}

\subsubsection{Quality Assurance}

The SLAC site-wide quality assurance (QA) program is consistent with by the requirements of DOE Order 414.1C, ${ }^{4}$ and has roles, responsibilities, and authorities for implementing the ten criteria from the DOE order are included in the SLAC Institutional QA Program Plan. ${ }^{5}$

3 United States Department of Energy, DOE Order 450.1, "Environmental Protection Program”, http://www.directives.doe.gov/pdfs/doe/doetext/neword/450/o4501c2.html

4 United States Department of Energy, DOE Order 414.1C, “Quality Assurance”, http://www.directives.doe.gov/pdfs/doe/doetext/neword/414/o4141c.html

5 Stanford Linear Accelerator Center, Environment, Safety, and Health Division, SLAC Institutional Quality Assurance Program Plan (SLAC-I-770-0A17M-001), http://wwwgroup.slac.stanford.edu/esh/references/QAplan.pdf 
The Office of Assurance (established shortly after the start of 2006) is responsible for:

- Auditing quality assurance for line work as well as ES\&H programs

- Maintaining the SLAC Institutional Quality Assurance Program Plan

- Providing direction for implementation of the ten criteria from DOE Order 414.1C

\subsubsection{Environmental Non-radiological Program}

The Environmental Restoration Program uses the Quality Assurance Project Plan for the Remedial Investigation and Feasibility Study ${ }^{6}$ for soil and groundwater contamination investigations. This document has most components required of quality assurance project plans according to the USEPA; the Comprehensive Environmental Response, Compensation, and Liability Act (CERCLA, or Superfund); and DOE guidance documents. The components include defining required laboratory and field QA and quality control (QC) procedures and corrective actions, and data validation and reporting.

\subsubsection{Environmental Radiological Program}

Twice a year SLAC participates in the Mixed Analyte Performance Evaluation Program (MAPEP) held by DOE Idaho National Laboratory (INL). Under this program, the INL provided the SLAC Radioanalysis Laboratory with samples that contained unknown gamma- and beta-emitting radionuclides. The lab used these samples to test and improve its gamma counting and liquid scintillation counting capabilities. This ensures that the lab’s counting system performs accurate measurements.

\subsection{Environmental Performance Measures}

At the institutional level, a program of performance measures in environmental protection, waste minimization, pollution prevention and EMS have been established. ${ }^{7}$ Review of performance to these measures by senior management is part of the overall planned program assessment activities.

Performance measure results are reported in a fiscal year structure; the SLAC fiscal year 2005 (FY05) covered October 1, 2004 through September 30, 2005. The performance measure results for FY05 indicated a rating of outstanding on environmental measures, ${ }^{8}$ which is the highest attainable rating.

6 Stanford Linear Accelerator Center, Environment, Safety, and Health Division, Environmental Protection and Restoration Department, Quality Assurance Project Plan for the Remedial Investigation and Feasibility Study (SLAC-I-750-2A17M-002, March 2002)

7 Stanford Linear Accelerator Center, Environment, Safety, and Health Division, "ISEMS: Performance Measures” (FY 2004), http://www-group.slac.stanford.edu/esh/general/isems/perfmeas/

8 Stanford Linear Accelerator Center, Environment, Safety, and Health Division, Final Draft, Annual Environment, Safety, and Health Report (November 2005) 


\section{Management Systems}

\subsection{Introduction}

This chapter provides an overview of the Environment, Safety, and Health (ES\&H) Division's management systems, including organizational structure, management approach, and EMS implementation. The results for the various measures and reviews discussed below are contained in Chapter 2, "Environmental Compliance”.

\subsection{SLAC Organization}

In May of 2005, an extensive reorganization of the SLAC Directorates took place in anticipation of a change in program at SLAC from DOE High Energy Physics funded activities to DOE Basic Energy Sciences funded activities by the end of FY08. The previous organization of the SLAC directorates had been in place for many years: Director's Office, Business Services Division, ES\&H Division, Research Division, Stanford Synchrotron Research Laboratory (SSRL) Division, and Technical Division. After the reorganization, elements of the old directorates were reassigned to Director's Office, Operations Directorate, Photon Sciences Directorate, Particle and Particle Astrophysics Directorate, and LCLS Construction Directorate. Specifically, the Business Services and ES\&H Divisions were reassigned to the Operations Directorate while the SSRL Division was reassigned to the Photon Sciences Directorate.

\subsection{ES\&H Division Organization}

The ES\&H Division consists of six departments (see below) and a division office. The division office is tasked with overall strategic planning and management. The shared goal is to ensure SLAC operates in compliance with federal, state, and local regulations, as well as DOE requirements.

\subsubsection{Environmental Protection}

The Environmental Protection (EP) Department has three technical groups. The EP and compliance group provided oversight of stormwater and industrial wastewater, toxic substance control, and groundwater protection. The Environmental Restoration Group oversaw work to restore property impacted with chemicals. The Waste Management (WM) Group developed and implemented waste minimization and pollution prevention plans, and coordinated the disposal of regulated waste.

\subsubsection{Fire Department}

During 2005, the Fire Department, staffed by fire personnel from the Palo Alto Fire Department, continued to report to the ES\&H division office. Fire protection services were provided to the site on a 24 hour-a-day, seven days-a-week basis. 


\subsubsection{Radiation Protection}

The Radiation Protection Department (RP) has four technical groups. The Radiation Physics Group provided expertise in shielding design for new experiments and facilities, and provided oversight for safe operation of beam lines to protect workers, members of the general public and the environment. The Field Operations Group oversaw radiological monitoring and control. The Dosimetry and Radiological Environmental Group oversaw dosimetry and environmental impact monitoring and assessment. The Radioactive Waste and Material Accountability Group oversaw radioactive waste management at SLAC.

\subsubsection{Chemical and General Safety}

The Chemical and General Safety (CGS) Department managed the overall safety, and health programs, as well as hazardous materials management, the chemical management system (CMS) and the nonradiological air quality program. .

\subsubsection{Medical Department}

During 2005, the Medical Department, staffed by contract professional medical personnel, continued to report to the ES\&H division office. The Medical Department provided a full range of occupational medicine services.

\subsubsection{Knowledge Management}

The Knowledge Management Department provided training, publishing, and web services, and managed the division budget.

\subsection{Integrated Safety and Environmental Management System}

The ES\&H program has been designed to ensure SLAC operates in a safe, environmentally responsible manner and complies with applicable laws, regulations, and standards. The program is based on integrating these concerns into the mission and everyday operations of the site, and as such embodied the ISEMS approach even before this was made a DOE requirement and incorporated into the operating contract of the site. In 2005, the elements of ISEMS were extensively revised to further emphasize line management and individual responsibility. The revisions to the ISEMS program at SLAC were guided by an integrated safety management (ISM) steering committee with representatives from all the directorates at SLAC, including the ES\&H Division.

\subsubsection{Safety and Environmental Management System}

The "plan, do, check, and improve" approach of ISEMS ${ }^{9}$ has been formally adopted by SLAC, and is the foundation of the site's ISEMS ${ }^{10}$ and the ES\&H program. The approach consists of the following five core functions:

9 Stanford Linear Accelerator Center, Environment, Safety, and Health Division, "Integrated Safety and Environmental Management Systems”, http://www-group.slac.stanford.edu/esh/general/isems/ 
1. Define the scope of work

2. Analyze the hazards

3. Develop and implement hazard controls

4. Perform work within controls

5. Provide feedback and continuous improvement

\subsubsection{Work Smart Standards}

To ensure the goals of Guiding Principle 5, “Identification of Safety and Environmental Standards”, are met, the laws and regulations that specify the environment, safety, and health requirements of the laboratory have been identified and incorporated into the SLAC management and operating contract. These requirements, known as the SLAC WSS, are reviewed annually, and are based on and respond to potential hazards and environmental impacts identified by those who work at SLAC. ${ }^{11}$ As a result of activities related to the serious accident that occurred at SLAC on October 11, 2004, the FY05 WSS review was not finalized by agreement with the DOE Stanford Site Office until late in calendar year (CY) 2005.

\subsubsection{Environmental Performance Measures}

In addition to adopting work smart standards, SLAC evaluates its activities against performance measures. The environmentally relevant measures are:

- Environmental violations and releases

- Environmental restoration goals

- Waste minimization/pollution prevention goals

- Hazardous and radioactive waste

Specific performance measures are adopted and reported in a fiscal-year structure. ${ }^{12}$ The performance measure results for FY05 indicated a rating of outstanding on environmental measures.

\subsubsection{Training}

To ensure every employee is both aware and capable of fulfilling his or her responsibilities, the ES\&H Division operates an extensive program of classroom- and computer-based training. For example, personnel who handle hazardous chemicals and waste are instructed in chemical and waste management, waste minimization, pollution prevention, stormwater protection, on-site transportation of hazardous

10 Stanford Linear Accelerator Center, Environment, Safety, and Health Division, SLAC Integrated Safety and Environmental Management System Description (SLAC-I-720-0A00B-001), http://wwwgroup.slac.stanford.edu/esh/general/isems/sms.pdf

11 Stanford Linear Accelerator Center, “Work Smart Standards Set”, http://wwwgroup.slac.stanford.edu/esh/general/isems/wss/wssweb.htm

12 The measures for fiscal years 1997 through 2005 can be found on line at http://wwwgroup.slac.stanford.edu/esh/general/isems/perfmeas/. 
chemicals and waste, and spill and emergency response. Details on the ES\&H training program are available on line. ${ }^{13}$

\subsection{Environmental Management System}

Stanford University provides the land for the SLAC site to the DOE at no cost, charging no rent and exacting no fee. SLAC, as a department of the university, manages the land with future generations in mind, thus ensuring proper stewardship and the eventual return of the land to unrestricted use. This stewardship goal is embodied in the safety management system described above, which already incorporates many of the characteristics and requirements of an EMS as defined in Executive Order 13148, "Greening the Government", including the roles and responsibilities for an EMS.

Requirements for an EMS are contained in the order, DOE O 450.1, "Environmental Protection Program". ${ }^{14}$ SLAC continued to follow the path to self declare an EMS. An Environmental Management Review (EMR) was conducted at SLAC by the USEPA (Region 9) in March 2005. Corrective actions were taken in response to the EMR and a DOE review of the SLAC EMS program was conducted in November 2005. The DOE confirmed an EMS was in place at SLAC as of December 31, 2005 as required by the above directives.

13 Stanford Linear Accelerator Center, Environment, Safety, and Health Division, “Training”, http://wwwgroup.slac.stanford.edu/esh/training/

14 United States Department of Energy, DOE Order 450.1, “Environmental Protection Program”, http://www.directives.doe.gov/pdfs/doe/doetext/neword/450/o4501c2.html 


\section{Environmental Non-radiological Programs}

\subsection{Introduction}

During the course of "providing accelerators, detectors, instrumentation, and support for national and international research programs", SLAC manufactures and maintains one-of-a-kind research equipment, which requires the use and management of industrial chemicals, gases, and metals. In addition, SLAC has the potential to impact the environment due to storage and handling of chemicals and the large quantities of electricity and cooling water that are used in the operation of the accelerator. Finally, SLAC has environmental management issues relevant for any employer with more than 1,500 full-time staff, 3,000 scientific users per year, more than 230 vehicles, hundreds of buildings, and 426 acres of land located in an environmentally sensitive location.

SLAC expends considerable effort to minimize waste and emissions. If possible, SLAC avoids creating waste and emissions in the first place. When unavoidable, SLAC minimizes the amount it does produce, and then carefully manages the impacts that may occur as a result of waste generation.

As noted in Chapter 2, for FY05, the DOE recognized SLAC's environmental performance as outstanding (the highest possible rating) for each of the four environmental performance measures included in Stanford University's contract with DOE to manage the facility. Other recent recognition of SLAC's environmental performance accomplishments is provided in Table 4-1.

Table 4-1 Recent Environmental Awards

\begin{tabular}{|c|c|c|c|}
\hline Year & Organization & Award/Recognition Program & Description \\
\hline 2001 & White House & Closing the Circle Award & Reuse of potential hazardous wastes \\
\hline 2001 & Santa Clara County & Letter of recognition & $\begin{array}{l}\text { Silicon Valley Chemical Management } \\
\text { Services Pilot Project participant }\end{array}$ \\
\hline 2001 & DOE & Pollution Prevention Award & $\begin{array}{l}\text { Implementing alternatives to ozone- } \\
\text { depleting solvents }\end{array}$ \\
\hline 2001 & DOE & Pollution Prevention Award & $\begin{array}{l}\text { Reducing/eliminating hazardous waste } \\
\text { generation }\end{array}$ \\
\hline 2002 & USEPA & Champion of Green Government Award & $\begin{array}{l}\text { Identifying/developing alternatives to ozone } \\
\text { depleting solvents }\end{array}$ \\
\hline 2003 & USEPA & Champion of Green Government Award & $\begin{array}{l}\text { Reuse and reclamation of hazardous } \\
\text { materials, and reduction of hazardous } \\
\text { waste generation }\end{array}$ \\
\hline 2004 & DOE & Pollution Prevention Award & $\begin{array}{l}\text { Development of a site-wide chemical } \\
\text { management system }\end{array}$ \\
\hline 2004 & USEPA & Champion of Green Government Award & $\begin{array}{l}\text { By upgrading lighting in Klystron Gallery } \\
\text { will save } \$ 236,000 \text { annually }\end{array}$ \\
\hline
\end{tabular}


Additionally, SLAC continually strives to increase its environmental performance, per the objectives of Executive Order 13148, "Greening the Government through Leadership in Environmental Management”, and its own EMS (see Chapter 3).

This chapter provides an overview of the non-radiological environmental programs SLAC has implemented to protect air and water quality, to manage hazardous materials safely, and to minimize the generation of hazardous, non-hazardous, and solid waste. The chapter sections are organized by protection program and, describe the regulatory framework, program status for 2005, and relevant performance trends. The radiological environmental program is discussed in Chapter 5 , and programs covering the monitoring and remediation of groundwater, soil, and sediment are discussed in Chapter 6 .

\subsection{Air Quality Management Programs}

SLAC operates various sources of air pollution, including boilers, solvent degreasers, a paint shop, a plating shop, several machine shops, a magnet shop, and a vehicle fueling station. In addition, high-energy physics experiments can emit volatile organics due to the nature of the gas atmospheres required for use in particle detectors. This section describes the regulatory framework to which SLAC is subject for the purpose of air quality protection, and then presents the status of SLAC's air quality protection programs in 2005.

\subsubsection{Regulatory Framework}

In the San Francisco Bay Area, most federal and state air regulatory programs are implemented through the rules and regulations of the BAAQMD. Included in the BAAQMD roles and responsibilities are implementation of Title V of the Clean Air Act (CAA). As a result of this implementation, SLAC became subject to the Title $\mathrm{V}$ permitting program and applied for a synthetic minor operating permit (SMOP). SLAC's Title V SMOP application was submitted on June 1, 2000, and the permit was issued to SLAC by the BAAQMD on July 26, 2002.

The Title V SMOP placed caps on facility-wide emissions of VOCs, total hazardous air pollutants (HAPs), and individual HAPs. SLAC's first annual emissions report under the Title V SMOP was submitted to BAAQMD on time in July 2003.

Other mechanisms by which BAAQMD regulates SLAC's air emissions include

1. Annual enforcement inspections

2. New source permit evaluations

3. Annual information updates for emissions of air toxics as identified by the California Air Resources Board in its toxic substances checklist

4. Annual information updates for adhesives usage as specified in BAAQMD Regulation 8-51-1502.2C

5. Asbestos and demolition project notification requirements

SLAC is also subject to the following two air quality programs:

- The National Emission Standards for Halogenated Solvent Cleaning, under Title 40, Code of Federal Regulations (CFR), Part 63.460, administered through the Air Division of Region 9 of USEPA

- The Protection of Stratospheric Ozone, under 40 CFR 82, likewise administered through the Air Division of USEPA Region 9 


\subsubsection{Program Status}

\subsubsection{Annual Facility Enforcement Inspection}

BAAQMD conducted an annual facility-wide inspection on August 24, 2005. A file review of past operations revealed two exceedances of the permitted flow limit at the oil-water separator which receives effluent from a steam-cleaning operations facility. As a result, an NOV was issued to SLAC. In response, SLAC instituted daily recording of the flow and applied for an increase in the flow limit, which was granted early in 2006.

\subsubsection{New Source Permits}

In August 2005, SLAC submitted three individual permit applications to BAAQMD to separate the three subsystems of the BaBar detector that use isobutane. The permits reflect the fact that each subsystem is a unique entity. As such, each subsystem now has its own limit for isobutane emissions, and can be managed independently.

An interim soil vapor extraction system at the former hazardous waste storage area (see Chapter 6) was converted to a full-scale dual-phase extraction system, and permits for both the extraction system and its abatement device were submitted in November 2005. In last year's report, the system was approved for unabated operation, because after initial high concentrations and rapid subsequent decreases, VOC levels were consistently low and within the permitted limits.

The boiler next to the Plating Shop in Building 37 was taken out of service in 2004 and a replacement boiler was installed next to it in April 2005. Since the heating capacity of the new unit is less than 10 million British thermal units (BTUs) per hour and it is fired solely by natural gas, this unit is permitexempt, in accordance with BAAQMD regulations.

In light of these changes, at the end of 2005 there was a net increase of 1 in the number of permitted and exempt emissions sources. Thus, SLAC had a total of 55 sources of air emissions listed in its facility-wide permit-to-operate, comprising 34 permitted and 21 exempt sources.

\subsubsection{Annual Update for Permit-to-Operate and Annual Title V SMOP Emissions Report}

SLAC submits two primary annual reports to the BAAQMD. One is the annual update that is prepared in response to the BAAQMD information update request for selected permitted sources, and covers the previous calendar year. The other is the Title $\mathrm{V}$ annual emissions report for all onsite sources for the SMOP and covers the period of July 1, 2004 through June 30, 2005. Following submittal of the former, SLAC received the renewal of its permit-to-operate on June 23, 2005, effective through July 1, 2006. SLAC submitted the Title V annual emissions report on time in July 2005.

Currently, the largest source of air emissions at SLAC is its BaBar detector (BAAQMD Sources S-55 and S-56, representing two separate subsystems). SLAC has operated the detector within permit conditions at all times since its startup in 1999 (Figure 4-1). However, due to steadily increasing flow rates of isobutane through the detector subsystems, a second change-of-condition application was required in 2005, as described above in Section 4.2.2.2. Isobutane is the only precursor organic compound (POC) to be used at SLAC. 


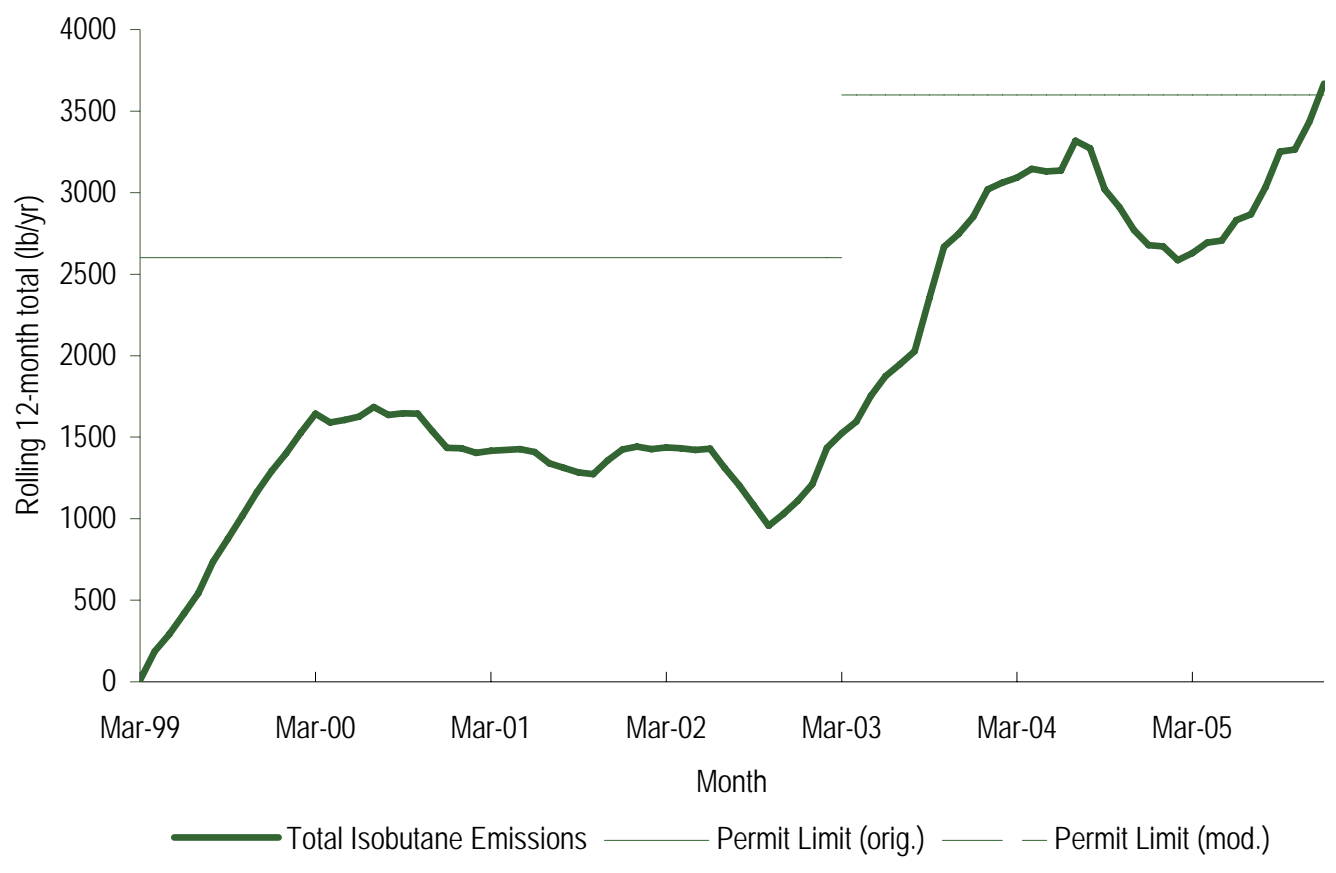

Figure 4-1 POC Emissions from BaBar (DCH-IFR/Sources S-55 and S-56)

\subsubsection{Annual Air Toxics Report}

Concurrent with BAAQMD's annual information request, facilities are also required to review the toxic substances checklist promulgated by BAAQMD to support the California Air Resources Board's Air Toxics program. If facilities emit more of a listed chemical than the applicable degree of accuracy threshold, regardless of whether the emissions originate from a permitted source, facilities have an obligation to report air toxics usage at the same time of their annual update.

SLAC submitted its annual air toxics information to BAAQMD on May 31, 2005, covering the 2004 reporting year. Air toxics emitted from permitted sources included the following:

1. H-134a (tetrafluoroethane), a Freon compound used in one of the components of the BaBar Detector: 11,017 pounds (lbs)

2. 3M FC-77 Fluorinert-brand electronic liquid (a mixture of perfluorinated compounds), used in heat exchangers for one of the components of the BaBar detector: 328 gallons (about 4,600 lbs)

3. R-22 and R-404-A, used in SLAC heating, ventilation, and air conditioning (HVAC) equipment: 708 and $78 \mathrm{lbs}$, respectively

4. 1,1,1-trichloroethane (TCA), a solvent used in the Plating Shop for degreasing parts: 40 lbs

Regarding air toxics emitted from the rest of the facility, a total of 34 air toxics were reported as being used in quantities greater than the corresponding degree of accuracy. Usage of these chemicals ranged from a low of $0.017 \mathrm{lbs}$ per year (for chromium) to a high of 20,662 lbs per year for nitric acid $\left(\mathrm{H}_{2} \mathrm{NO}_{3}\right)$. The chromium is dissolved in a one percent solution and used as a calibration standard, while $\mathrm{H}_{2} \mathrm{NO}_{3}$ is used 
extensively in the Plating Shop, along with other laboratories onsite. These quantities are used to calculate annual permit fees paid to the BAAQMD.

\subsubsection{Annual Adhesives Usage Report}

SLAC submitted its annual adhesives usage report to BAAQMD to satisfy Regulation 8-51-502.2c on April 13, 2006 (covering the 2005 reporting year) and reported using a total of 31 adhesives.

\subsubsection{Asbestos and Demolition Project Notification Program}

For projects that involve the demolition of existing structures or the management of regulated asbestoscontaining material (RACM), SLAC is required to provide advance notice to BAAQMD. During 2005, approximately 34 construction projects were evaluated for the purpose of air quality protection. Based on the project scopes and the results of pre-work asbestos surveys, asbestos/demolition notifications were formally submitted to BAAQMD for five of the 34 construction projects.

\subsubsection{National Emission Standards for Hazardous Air Pollutants}

SLAC operates four sources that are subject to 40 CFR 63, Subpart T, "National Emission Standards for Halogenated Solvent Cleaning", part of the National Emission Standards for Hazardous Air Pollutants (NESHAPs) regulations, as shown in Table 4-2. Reporting comprises an annual performance report and two semi-annual exceedance reports.

No exceedances occurred during the covered reporting periods. The four NESHAPs units were operated in accordance with their NESHAPs emissions limits during the covered reporting periods.

Table 4-2 Halogenated Solvent Cleaning Sources Subject to NESHAPS

\begin{tabular}{llll} 
Source & Source Description & Location & Halogenated Solvent Used \\
\hline S-4 & Batch vapor degreaser & Plating Shop & TCA \\
S-54 & Near-zero emission (NZE) degreaser & Plating Shop & Tetrachloroethylene \\
S-58 & Batch cleaning tank & $\begin{array}{l}\text { Electron Gun } \\
\text { Testing/Maintenance }\end{array}$ & TCA \\
& Batch cleaning tank & Plating Shop & Methylene chloride
\end{tabular}

In 2004, SLAC participated in a voluntary disclosure program with the USEPA, evaluating all uses of HAPs onsite. To document this process, a consent agreement and final order (CAFO) was later sent to SLAC, signed by the director, Jonathan Dorfan, on June 17, 2005 and submitted to USEPA.

With the successful installation of Source S-54, the Near Zero Emission (NZE) Vapor Degreaser, in 1999, SLAC realized a dramatic decrease in its emissions of chlorinated solvents from its Plating Shop, thus greatly improving its environmental performance and enhancing worker health and safety. The ten-year emissions history of chlorinated solvents from the Plating Shop is shown in Figure 4-2.

\subsubsection{Protection of Stratospheric Ozone}

No releases of stratospheric ozone-depleting substances (ODSs) occurred during 2005 that were subject to the release reporting and corrective action requirements in the ODS regulations (40 CFR 82). 
Per Executive Order 13148, “Greening the Government through Leadership in Environmental Management”, SLAC is subject to two DOE-mandated ODS-management objectives:

1. By 2005, retrofit or replace 100 percent of chillers that have greater than 150 tons of cooling capacity, were manufactured before 1984, and that use Class 1 ODS

2. By 2010, eliminate the procurement of all Class 1 ODS

SLAC completed the activities to attain the first objective in 2002, three years ahead of schedule.

Specifically, the final three pre-1984 Class 1 ODS-using chillers at SLAC were replaced in the summer of 2002.

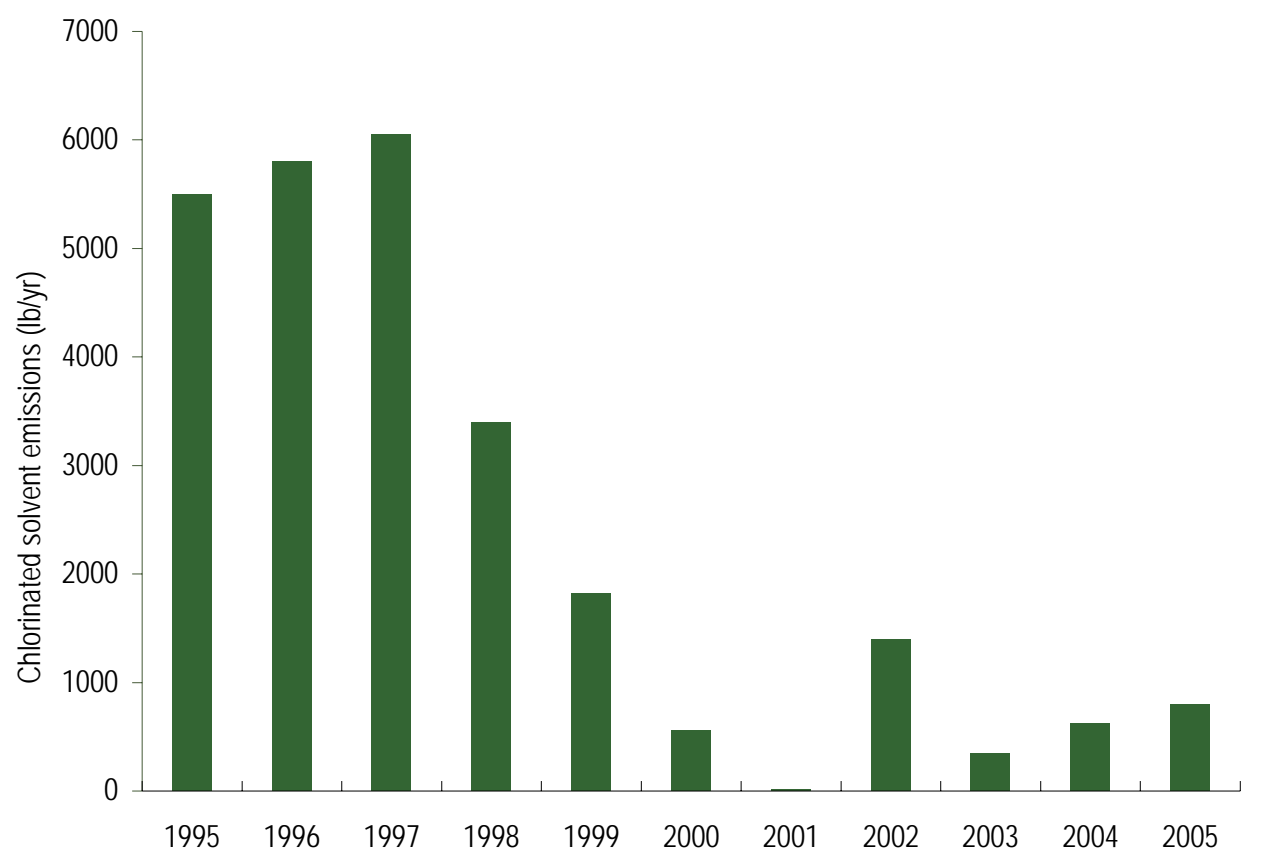

Figure 4-2 Air Emissions from Chlorinated Solvents: SLAC Plating Shop, 1995-2005

SLAC has identified the following four projects that will be necessary to achieve the second objective.

1. SSRL Building 118 Chiller Replacement

2. Halon Fire Systems Replacement (two systems)

3. Miscellaneous HVAC Equipment Replacement (approximately six small systems)

4. TCA Replacement Project, Conventional Experimental Facilities (CEF)

\subsubsection{Vehicle Fleet Management}

SLAC operates and maintains a fleet of more than 230 cars, trucks, and specialized pieces of heavy equipment to support its daily operations. Vehicles are provided by one of two federal agencies: the DOE or the General Services Administration (GSA). While the latter can be driven off site without restrictions, 
the aging DOE fleet cannot leave SLAC for insurance purposes, and so must be refueled on site at the gasoline dispensing facility (GDF) that began operating in October 2001.

The GDF is operated and managed by the Transportation Department, which is part of the CEF, and is regulated as a permitted emissions source by the BAAQMD. Records of deliveries of both gasoline and diesel are tracked and reported annually to BAAQMD. Under the conditions of SLAC's site-wide air permit, the gasoline dispensing system obtained an annual source test to ensure proper functioning. The source test was performed by a contractor in September 2005 and all results were positive. The results are transmitted automatically to both SLAC and BAAQMD by the contractor.

In addition to SLAC-owned passenger cars and trucks, portable diesel dispensing tanks are filled at the GDF and then transported throughout SLAC to refuel heavy equipment and stationary engines, such as emergency back-up generators.

The GDF provides both gasoline and diesel for SLAC vehicles. Only 1,424 gallons of gasoline were dispensed in 2005, continuing a steady decline for the fourth year in a row. In sharp contrast, however, biodiesel fuel consumption spiked at 6,940 gallons, including 4,822 gallons for May of 2005. This jump in use resulted from a three-day power outage during May. Consequently, generators were pressed into service throughout the site during the outage.

SLAC continued its efforts to replace and upgrade its vehicle fleet. In 2005, four electric vehicles were added to the SLAC GSA fleet, increasing the total number of electric vehicles to 217 (Table 4-3).

Table 4-3 Vehicle Fleet Summary

\begin{tabular}{lrr} 
Indicator & CY05 & CY04 \\
\hline Total number of vehicles on site & 227 & 224 \\
Total number of GSA vehicles & 217 & 213 \\
Total number of DOE vehicles & 8 & 11 \\
Average GSA vehicle age in years & 3 & 3 \\
Average DOE vehicle age in years & 17 & 17 \\
Average year vehicle manufactured & 2001 & 2000
\end{tabular}

At the beginning of the year SLAC operated only 11 DOE-owned vehicles. The average age of these vehicles was 17 years, and they represented the worst-polluting vehicles of SLAC's vehicle fleet. By the end of the year, SLAC had disposed of three of these aging vehicles, leaving only eight DOE trucks onsite.

Further reductions in the average age of SLAC's vehicle fleet are anticipated. As expected, each reduction brings about corresponding decreases in the associated air emissions.

\subsubsection{Greenhouse Gas Inventory and Baseline}

Sulfur hexafluoride $\left(\mathrm{SF}_{6}\right)$, the most potent greenhouse gas (GHG) known, is used at SLAC in both electrical equipment and experimental apparatus. Current policy calls for researchers to justify the use of $\mathrm{SF}_{6}$, evaluate potential alternatives, and commit to responsible management of the gas in all operations. It remains clear that $\mathrm{SF}_{6}$ is an extremely useful material, by far the most appropriate for some applications, and that research into acceptable substitutes has barely begun. Beginning in 2005 and at the request of 
ES\&H, research proposals have considered substitutes and incorporated justification for using $\mathrm{SF}_{6}$, even in minute quantities.

\subsubsection{Summary and Future Plans}

SLAC emits pollutants to the atmosphere from its operation of one-of-a-kind research and manufacturing equipment, as well as from more conventional sources such as building maintenance and vehicle fleet operation. SLAC operates its air quality management program in compliance with its established permit conditions. Until 2005, the SLAC air quality management program had operated for seven consecutive years without receiving any NOVs from regulators. Nevertheless, SLAC maintains an active program to improve its environmental performance in the air quality arena. Recent years have witnessed the following accomplishments:

- Decrease of more than 90 percent in halogenated solvent emissions from SLAC’s Plating Shop

- Replacement of three pre-1984, Class 1 ODS using chillers

- Decrease in the average age of SLAC's vehicle fleet

- Successful negotiations to obtain a Title V SMOP, which implements caps on facility-wide HAPs emissions

- Installation of new natural gas metering and instrumentation control systems at its main boilers

Future plans include the phasing out of all Class 1 ODSs, continued work on the GHG baseline/inventory survey for the facility, development and implementation of a new air emissions data management system, and further transition to a younger, more alternatively-fueled vehicle transportation fleet.

\subsection{Industrial and Sanitary Wastewater Management Program}

SLAC discharges industrial pollutants and sanitary sewage to the sewage collection system operated by the West Bay Sanitary District (WBSD). The sewage is then conveyed via the WBSD's collection system to the wastewater treatment plant operated by the South Bayside System Authority (SBSA). Much of SLAC's industrial pollutants are removed prior to discharge at such facilities as the Metal Finishing Pre-treatment Facility (MFPF) and the contained water treatment system at Cooling Tower 1701. This section describes the regulatory framework under which SLAC operates for the purpose of water quality protection, and presents the status of SLAC's water quality protection programs in 2005.

\subsubsection{Regulatory Framework}

The Federal Water Pollution Control Act, also referred to as the Clean Water Act (CWA), was enacted in 1972 to halt the degradation of our nation's waters. The CWA established the National Pollutant Discharge Elimination System, which regulates discharges of wastewater from point sources such as a publicly owned treatment work and categorically regulated industrial facilities such as electroplating shops. In 1987, the CWA was amended to include non-point source discharges such as stormwater run-off from industrial, municipal, and construction activities. The CWA is the primary driver behind the SLAC water quality protection programs.

SLAC operates its industrial and sanitary wastewater programs under two mandatory wastewater discharge permits, which are negotiated jointly with the WBSD and SBSA. These permits were renewed on April 1, 2002, and will expire on December 15, 2006, and specify monitoring programs and pollutant discharge 
limits. SLAC also has two discretionary groundwater discharge permits. One is for the existing groundwater treatment system at the Former Solvent Underground Storage Tank (FSUST), which will expire August 21, 2006. The other permit is for the dual phase extraction and treatment system at the Former Hazardous Waste Storage Area (FHWSA), which became effective October 15, 2004, and expires October 14, 2009. The FHWSA was working in an interim mode and was completed to a full-scale system at the end of CY05. SLAC also has a contractual relationship with the WBSD, which specifies the total industrial and sanitary flow allowed to be discharged. A summary of these requirements is presented in Table 4-4.

Table 4-4 Industrial and Sanitary Wastewater Monitoring Requirements

\begin{tabular}{|c|c|c|c|}
\hline Sampling Location & WBSD Permit Number & Sampling Frequency & Monitoring Parameters \\
\hline Sand Hill Road Station & WB 020401-F & Quarterly (by SBSA) & $\mathrm{Cd}, \mathrm{Cr}, \mathrm{Cu}, \mathrm{Pb}, \mathrm{Ni}, \mathrm{Ag}, \mathrm{Zn}, \mathrm{pH}$, Flow \\
\hline $\begin{array}{l}\text { Metal Finishing Pre- } \\
\text { treatment Facility }\end{array}$ & WB 020401-P & $\begin{array}{l}\text { Semiannually (by SLAC), } \\
\text { annually (by SBSA) }\end{array}$ & $\begin{array}{l}\mathrm{Cd}, \mathrm{Cr}, \mathrm{Cu}, \mathrm{Pb}, \mathrm{Ni}, \mathrm{Ag}, \mathrm{Zn}, \mathrm{pH} \text {, cyanide, } \\
\text { Flow }\end{array}$ \\
\hline FSUST & GW WB082201 & $\begin{array}{l}\text { Quarterly (determined by } \\
\text { carbon depletion pattern) }\end{array}$ & Specified organics, ${ }^{*}$ Flow \\
\hline FHWSA & GW WB041015 & Quarterly & $\begin{array}{l}\text { As, } \mathrm{Cd}, \mathrm{Cr}, \mathrm{Cu}, \mathrm{Pb}, \mathrm{Hg}, \mathrm{Ni}, \mathrm{Ag}, \mathrm{Zn} \text {, } \\
\text { Specified organics, CS2, Flow }\end{array}$ \\
\hline $\begin{array}{l}\text { Sand Hill Road and } \\
\text { three Alpine Road } \\
\text { stations (MSub, Alpine, } \\
\text { IR08) }\end{array}$ & $\begin{array}{l}\text { Contractual discharge } \\
\text { arrangement }\end{array}$ & $\begin{array}{l}\text { Flow data collected on } \\
\text { real-time basis }\end{array}$ & Flow \\
\hline
\end{tabular}

Per the permit terms, SLAC is required to submit a semi-annual self-monitoring report ${ }^{15}$ on the results of its monitoring of the MFPF, a semi-annual certification of a solvent management plan for approximately 100 solvents selected by the SBSA, and quarterly reports for discharges of treated groundwater ${ }^{16}$ and radioactivity in industrial wastewater (see Section 5.5.1).

15 Stanford Linear Accelerator Center, Environment, Safety, and Health Division, Environmental Protection Department, Semiannual Self-Monitoring Report, Mandatory Wastewater Discharge Permit WB 020401-P (EP 0507-01, 31 July 2005, submitted to Norman Domingo, Technical Services Supervisor, SBSA)

Semiannual Self-Monitoring Report, Mandatory Wastewater Discharge Permit WB 020401-P (EP 0601-01, 31 January 2006, submitted to Norman Domingo, Technical Services Supervisor, SBSA)

16 Stanford Linear Accelerator Center, Environment, Safety, and Health Division, Environmental Protection Department, Groundwater Discharge Self Monitoring Report, 1st Quarter 2005, Discretionary Groundwater Discharge Permit No. GW WB041015 (April 9, 2005, submitted to SBSA)

, Groundwater Discharge Self Monitoring Report, $2^{\text {nd }}$ Quarter 2005, Discretionary Groundwater Discharge Permit No. GW WB041015 (July 13, 2005, submitted to SBSA)

- Groundwater Discharge Self Monitoring Report, $3^{\text {rd }}$ Quarter 2005, Discretionary Groundwater Discharge Permit No. GW WB041015 (October 13, 2005, submitted to SBSA)

- Groundwater Discharge Self Monitoring Report, $4^{\text {th }}$ Quarter 2005, Discretionary Groundwater Discharge Permit No. GW WB041015 (January 12, 2006, submitted to SBSA) 
SLAC's industrial and sanitary monitoring locations are shown in Figure 4-3. SLAC's Sand Hill Road flow metering station (Sandhill FMS) is located immediately upstream of SLAC's sewer system connection to WBSD's Sand Hill Road trunk line, just to the north of the SLAC main gate. SLAC also has three flow monitoring stations (MSub, Alpine, and IR08) on the south side of the facility, which collectively monitor the flow SLAC discharges to the WBSD's Alpine Road trunk line.

Industrial and Sanitary Water Monitoring Locations

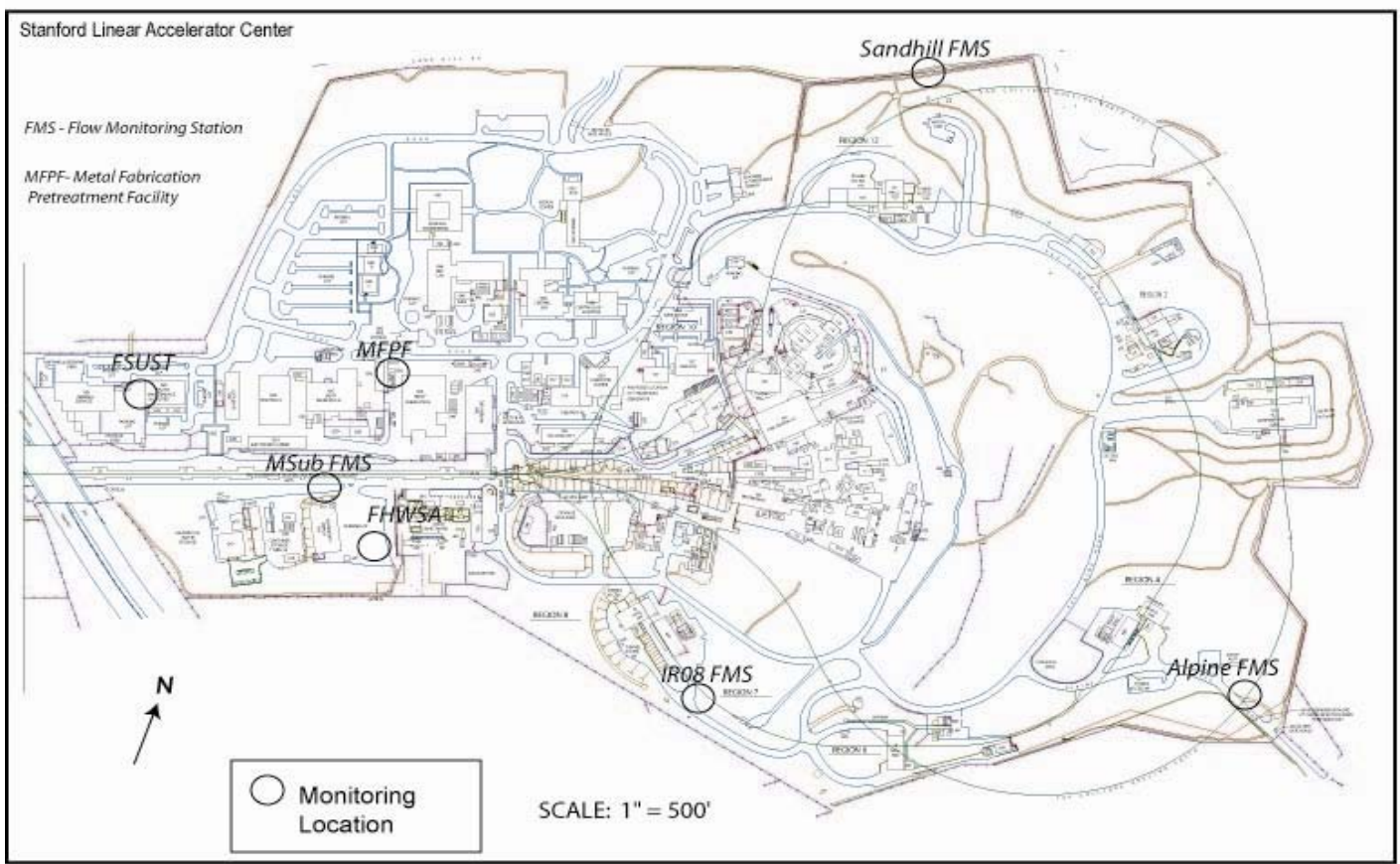

Figure 4-3 Industrial and Sanitary Wastewater Monitoring Locations

\subsubsection{Program Status}

\subsubsection{Annual Facility Enforcement Inspection}

The SBSA conducted an annual inspection of SLAC on July 29, 2005, with a follow-up meeting on August 19 , 2005. Discussion topics during the inspection focused on the proposed modifications to the sanitary

Erler \& Kalinowski, Inc, Groundwater Discharge Self Monitoring Report, 1st Quarter 2005, Discretionary Groundwater Discharge Permit No. GW WB 082201 (April 14, 2005, submitted to SBSA)

- Groundwater Discharge Self Monitoring Report, 2nd Quarter 2005, Discretionary Groundwater Discharge Permit No. GW WB 082201 (July 13, 2005, submitted to SBSA)

- Groundwater Discharge Self Monitoring Report, 3rd Quarter 2005, Discretionary Groundwater Discharge Permit No. GW WB 082201 (October 13, 2005, submitted to SBSA)

— Groundwater Discharge Self Monitoring Report, 4th Quarter 2005, Discretionary Groundwater Discharge Permit No. GW WB 082201 (January 13, 2006, submitted to SBSA) 
sewer discharge location as a result of the Safety and Operational Reliability Improvements Project and the implementation of an accidental spill prevention plan, which is part of the industrial waste permit. No NOVs were issued.

\subsubsection{Flow Monitoring Results}

Total industrial and sanitary wastewater discharge to the WBSD's regional collection system was approximately 23.7 million gallons, which equates to an average of approximately 64,900 gallons per day (gpd). The flow discharge entitlement limit for SLAC is approximately 23.5 million gallons, or 64,400 gpd. Thus, SLAC was approximately 0.8 percent over its facility-wide flow discharge limit in 2005. This was remedied with an increase in entitlement.

\subsubsection{Water Quality Monitoring Results}

A summary of the water quality results for the Sand Hill Road station is presented in Table 4-5, along with the discharge limits set forth in SLAC’s permits.

SLAC was in compliance with all seven heavy metal limits during 2005. On an annual basis, SLAC discharged from 27 percent (for lead) to 79 percent (for copper) of its permitted discharge limits, as shown in Figure 4-4.

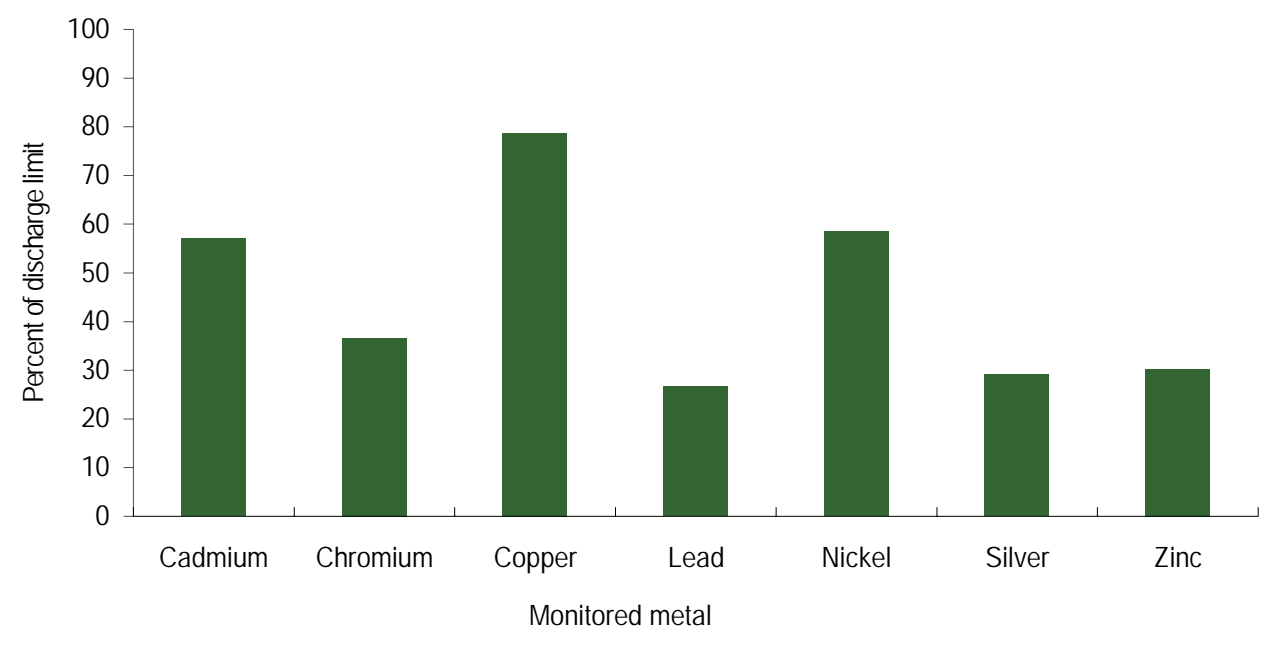

Annual average $=$ calculated average percent of discharge limit from quarterly sampling events

Figure 4-4 Water Quality at the Sand Hill Road Station 
Table 4-5 Water Quality at the Sand Hill Road Station

\begin{tabular}{|c|c|c|c|c|c|}
\hline \multirow[b]{2}{*}{ Parameter } & \multicolumn{2}{|c|}{ January 25, 2005} & \multicolumn{2}{|c|}{ April 25, 2005} & \multirow[b]{2}{*}{$\begin{array}{l}\text { Wastewater } \\
\text { Discharge } \\
\text { Limits* (ppd) }\end{array}$} \\
\hline & $\begin{array}{l}\text { SBSA } \\
\text { Monitoring } \\
\text { Results (mg/L) }\end{array}$ & $\begin{array}{l}\text { SBSA Calculated } \\
\text { Results (ppd) }\end{array}$ & $\begin{array}{l}\text { SBSA } \\
\text { Monitoring } \\
\text { Results (mg/L) }\end{array}$ & $\begin{array}{l}\text { SBSA Calculated } \\
\text { Results (ppd) }\end{array}$ & \\
\hline Flow (gpd) & 94,254 & NA & 124,565 & NA & \\
\hline Cadmium & $<0.0500$ & $<0.039304$ & $<0.0500$ & $<0.051944$ & 0.036 \\
\hline Chromium & $<0.1000$ & $<0.078608$ & $<0.1000$ & $<0.103887$ & 0.18 \\
\hline Copper & 0.1700 & 0.133633 & 0.2000 & 0.207774 & 0.13 \\
\hline Lead & $<0.1900$ & $<0.149355$ & $<0.1900$ & $<0.197386$ & 0.33 \\
\hline Nickel & $<0.1500$ & $<0.117912$ & $<0.0300$ & $<0.031166$ & 0.042 \\
\hline Silver & $<0.0150$ & $<0.011971$ & $<0.0150$ & $<0.015583$ & 0.036 \\
\hline Zinc & 0.1790 & 0.140708 & 0.3050 & 0.316856 & 0.45 \\
\hline $\mathrm{pH}^{*}$ & 8.30 & NA & 8.30 & NA & $6.0-12.5$ \\
\hline Parameter & \multicolumn{2}{|c|}{ August 10, 2005} & \multicolumn{2}{|c|}{ October 10, 2005} & \\
\hline Flow (gpd) & 57,763 & NA & 57,568 & NA & \\
\hline Cadmium & $<0.0100$ & $<0.0048$ & $<0.0100$ & $<0.0048$ & 0.036 \\
\hline Chromium & $<0.0200$ & $<0.0096$ & 0.0200 & 0.0096 & 0.18 \\
\hline Copper & 0.1100 & 0.0530 & 0.1300 & 0.0624 & 0.13 \\
\hline Lead & $<0.0400$ & $<0.0193$ & $<0.0400$ & $<0.0192$ & 0.33 \\
\hline Nickel & $<0.0300$ & $<0.0145$ & 0.0700 & 0.0336 & 0.042 \\
\hline Silver & 0.0070 & 0.0034 & 0.0100 & 0.0048 & 0.036 \\
\hline Zinc & 0.1710 & 0.0824 & 0.1610 & 0.0773 & 0.45 \\
\hline $\mathrm{pH}^{*}$ & 8.10 & NA & 8.20 & NA & $6.0-12.5$ \\
\hline
\end{tabular}

$\mathrm{NA}=$ not appllicable

ppd = pounds per day

gpd = gallons per day

1 Calculated Results in lb/day = (gal/day)(mg/l pollutant)(8.34 lb/gal)(10E-6 l/mg)

$2 \mathrm{pH}$ is regulated as Daily Maximum rather than an Annual Average Limit

* Compliance is determined by comparing the mass discharge limit with the average of the samples taken for the previous 12 months.

The analytical results for water quality samples collected at the MFPF are presented in Table 4-6, along with the discharge limits set forth in SLAC's permits. SLAC was in compliance with all seven heavy metal limits and the cyanide limit on all three sampling dates. 
Table 4-6 Water Quality at the Metal Finishing Pre-treatment Facility

\begin{tabular}{|c|c|c|c|c|c|}
\hline \multirow[b]{3}{*}{ Analytical Parameter } & \multirow{2}{*}{\multicolumn{2}{|c|}{ Discharge Limits }} & \multirow{3}{*}{$\begin{array}{l}\text { SBSA-Initiated } \\
\text { Annual Sampling } \\
\text { August } 10 \\
\\
\text { SBSA Monitoring } \\
\text { Results (mg/L) }\end{array}$} & \multicolumn{2}{|c|}{ SLAC-Initiated Semi-Annual Sampling } \\
\hline & & & & March 28 & October 11 \\
\hline & $\begin{array}{l}\text { Federal Daily } \\
\text { Maximum (mg/L) }\end{array}$ & $\begin{array}{l}\text { Federal } \\
\text { Monthly } \\
\text { Average } \\
\text { (mg/L) }\end{array}$ & & $\begin{array}{l}\text { SLAC Monitoring } \\
\text { Results (mg/L) }\end{array}$ & $\begin{array}{l}\text { SLAC Monitoring } \\
\text { Results (mg/L) }\end{array}$ \\
\hline \multicolumn{6}{|l|}{ Metals } \\
\hline Cadmium & 0.69 & 0.26 & $<0.01$ & $<0.0010$ & $<0.010$ \\
\hline Chromium & 2.77 & 1.71 & 0.080 & $<0.040$ & $<0.040$ \\
\hline Copper & 3.38 & 2.07 & 1.600 & 0.1390 & 0.2500 \\
\hline Lead & 0.69 & 0.43 & $<0.04$ & $<0.040$ & $<0.040$ \\
\hline Nickel & 3.98 & 2.38 & 0.960 & 0.0790 & 0.1300 \\
\hline Silver & 0.43 & 0.24 & 0.037 & $<0.0010$ & $<0.010$ \\
\hline Zinc & 2.61 & 1.48 & 0.102 & $<0.030$ & $<0.030$ \\
\hline \multicolumn{6}{|l|}{ Non-metals } \\
\hline Cyanide & 1.20 & 0.65 & 0.0033 & $<0.0050$ & 0.040 \\
\hline pH (unitless) & $6.0-12.5$ & NA & 8.90 & 9.22 & 9.02 \\
\hline
\end{tabular}

1 All monitoring results, except for $\mathrm{pH}$, are expressed in units of milligrams per liter (mg/L).

2 Former Total Toxic Organics (TTO) monitoring requirement was superseded by implementation of SLAC's Solvent Management Plan, which was originally submitted to SBSA on July 31, 2001

$3 \mathrm{NA}=$ not applicable

\subsubsection{Best Management Practices Implementation Results}

The Industrial Wastewater Program started initiating best management practices (BMPs) in 2004 to reduce discharge of constituents of concern to the sanitary sewer. The following were accomplished in 2005 as part of this effort:

- A quarterly sampling program for the basin water at Cooling Tower 1701 is used to evaluate the effectiveness of the containment water treatment system. This unit primarily treats rainwater that accumulates in electrical vaults and transformer containments. The treated water is then used as makeup water in Cooling Tower 1701. The sampling confirmed the unit's effectiveness. PCBs have not been detected. A summary of the results are summarized below in Table 4-7.

- The PEP II tunnel continues to be cleaned in a manner to minimize water use, thus allowing for the bagging of solids for disposal instead of solids flowing into the tunnel gutter and discharging to the sanitary sewer. Approximately 800 lbs of solids have been diverted from the sanitary sewer annually.

- As a result of analyzing mop water from the High Bay in Building 44 for metals and PCBs approximately 50 gallons of mop/spill water have been diverted from the sanitary sewer annually. 
- Two new guidelines have been posted on the web describing BMPs that are protective to the sanitary sewer for Machine and Craft shops and Wet laboratories. ${ }^{17}$

- The flushing of copper piping as part of new building construction is now being staggered to reduce daily copper loading to the sanitary sewer.

Table 4-7 Cooling Tower 1701 Basin Results

\begin{tabular}{|l|l|l|l|}
\hline Sample ID & IW-CT05-1 & IW-CT05-2 & IW-CT05-3 \\
\hline Date & $3 / 28 / 2005$ & $6 / 17 / 2005$ & $9 / 19 / 2005$ \\
\hline PCB $(\mathrm{mg} / \mathrm{L})$ & $<0.00020$ & $<0.00020$ & $<0.00020$ \\
\hline Diesel $(\mathrm{mg} / \mathrm{L})$ & $<0.050$ & $<0.050$ & $<0.050$ \\
\hline Motor Oil $(\mathrm{mg} / \mathrm{L})$ & $<0.050$ & $<0.050$ & $<0.050$ \\
\hline Mineral Oil (mg/L) & $<0.050$ & $<0.050$ & $<0.050$ \\
\hline Total Dissolved Solids $(\mathrm{mg} / \mathrm{L})$ & 1400 & 1700 & 1500 \\
\hline
\end{tabular}

\subsubsection{Summary and Future Plans}

SLAC discharges industrial and sanitary wastewater to the WBSD regional sewer collection system. These discharges originate from manufacturing locations such as SLAC's Plating Shop, heat exchange systems such as SLAC's six major cooling tower installations, and employee toilets and sinks throughout the facility.

SLAC operates its industrial and sanitary wastewater management program in compliance with established permit conditions. In 2005, SLAC operated the program for the ninth consecutive year without receiving any NOVs from program regulators. SLAC is in the process of combining the multiple permits into one site-wide permit that will include flows to both the Sand Hill and Alpine trunk lines and incorporate the groundwater treatment systems and MFPF as sub-discharges. This permit consolidation will allow SLAC to manage its industrial wastewater in a consistent manner and will better represent discharges to the sanitary sewer. In addition, SLAC plans to install additional flow meters to track flow from the Interaction Region 6 (IR-6) area before discharging to the Alpine trunk line.

\subsection{Surface Water Management Program}

There are 24 stormwater channels that leave the 426-acre SLAC site. In certain portions of the site, stormwater has the potential to come into contact with industrial activities or facilities before discharge. Such activities or facilities include metal working, outdoor storage, cooling towers, electrical equipment operation, and secondary containments.

Many of the 24 channels drain land still in its natural state, where there is no potential for stormwater to contact industrial activities occurring at the site. Some locations drain developed land or areas where

17 Stanford Linear Accelerator Center, Environment, Safety, and Health Division, Environmental Protection Department, “Industrial Water”, http://wwwgroup.slac.stanford.edu/esh/groups/ep/water/industrial/ 
stormwater can potentially come into contact with industrial activities, but the characteristics of the drainage is similar to monitored locations. Therefore, the focus of SLAC's surface water management program is on the remaining seven locations, listed below and shown in Figure 4-5.

1. IR-8 Channel (IR-8)

2. IR-6 Channel (IR-6)

3. North Adit East Channel (NAE)

4. Main Gate East Channel (MGE)

5. IR-2 North Channel (IR-2)

6. Building 81 North Channel (B81)

7. Building 15 and Building 18 combined flow (B015/B018)

\subsubsection{Regulatory Framework}

Federal regulations allow authorized states to issue general permits to regulate industrial stormwater or non-point source discharges. California is an authorized state and in 1991, the State Water Resources Control Board (SWRCB) adopted the industrial activities stormwater general permit, with the goal of reducing water pollution by regulating stormwater discharges associated with industrial activities. SLAC filed a notice of intent to comply with the general permit.

California's general permit was re-issued in 1997. SLAC adheres to the requirements of the general permit, and specifies how it adheres to requirements through its stormwater pollution prevention plan (SWPPP). ${ }^{18}$ The SWPPP has two main components: a stormwater monitoring program (SWMP) and a BMPs program. ${ }^{19}$ The SWMP presents the rationale for sampling, lists the sampling locations, and specifies the analyses to be performed. The BMPs present a list of 13 generic and site-specific practices that serve to minimize the impact on stormwater from SLAC's industrial activities (see Section 4.4.2.3).

18 Stanford Linear Accelerator Center, Environment, Safety, and Health Division, Environmental Protection and Restoration Department, SLAC Stormwater Pollution Prevention Plan (SLAC-I-7500A16M-002)

19 Stanford Linear Accelerator Center, Environment, Safety, and Health Division, Environmental Protection Department, "Stormwater", http://wwwgroup.slac.stanford.edu/esh/groups/ep/water/stormwater/ 


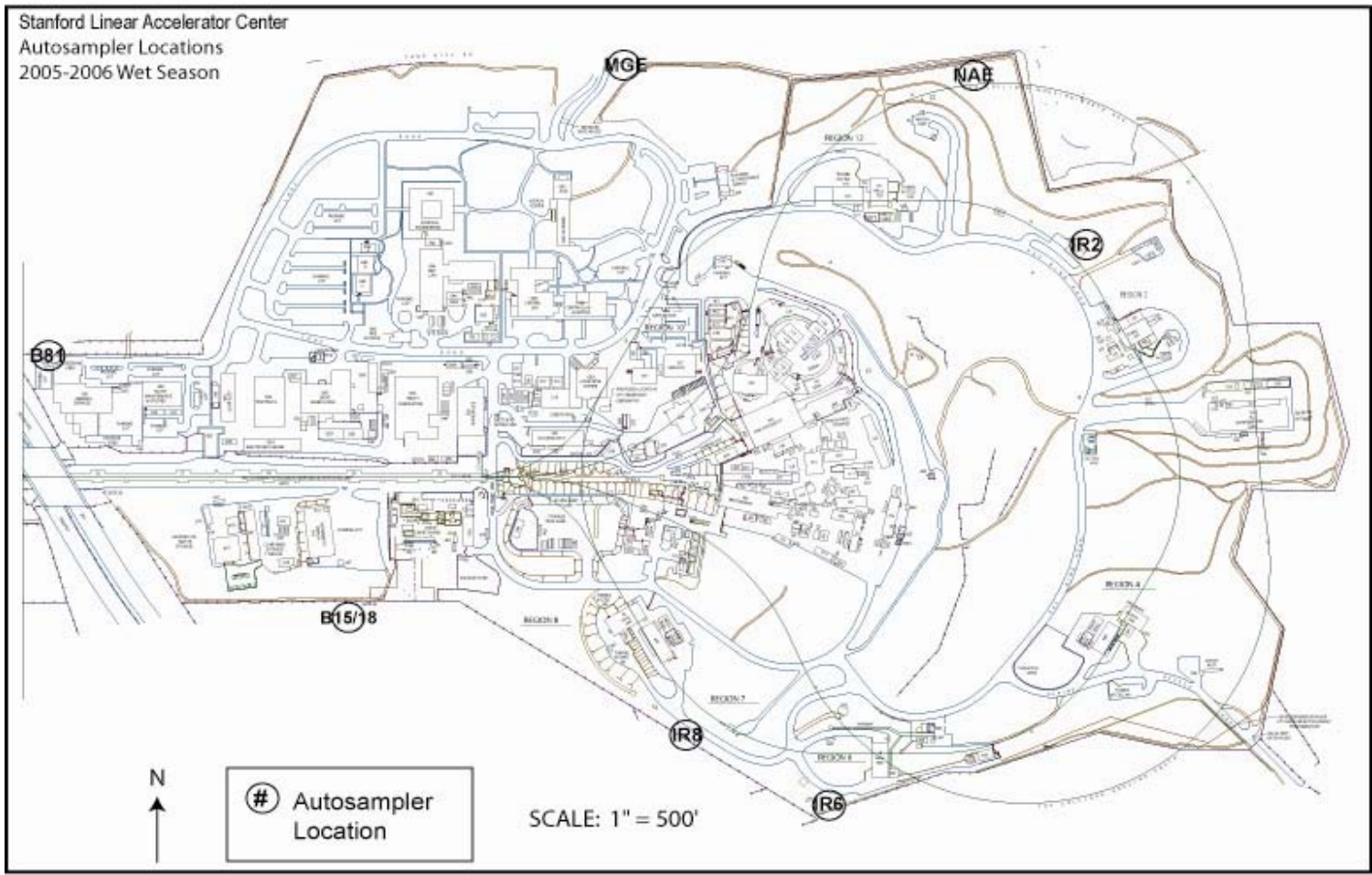

Figure 4-5 Surface Water Monitoring Locations

\subsubsection{Program Status}

\subsubsection{Annual Facility Enforcement Inspection}

Neither the Environmental Health Division of the San Mateo County Health Services Agency (SMCHSA), nor the RWQCB conducted an inspection of SLAC's surface water protection program this year.

\subsubsection{Water Quality Monitoring Results}

SLAC's SWMP incorporates all general permit sampling and analysis requirements, such as frequency (samples collected from first storm of season and one additional storm), locations (samples collected from locations where stormwater comes into contact with industrial activities), analytes (SLAC analyzes for 12 metal and nine non-metal analytes), and methodologies.

The general permit's definition of wet season runs from October 1 through May 30. This reflects SLAC's climatological conditions, as rain rarely falls during June through September. Since the general permit's definition of wet season spans two calendar years, the 2005 water quality monitoring results published in the ASER are for the 2005-2006 wet season (that is, the last three months of 2005 and the first five months of 2006). 
The general permit requires submission of an annual report on stormwater activities by July 1 , following the May 30 close of the wet season. ${ }^{20}$ SLAC met all sampling and analysis requirements in its SWMP and delivered its annual report, which includes all water quality monitoring results, to the RWQCB.

Automated samplers are located at each of the stormwater monitoring sites. The samplers are triggered by rain gauges and level sensors. Though this allows for monitoring of storm events that occur during offhours, the sensors are not always reliable, thus, three storm events that occurred during off-hours activated only some of the samplers. The remaining sample locations had to be sampled during storm events that occurred during facility operating hours.

Stormwater samples were collected at seven locations and analyzed for as many as 14 parameters. Many of the parameters that SLAC monitors have parameter benchmark values (PBVs) established by the SWRCB. ${ }^{21}$ Note that PBVs represent a threshold at which BMPs should be re-evaluated for effectiveness, not numerical discharge limits.

If a facility's stormwater monitoring results are entirely below the PBVs, by law the facility operator is entitled to a reduction in stormwater monitoring frequency. Thus, a comparison of SLAC's observed stormwater monitoring results against the PBVs is used to assess the overall effectiveness of SLAC's stormwater management program.

Table 4-8 summarizes the results and compares them to the PBVs. The majority of the analytical results (77 percent) were below the PBVs. Analytes that exceeded the PBVs were primarily specific conductance, aluminum, iron, zinc and total suspended solids (TSS). In an effort to reduce the metals and TSS levels, SLAC increased the preventative maintenance, including annual site-wide street cleaning, as discussed in the next section.

\subsubsection{Stormwater Management Improvements}

BMPs are implemented at SLAC to reduce the potential for stormwater to come into contact with industrial activities. The BMPs are one component of an environmental management system that includes planning, implementing, checking, and improving performance.

BMP and surface water program-related accomplishments during 2005 included the following:

- Improvements to the SWMP continue through programmatic changes and increased documentation

- Outreach activities which include presentations to various groups at SLAC and articles for SLAC's newsletter

- New BMP training for specific areas

- Increased preventive maintenance schedule for stormwater protection activities including annual sitewide street cleaning

- Infrastructure improvement projects: End Station A/End Station B and salvage yards - to be completed in 2007

20 Stanford Linear Accelerator Center, Environment, Safety, and Health Division, Environmental Protection Department, 2005-2006 Annual Stormwater Report (EP 0606-05, 30 June 2006, submitted to Rico Duazo, San Francisco Bay RWQCB)

21 State of California, State Water Resources Control Board, Sampling and Analysis Reduction Certification (no date), http://www.swrcb.ca.gov/stormwtr/docs/smanlrdc.doc 
Table 4-8 Water Quality Results and Comparison to Parameter Benchmark Values

\begin{tabular}{|c|c|c|c|c|c|c|c|}
\hline Analyte & Units & $\begin{array}{l}\text { Number } \\
\text { of } \\
\text { Results }\end{array}$ & $\begin{array}{l}\text { Number } \\
\text { of } \\
\text { Detects }\end{array}$ & $\begin{array}{l}\text { Maximum } \\
\text { Conc. } \\
\text { Detected }\end{array}$ & $\begin{array}{l}\text { SWRCB } \\
\text { PBV (1) }\end{array}$ & $\begin{array}{l}\text { Number of } \\
\text { Results } \\
>\text { PBV }\end{array}$ & $\begin{array}{l}\text { Percent } \\
\text { of Results } \\
>\text { PBV }\end{array}$ \\
\hline \multicolumn{8}{|l|}{ Metals } \\
\hline Aluminum & $\mathrm{mg} / \mathrm{L}$ & 14 & 14 & 1.9 & 0.75 & 7 & 50 \\
\hline Chromium & $\mathrm{mg} / \mathrm{L}$ & 1 & 1 & 0.0047 & NA & NA & NA \\
\hline Copper & $\mathrm{mg} / \mathrm{L}$ & 14 & 14 & 0.056 & $0.0636(\mathrm{H})$ & 0 & 0 \\
\hline Iron & $\mathrm{mg} / \mathrm{L}$ & 14 & 14 & 3.9 & 1 & 7 & 50 \\
\hline Lead & $\mathrm{mg} / \mathrm{L}$ & 14 & 14 & 0.033 & $0.0816(\mathrm{H})$ & 0 & 0 \\
\hline Manganese & $\mathrm{mg} / \mathrm{L}$ & 1 & 1 & 0.13 & 1 & 0 & 0 \\
\hline Zinc & $\mathrm{mg} / \mathrm{L}$ & 13 & 13 & 0.66 & $0.117(\mathrm{H})$ & 9 & 69 \\
\hline \multicolumn{8}{|l|}{ Non-Metals } \\
\hline TSS & $\mathrm{mg} / \mathrm{L}$ & 14 & 14 & 470 & 100 & 7 & 50 \\
\hline TOC & $\mathrm{mg} / \mathrm{L}$ & 14 & 14 & 74 & 110 & 0 & 0 \\
\hline $\mathrm{pH}$ & $\mathrm{SU}$ & 14 & 14 & 7.9 & $6-9$ & 0 & 0 \\
\hline Turbidity & NTU & 14 & 14 & 260 & NA & $N A$ & $\mathrm{NA}$ \\
\hline $\mathrm{SC}$ & $\mu \mathrm{s}$ & 14 & 14 & 3200 & 200 & 12 & 86 \\
\hline PCBs & $\mathrm{mg} / \mathrm{L}$ & 14 & 1 & 0.00043 & 0.000477 & 0 & 0 \\
\hline Radioactivity & $\mathrm{pCi} / \mathrm{L}$ & 14 & 0 & $\mathrm{ND}(2)$ & NA & NA & $\mathrm{NA}$ \\
\hline Total & & 169 & 142 & & & 42 & $33(3)$ \\
\hline
\end{tabular}

Notes:

1 SWRCB parameter benchmark values are available at www.swrcb.ca.gov/stormwtr/docs/smanlrdc.doc. Metal PBVs shown are on a total metal basis. $(\mathrm{H})$ signifies that this is a hardness dependant benchmark. The PBV shown for PCBs is for Aroclor-1260. SWRCB PBVs have not been set for chromium, molybdenum, radioactivity (tritium, gamma), or turbidity. SLAC may choose to develop benchmarks for site specific conditions.

2 The analyte was not detected in any of the samples for which it was analyzed.

3 Determined by the total number of results greater than PBVs for those analytes for which PBVs are available.

$\mathrm{NA}=$ Not available

$\mathrm{ND}=$ Not detected

\subsubsection{Summary and Future Plans}

SLAC discharges stormwater with the potential to come into contact with industrial activities. An extensive monitoring program is in place at the seven discharge locations where past sampling results indicate the greatest potential exists for industrial contact. During the 2005-2006 wet season, SLAC met all requirements of its monitoring plan.

In 2005, SLAC operated its surface water program for the thirteenth consecutive year without receiving any NOVs from program regulators. When analytical results from the 2005-2006 wet season were compared with the PBVs, over 77 percent of all the parameter results were below the benchmarks. SLAC continued to actively pursue several BMP-related performance improvements during the year.

\subsection{Hazardous Materials Management}

SLAC uses hazardous materials as part of its experimental programs in high-energy physics and synchrotron radiation. For instance, isobutane and the refrigerant H-134a are used to create detector 
atmospheres with the appropriate physical and chemical properties to aid in detecting subatomic particles. In addition, SLAC uses hazardous materials in the manufacturing and maintenance of accelerator devices. Examples of hazardous materials managed at SLAC include

- Cryogens

- Flammable gases

- Compressed gases

- Acids and bases

- Solvents

- Adhesives

- Paints and epoxies

- Metals

\subsubsection{Regulatory Framework}

The regulatory framework for hazardous materials regulations, especially in California, has historically been a complex and overlapping web of statutes and regulations. Some of the most important regulatory drivers at the federal level include the Resource Conservation and Recovery Act (RCRA), the CERCLA, also commonly referred to as Superfund, its successor, the Superfund Amendments and Reauthorization Act (SARA), and the Toxic Substances Control Act (TSCA).

Important drivers at the state level generally date back to the mid-1980s and include hazardous materials business plans (HMBP), the California Accidental Release Prevention Program (CalARP), the underground and aboveground storage tank programs, and the pollution prevention and waste minimization program.

In general, the implementing agency for hazardous materials regulation in California is the CUPA. The CUPA is tasked with overseeing SLAC's hazardous materials management programs is the SMCHSA, Environmental Health Division. A CUPA has broad enforcement responsibilities in the following six hazardous material subject areas:

1. Aboveground storage tanks/spill prevention control and countermeasures (AST/SPCC programs)

2. Hazardous materials business plan

3. California Accidental Release Prevention

4. Uniform Fire Code (UFC) hazardous materials issues

5. Underground storage tanks (USTs)

6. Pollution prevention and waste minimization

\subsubsection{Program Status}

Discussed in the following sections are the status of SLAC's current programs related to hazardous materials management, including its hazardous materials business plan, toxics release inventory (TRI), and CalARP programs. Also discussed are SLAC's AST program and its PCBs management program under the TSCA. 


\subsubsection{Annual Facility Enforcement Inspection}

The CUPA performed facility-enforcement inspections October 25-26, with a close-out meeting November 8, 2005. The HMBP review resulted in comments on minor changes within the HMBP and noted that the next submittal will utilize uniform documents (Unidocs) and the CMS system. CUPA was particularly impressed with the CMS mapping system being developed, but stressed that this tool must be kept updated to be useful.

\subsubsection{Hazardous Materials Business Plan Program}

The Emergency Planning and Community-Right-to-Know Act (EPCRA) was passed in 1986 as Title III of the SARA. SARA established requirements for emergency planning, notification, and reporting. In California, the requirements of SARA Title III are incorporated into the state's Hazardous Materials Release Response Plan and Inventory Law, more commonly referred to as the HMBP program.

For the 2005 reporting year, SLAC updated its HMBP and submitted it to the CUPA on April 4, 2006. The HMBP includes a list of all hazardous materials present at SLAC in amounts exceeding the state's aggregate threshold quantities ( 55 gallons for liquids, 500 lbs for solids, and 200 cubic feet for compressed gases) on a building-by-building basis. The plan also includes the SLAC Consolidated Chemical

Contingency Plan. ${ }^{22}$ This plan combines the emergency response requirements for the following programs:

- Hazardous materials business plan

- Hazardous waste contingency plan

- Spill prevention control and countermeasure plan

- Risk management plan

This was the first year that the HMBP was submitted electronically through the Unidocs system utilizing the maps and chemical information developed as part of the CMS. The plans for the future include utilizing more of the Unidocs functionality and developing additional program elements to ensure the accuracy of the chemical inventory and maps.

\subsubsection{Toxics Release Inventory Program}

Under Executive Order 13148, “Greening the Government through Leadership in Environmental Management”, the DOE requires its facilities to comply with the Toxic Chemical Release Reporting and Community Right-to-Know requirements (40 CFR 312), more commonly referred to as the toxics release inventory (TRI) program. SLAC annually provides the appropriate information to meet these program requirements to the DOE. Submittals go to the DOE SSO, which provides the information to DOE headquarters. The information from all DOE facilities is then rolled up and reported to the USEPA.

Of the more than 400 listed TRI chemicals, only two, lead and copper, are reported at SLAC in excess of their respective regulatory threshold criteria. As a result, SLAC prepared release inventory forms for lead and copper and submitted them to the DOE SSO on June 27, 2005, in advance of the July 1, 2005, deadline. 


\subsubsection{California Accidental Release Prevention Program}

SLAC submitted its CalARP registration information to the CUPA on March 3, 1998. The original registration information was amended on May 15, 1998. The net result was that SLAC registered under the CalARP program for the "CalARP Table 3" substances nitric acid and potassium cyanide.

CalARP program regulations for Table 3 substances state that the county is required to make a determination whether a risk management plan (RMP) is required of SLAC for the CalARP-regulated substances SLAC is managing. In August 2004, SLAC received a letter from the CUPA instructing SLAC to update its chemical inventory information to determine whether SLAC had any regulated chemicals in excess of the CalARP thresholds. Only one chemical was found: potassium cyanide, which is used only in the Plating Shop complex.

Accordingly, the CUPA determined that an RMP would be necessary. By law, the CUPA is required to give SLAC a minimum of 12 months, and a maximum of 36, to submit the RMP. SLAC procured a contractor to prepare an RMP. A draft RMP was submitted to SLAC in September 2005. Based on extensive review of this document and evaluation of the scenarios created, SLAC directed its contractor to expand the scope of the document and perform a detailed process hazard assessment (PHA), as well as offsite consequence analysis (OCA), in order to complete the RMP in mid-2006.

\subsubsection{Aboveground Storage Tank Program}

ASTs are regulated under the authority of the CWA and California's Aboveground Petroleum Storage Act. A listing of ASTs containing petroleum at SLAC during 2005 is presented in Table 4-9. All petroleum tanks at SLAC are constructed of steel. Each tank is either double-walled or has a cinder-block or poured-concrete containment basin surrounding the tank base.

Table 4-9 Aboveground Petroleum Tanks

\begin{tabular}{lllr} 
Petroleum Product & Property Control Number & Location & Capacity (gallons) \\
\hline Diesel & 20501 & B023 Central Utility & 10,000 \\
Diesel & 20502 & B037 Old Boiler Building & 3,700 \\
Diesel & 19683 & B112 Master Substation & 2,000 \\
Gas/Diesel & 21443 & B035 Vehicle Refueling Station & $1,500 / 500$ \\
${ }^{*}$ Mineral Oil & 19659 & Mobile Transformer Oil Tank & 1,000 \\
${ }^{*}$ Castrol Oil & 19596 & B020 North Damping Ring & 516 \\
Diesel & NA & B082 Fire Station & 500 \\
Diesel & NA & B505A Generator Fueling & 500 \\
Diesel & NA & B007 MCC Generator Fueling & 500 \\
*Mineral Oil & NA & B062 NLC "8-pack" & 440 \\
*Mineral Oil & 19595 & B021 South Damping Ring & 260 \\
*Mineral Oil & 18902 & B044 Klystron Test Lab & 250 \\
Diesel & Unmarked & B756 SLD Generator Fueling & 250 \\
* These tanks are used only for short-term storage & &
\end{tabular}


A spill prevention, control, and countermeasures (SPCC) plan is required by 40 CFR 112 for all petroleumcontaining ASTs greater than 660 gallons in size. The SLAC SPCC plan remains up to date and is available on line. ${ }^{23}$

SLAC did not have any USTs in operation during 2005. All USTs previously in operation have been removed.

\subsubsection{Toxic Substances Control Act Program}

The objective of the TSCA is to minimize the exposure of humans and the environment to chemicals introduced by the manufacturing, processing, and commercial distribution sectors. One portion of TSCA regulates equipment filled with oil or other dielectric fluids that contain PCBs.

TSCA regulations are administered by the USEPA. No USEPA inspections regarding TSCA were conducted at SLAC during 2005.

At the end of 2005, 101 transformers were in service at SLAC. Transformers with concentrations greater than 50 parts per million (ppm) but less than $500 \mathrm{ppm}$ are defined by TSCA as PCB-contaminated transformers. Of the 101 transformers in service at SLAC, only 12 are PCB-contaminated. SLAC has no PCB transformers (transformers with concentrations of PCB greater than 500 ppm).

The total quantity of PCBs contained in the 101 transformers currently in service is approximately 24 lbs. Two new, non-PCB transformers were acquired during 2005.

\subsubsection{Chemical Management System}

In 2004, SLAC officially selected Haas tcm as its CMS contractor. Haas has also supported the safe decommissioning of bulk tanks and gas cylinders. This is done by providing electronic cataloguing, ordering, order tracking, data tracking, material safety data sheets management, electronic invoicing, cost reporting, and ES\&H reporting to SLAC. Haas provides all sourcing, purchasing, expediting, and Tier 2 vendor management support for all non-radioactive chemicals and gases used by SLAC.

As part of the start-up process, over 90 SLAC users were formally trained in the system in 2005 and the entire SLAC stores chemical inventory was transferred to the Haas hub. Through the streamlining and centralization of the chemical supply chain, SLAC has removed the need to stockpile or order excess chemicals. Users are comfortable ordering only what they need. As a result there are few unused chemicals at SLAC.

\subsection{Waste Minimization and Management}

During the course of its research operations, SLAC generates a variety of waste streams, including hazardous waste, non-hazardous industrial waste, and municipal solid waste, and scrap metal.

23 Stanford Linear Accelerator Center, Environment, Safety, and Health Division, Environmental Protection Department, Spill Prevention, Control, and Countermeasures Plan (SLAC-I-750-0A16M001), https://www-internal.slac.stanford.edu/esh/documents_internal/SPCC.pdf 
Whenever practicable, SLAC actively practices the pollution prevention hierarchy with respect to each of these waste streams:

- First, reduce waste and prevent pollution at the source through process changes, substitutions, and work practices

- Second, reduce waste and prevent pollution by reusing or recycling materials

- Third, reduce waste and prevent pollution by using appropriate control technologies

- Finally, after exhausting the first three approaches, exercise proper disposal

The following performance measures in the operating contract between the DOE and Stanford University reflect the importance that both parties place on waste minimization: ${ }^{24}$

- SLAC will reduce its generation of hazardous waste from routine operations by 65 percent by the year 2005, on a graded scale, using 1993 as the baseline year

- SLAC will recycle 50 percent of its municipal solid waste by the year 2005 on a graded scale

\subsubsection{Waste Minimization Accomplishments}

SLAC has achieved both of its waste minimization goals since the year 2000.

SLAC continues to make progress in reducing hazardous waste generated from routine operations, as shown in Figure 4-6. For 2005, SLAC reduced generation of hazardous waste from routine operations by 69 percent from the 1993 baseline. The goal for FY05 was to achieve a 65 percent reduction in routine hazardous waste relative to the 1993 baseline. SLAC did not generate significant hazardous waste during one quarter of FY05 due to a temporary halting of operations that resulted from a Type A accident. The 69 percent reduction is based on the three quarters of the year corrected for a full year of operation. Without this correction, the hazardous waste reduction would have been 77 percent but would not have reflected a full year of operation.

24 Stanford Linear Accelerator Center, Environment, Safety, and Health Division, "ISEMS: Performance Measures”, http://www-group.slac.stanford.edu/esh/general/isems/perfmeas/ 


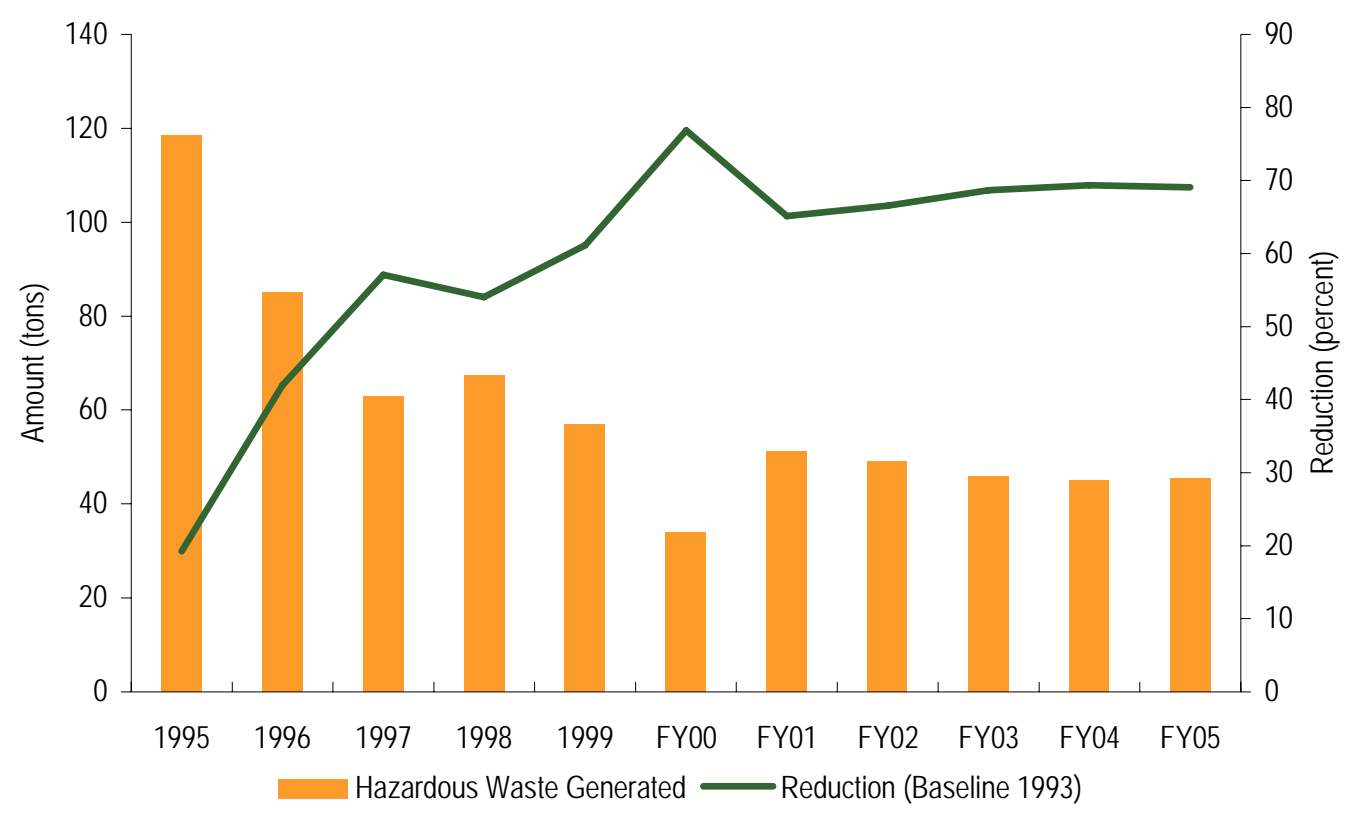

Figure 4-6 Hazardous Waste Generation, 1995-2005

SLAC's progress in recycling its municipal solid waste is shown in Figure 4-7. For 2005, SLAC recycled 52 percent of its municipal solid waste. The goal for FY05 was to achieve 50 percent recycling. The waste generated and percent recycling reflect a full year of operation; these activities were not affected by the Type A accident.

The term municipal solid waste refers to the following waste streams generated at SLAC:

- Beverage containers (glass, aluminum, plastic)

- Paper (white paper, mixed paper)

- Cardboard

- Wood

- Scrap metal

- Garden/landscaping waste

- Construction debris (asphalt, concrete, and soils)

- Trash not otherwise sorted at the source and placed into dumpsters 


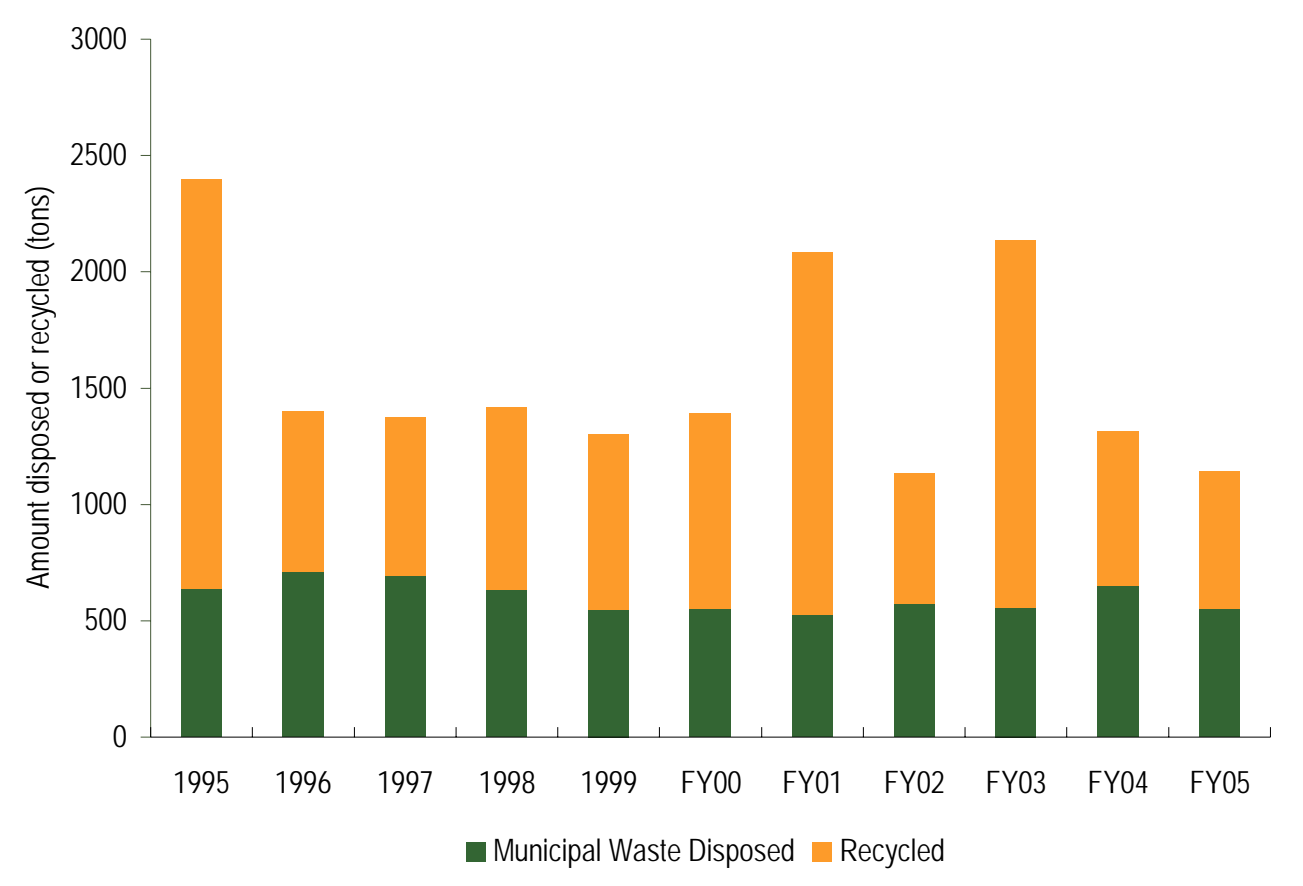

Figure 4-7 Municipal Solid Waste Recycling, 1995-2005

Waste minimization and pollution prevention projects initiated during the last ten years and continuing during 2005 are listed in Table 4-10.

In addition to the projects below, SLAC has been continuing to perform process waste assessments and pollution prevention projects to reduce the use of toxic materials, to conserve resources, and to prevent pollution in a technically and economically feasible manner for the future. Assessments and projects are in the following areas:

- Investigated the feasibility of taking waste concrete blocks and creating rubble for reuse in road bed construction projects. When concrete is not associated with radiological control areas, on-site or offsite reuse of concrete rubble for road bed is an attractive option to off-site disposal because of the potential to reduce off-site transportation costs.

- Reviewed SLAC's inventory and generation of electronic waste and investigated options for improved reuse and recycling of waste materials as a measure to ensure there is no misuse of hazardous materials in overseas markets.

\subsubsection{Hazardous Waste Management}

The RCRA provided cradle-to-grave authority to regulate hazardous wastes, from their generation to their ultimate disposal. Regulation is through a system of record keeping, permitting, monitoring, and reporting. 
Table 4-10 Waste Minimization and Pollution Prevention Projects

\begin{tabular}{|c|c|c|}
\hline Name/Description & $\begin{array}{l}\text { Year } \\
\text { Initiated }\end{array}$ & Waste Reduction/Pollution Prevention Result \\
\hline $\begin{array}{l}\text { Reduction of plating bath } \\
\text { filter usage by more } \\
\text { closely monitoring filter } \\
\text { pressure drop and } \\
\text { performance }\end{array}$ & 1995 & Reduced waste by a volume by 1655 -gallon drums per year \\
\hline $\begin{array}{l}\text { Reducing hazardous waste } \\
\text { through better waste } \\
\text { management - using } \\
\text { reuse and on- and off-site } \\
\text { recycling measures }\end{array}$ & 1995 & $\begin{array}{l}\text { Approximately } 205 \text { tons of waste disposal avoided from } 1997 \text { to } \\
2004\end{array}$ \\
\hline $\begin{array}{l}\text { Reducing wastes from } \\
\text { spent alkali and acid baths } \\
\text { in metal finishing } \\
\text { operations by reuse and } \\
\text { treatment }\end{array}$ & 1996 & 1,000 to 5,000 gallons annually \\
\hline $\begin{array}{l}\text { Scrap copper reused in } \\
\text { metal finishing operations } \\
\text { as plating bath anodes }\end{array}$ & 1996 & Reuse varies with production needs \\
\hline $\begin{array}{l}\text { Increased reuse of stock } \\
\text { metal through electric } \\
\text { discharge machining } \\
\text { operations }\end{array}$ & 1996 & $\begin{array}{l}\text { Improved fabrication technique reduces scrap metal - no } \\
\text { quantitative results tracked due to variations in production }\end{array}$ \\
\hline $\begin{array}{l}\text { PEP II waste reduction } \\
\text { promoted through reuse of } \\
\text { materials and equipment at } \\
\text { SLAC or at off-site facilities }\end{array}$ & 1998 & $\begin{array}{l}\text { Approximately } 1,000 \text { tons of concrete blocks reused at an off-site } \\
\text { location }\end{array}$ \\
\hline $\begin{array}{l}\text { Processing unit to reduce } \\
\text { stormwater waste handling } \\
\text { by removing PCBs } \\
\text { contamination }\end{array}$ & 1999 & $\begin{array}{l}\text { Approximately } 60,000 \text { gallons of stormwater reused in cooling } \\
\text { towers annually }\end{array}$ \\
\hline $\begin{array}{l}\text { Implementation of a site- } \\
\text { wide recycling program for } \\
\text { paper, cardboard, and } \\
\text { beverage cans/bottles }\end{array}$ & 1999 & Improved paper and cardboard recycling by over 30 tons per year \\
\hline $\begin{array}{l}\text { Reduction of ferric chloride } \\
\text { and filter cake in the } \\
\text { treatment of rinse waters } \\
\text { from metal finishing } \\
\text { operations }\end{array}$ & 2002 & $\begin{array}{l}\text { As of } 2004 \text {, SLAC reduced generation of hazardous waste (filter } \\
\text { cake) by an average of } 49 \text { percent over a three year period relative } \\
\text { to } 1998 \text { and per gallon of rinse water treated }\end{array}$ \\
\hline $\begin{array}{l}\text { Off-site recycling program } \\
\text { for laser printer and ink jet } \\
\text { cartridges }\end{array}$ & 2002 & $\begin{array}{l}\text { Program for off-site recycling of spent laser printer and ink jet } \\
\text { cartridges - recycled } 342 \text { cartridges in FY05 and vendor } \\
\text { contributed \$1 per recycled cartridge to charity }\end{array}$ \\
\hline $\begin{array}{l}\text { Transportation pollution } \\
\text { prevention program }\end{array}$ & 2003 & $\begin{array}{l}\text { SLAC became the first DOE Office of Science facility to order and } \\
\text { dispense only Bio-diesel } 20 \text { for all its diesel applications. Also, } 25 \\
\text { electric powered vehicles are in use. Three old DOE-owned motor } \\
\text { vehicles were replaced with GSA alternative fuel vehicles. }\end{array}$ \\
\hline
\end{tabular}


Table 4-10 Waste Minimization and Pollution Prevention Projects (Continued)

\begin{tabular}{lll} 
Name/Description & $\begin{array}{l}\text { Year } \\
\text { Initiated }\end{array}$ & Waste Reduction/Pollution Prevention Result \\
\hline $\begin{array}{l}\text { Reduction of equipment } \\
\text { using class I ozone- } \\
\text { depleting substances }\end{array}$ & 2003 & $\begin{array}{l}\text { Phased out } 3 \text { chillers (pre-1984, over 150 ton cooling capacity } \\
\text { each) that used Class I ODS }\end{array}$ \\
\hline
\end{tabular}

(Class I ODS)

Two-mile klystron gallery

lighting upgrade

Chemical Management
Service (CMS)
Water Conservation
Development of EMS
Objectives and Targets
Incorporating pollution
prevention initiatives into
the Linear Coherent Light
Source Project

2003 SLAC completed a two phase project to reduce energy usage and pollution by replacing lower-efficiency lighting system with a highefficiency one in the 2-mile linear accelerator saving over 4.4 million kilowatt-hours of electricity per year, reducing greenhouse gases generated from electricity generation, and reducing mercury usage.

2003 The CMS program is fully implemented. Through streamlining the chemical supply chain has removed the need to order excess chemicals.

2004 A pilot project is in progress to conserve water through the use of waterless urinals.

2005 EMS Objectives and Targets were developed to help further integrate pollution prevention into SLAC day-to-day activities

2005 A number of environmental initiatives have been included in the LCLS Project while it is in the design and construction phase procurement of recycled material content products, soil reuse, radioactive materials reuse, pollution prevention measures to prevent soil and water contamination from lead, construction measures to prevent soil erosion and stormwater pollution

The primary objective of RCRA was to protect human health and the environment. A secondary objective was to conserve valuable material and energy resources by promoting beneficial solid waste management, resource recovery, and resource conservation systems.

The USEPA has delegated authority to the state of California for implementing the RCRA program. In turn, the state has delegated its authority for certain aspects of hazardous waste program oversight to CUPAs; the SMCHSA, Environmental Health Division serves as the CUPA tasked with overseeing SLAC's hazardous waste management.

\subsubsection{Program Status/Annual Facility Enforcement Inspection}

SLAC is a hazardous waste generator. SLAC does not have a RCRA Part B permit that would allow it to treat hazardous waste, store it on site, and/or dispose of it on site (that is, a treatment, storage, and disposal facility [TSD] permit) under the federal-level RCRA regulations. SLAC does have permits to treat a few RCRA-exempt and non-RCRA (that is, California-only) hazardous waste streams (refer to Section 4.6.2.3 regarding the state-level tiered permit program).

In November 2005, an inspection of SLAC's hazardous waste generation program was conducted by the CUPA. No violations of hazardous waste control regulations were found. The Waste Management Group was cited for a BMP for its implementation of procedures to inspect the trucks and the driver's licensing of the transportation contractor as a measure to ensure safe transport of waste loads. 


\subsubsection{Hazardous Waste Generation and Tracking}

SLAC utilizes a self-developed, site-specific computerized hazardous waste tracking system (WTS). Hazardous waste containers are tracked from the time they are issued to the generator to eventual disposal off-site. The WTS includes fields that generate information for the biennial SARA Title III and TSCA PCB annual reports.

SLAC categorizes the hazardous wastes it generates into the following categories:

- Hazardous wastes from routine laboratory operations

- Hazardous wastes considered to be TSCA-regulated waste

- Hazardous wastes resulting from remediation and/or cleanup/stabilization projects

Hazardous wastes regulated by the TSCA at SLAC result from two sources: removal of old electrical equipment containing PCBs and construction projects containing asbestos. TSCA wastes result from the phasing-out of these chemicals from use at SLAC. SLAC's progress in reducing the quantities of TSCA waste from these sources is shown in Figure 4-8. Specifically, during FY05, SLAC achieved a 99 percent reduction in its TSCA waste generation compared with a 1990 baseline.

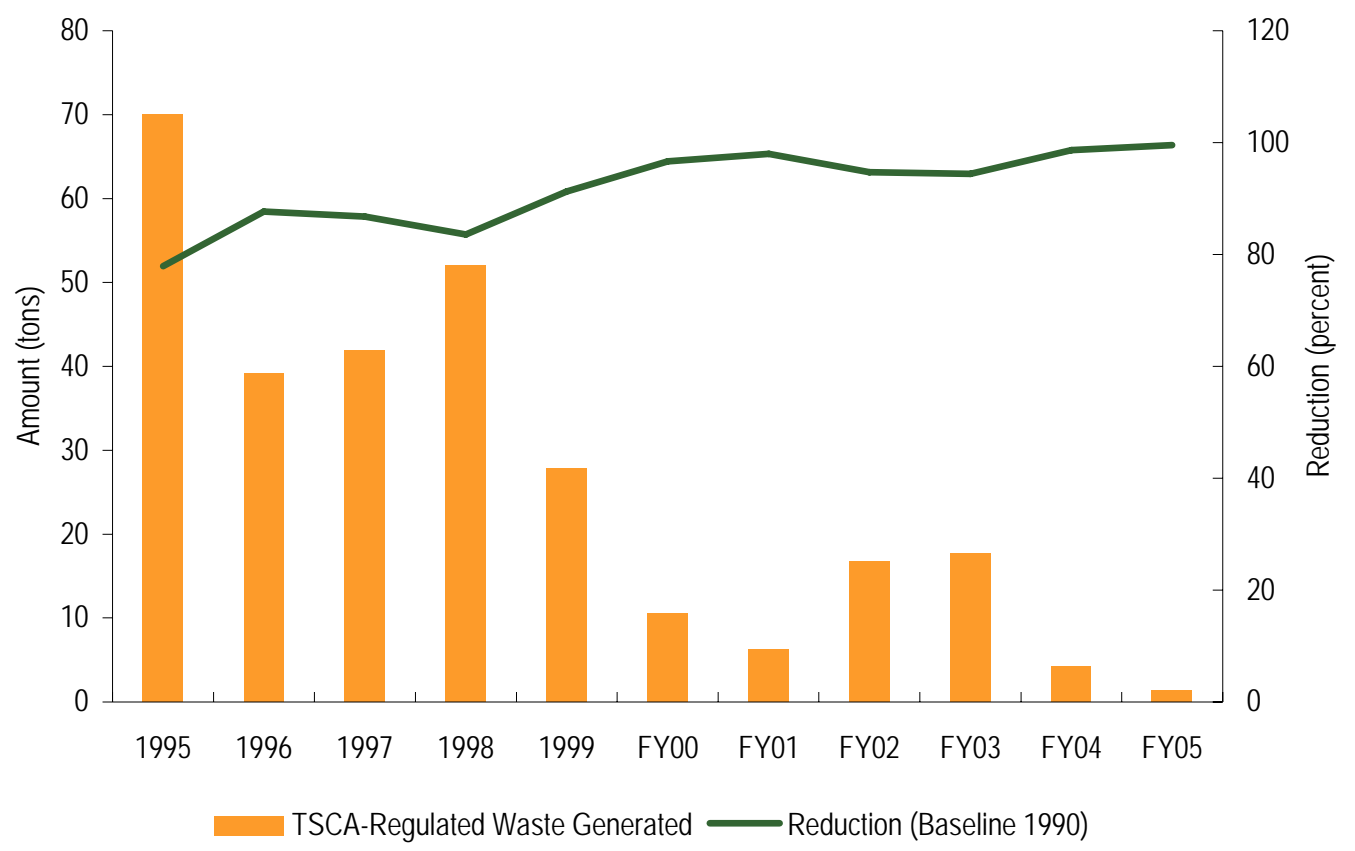

Figure 4-8 TSCA-Regulated Hazardous Waste, 1995-2005

Remediation wastes result from cleanup of soil and groundwater contaminated by historical management practices or accidental spills. Common remediation wastes at SLAC include metal- and PCB-contaminated soils. Annual quantities of remedial waste generated vary based on projects scheduled for any given year. For a discussion of SLAC's environmental restoration programs that result in the generation of remediation wastes, see Chapter 6. 
SLAC's hazardous waste generation rates have been reduced through a combination of waste minimization and pollution prevention techniques, including the following:

- Reducing generation of excess chemicals through CMS

- Converting empty metal containers and drums to scrap metal

- Exchanging chemicals with other users

- Reclassifying waste streams to reduce hazardous waste volumes

- Reusing chemicals

- Returning unused material back to the vendor or manufacturer

- Sending electrical equipment off site for reuse by other organizations

SLAC expects to continue to make progress in reducing the generation of hazardous waste from routine laboratory operations, although in much smaller increments than was previously the case. Additionally, the generation of TSCA and remediation wastes will decrease as SLAC continues to phase out its use of PCBs, removes soils impacted with PCBs, and removes asbestos-containing materials.

\subsubsection{Hazardous Waste Treatment: Tiered Permitting Program}

The five tiers of California hazardous waste permits, presented in order of decreasing regulation, are called full permit, standard permit, permit by rule, conditional authorization, and conditional exemption. SLAC operates a total of six hazardous waste treatment units, five under permit by rule and one under conditional authorization. These units were authorized to treat listed or characteristic hazardous wastes. The various units and tiered permit level are summarized in Table 4-11.

Table 4-11 Hazardous Waste Treatment Units Subject to Tiered Permitting

\begin{tabular}{lll} 
Tiered Permit Level & Unit Number & Location/Description \\
\hline Permit by rule & Unit 1A & Cyanide Treatment Tanks \\
Permit by rule & Unit 1B & Metal Finishing Pre-treatment Facility \\
Permit by rule & Unit 1C & Batch Hazardous Waste Treatment Tank \\
Permit by rule & Unit 2 & Metal Finishing Pre-treatment Facility - Sludge Dryer \\
Conditional authorization & Unit 4 & Groundwater Treatment System at the FSUST \\
Permit by rule & Unit 5 & Groundwater Treatment System at the FHWSA
\end{tabular}

The CUPA last inspected the tiered permitting program at SLAC in November 2005. The program was found to be in compliance, with no violations noted.

Based on correspondence with the California Department of Toxic Substances Control (DTSC), the original MFPF (Unit 1) was not fully authorized because of the cyanide treatment operations, which SLAC had included in the original MFPF permit. As a result, SLAC split out the original MFPF into the above units (1A, 1B, and 1C) to more clearly demark the treatment operations of the MFPF. SLAC is awaiting inspection of these units by the DTSC to affirm that Tiered Permit requirements are being met for the Cyanide Treatment Tanks (Unit 1A). 


\subsubsection{Non-hazardous Waste Management}

Non-hazardous waste can be grouped into non-hazardous industrial waste and municipal solid waste.

\subsubsection{Non-hazardous Industrial Waste Management}

In addition to its hazardous waste management program, SLAC also operates various projects that involve disposal of non-hazardous waste called here non-hazardous industrial or regulated waste. SLAC's WM Group manages industrial waste resulting from SLAC's laboratory and remediation operations that, while not classified as hazardous, is not sufficiently "clean" to be disposed of in a municipal or sanitary solid waste landfill. Examples of industrial wastes include soils contaminated with low levels of petroleum hydrocarbons, PCBs or metals such that qualify as non-hazardous but are not acceptable to municipal landfills. In California, industrial wastes are generally termed Class 2 wastes, since they are specifically required to be sent to what are known as Class 2 landfills (these provide an intermediate level of protection to the environment between Class 1, hazardous waste landfills and Class 3, municipal solid waste landfills).

\subsubsection{Municipal Solid Waste Management}

SLAC's CEF Department operates a municipal solid waste program that collects a variety of recyclable materials as well as regular dumpster refuse. SLAC's Property Control Department operates a salvage operation that sells metal and other industrial recyclables (construction materials, for example, concrete, clean soils, asphalt, wood) and equipment for their cash value. SLAC integrates the results of its metal salvage operations when reporting data about its municipal solid waste program.

A site-wide program that recycles white paper, mixed paper, beverage containers (glass, aluminum, and plastic), cardboard, and scrap wood has been fully operational for more than 10 years. Collection stations are strategically distributed around the site with each station incorporating anywhere from one to dozen green containers. Dumpsters for cardboard collection are strategically place around the site and a specific location is provided for waste wood. Scrap metal is collected and construction materials from building demolition and rehabilitation projects are also recycled. The contributions of the various waste streams being recycled are shown in Figure 4-9.

\subsubsection{Other Waste Management Activities}

SLAC generates a small quantity of low-level radioactive waste every year; this waste stream is discussed in Chapter 5.

SLAC generates a small quantity of medical waste generated by the on-site Medical Department. In California, the state Medical Waste Management Act requires proper storage, treatment, and disposal of medical waste. The state program is administered by the California Department of Health Services. 


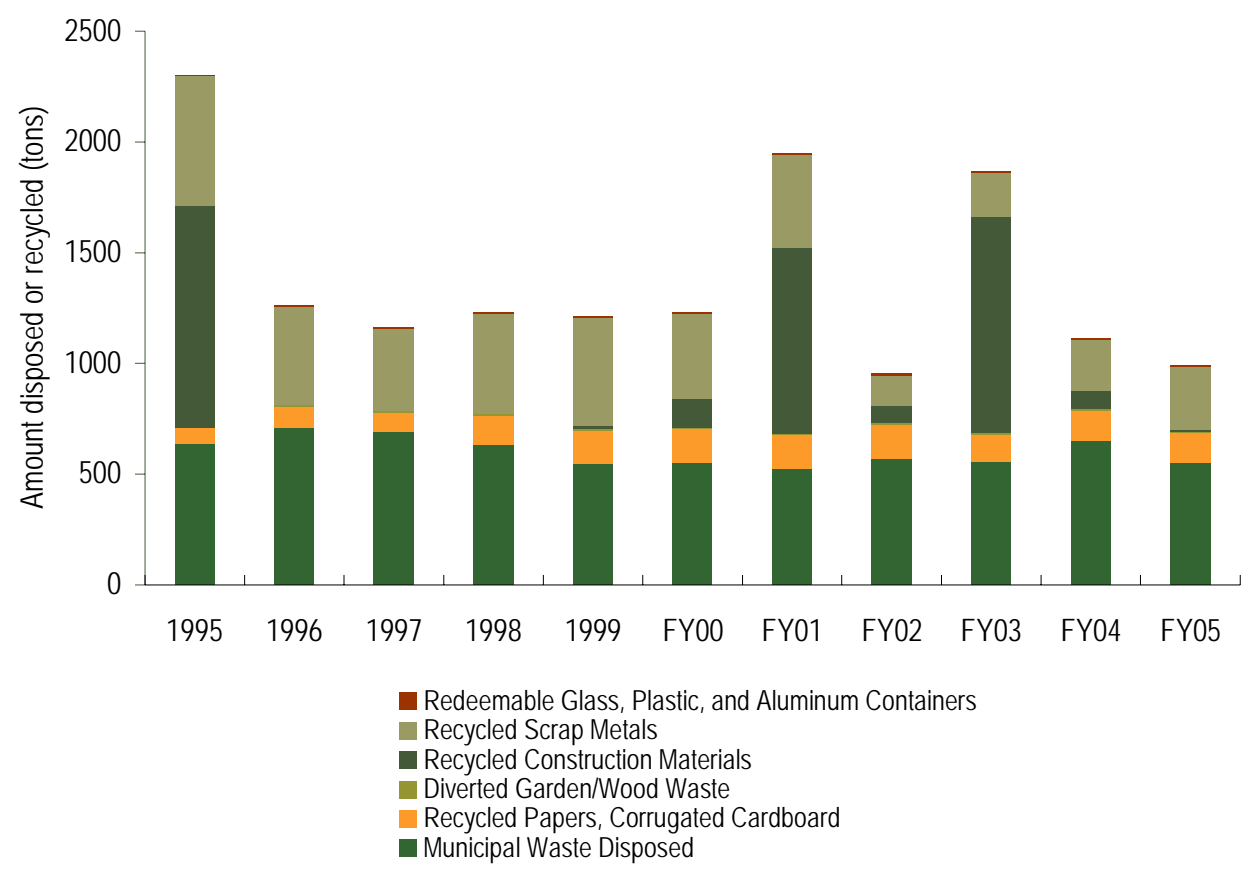

Figure 4-9 Municipal Solid Waste Recycling and Disposal, 1995-2005

\subsection{Environmental Planning}

SLAC's scientific and support facilities were constructed under a clearly conceived planning framework established in the site's original general development plan (1961) and master plan (1966). For nearly four decades, SLAC facilities expanded within this original framework, but over the years, many small support and storage buildings and more parking demands have crowded the core research areas and obscured the original circulation plan. To meet the challenges of constructing major new projects in this constricted and environmentally sensitive location, SLAC employs two primary tools: National Environmental Policy Act (NEPA) analyses on a project-by-project basis, and conformance with SLAC's long-range development plan (LRDP). ${ }^{25}$

\subsubsection{SLAC Long Range Development Plan}

In December 2002, SLAC published its LRDP, the result of both SLAC's LRDP Working Committee and the professional land use, environmental, and campus planners from the Stanford University Architect and Planning Office. The LRDP was revised in June 2003.

25 Stanford University Architect/Planning Office, Stanford Linear Accelerator Center Long Range Development Plan (December 2002, revised June 2003), http://wwwgroup.slac.stanford.edu/bsd/SLAC_LRDP_final.pdf 
The LRDP encourages the gradual replacement of small, outdated structures with more efficient and wellplanned development. The plan includes a series of diagrams that overlay planned structures and circulation systems with environmental constraints to intelligently guide the location of future projects. Environmental factors considered in developing the plan include the following:

- Geology and seismicity

- Topography

- Sedimentation and erosion potential

- Hazardous materials

- Considerations of site locations relative to sensitive receptors

- Flooding and wetlands

- Habitat and species protection

- The visual character of SLAC

\subsubsection{National Environmental Policy Act}

SLAC developed its NEPA program in 1992. It is administered by SLAC's Operations Directorate, with staff from the EP Department providing environmental resources input and document review as requested. Under this program, proposed actions are reviewed to evaluate environmental effects of the federal undertaking including alternatives. If so, the Operations Directorate works in conjunction with DOE to determine which of the following three categories of NEPA documentation, presented in increasing order of complexity, is required:

- Categorical exclusion (CX)

- Environmental assessment (EA)

- Environmental impact statement (EIS)

Aspects that must be considered when scoping and preparing NEPA documentation commonly include potential increases in air emissions or hazardous materials usage; impacts on wetlands, sensitive species, and critical habitats; and increases in water consumption and wastewater discharge.

SLAC prepared NEPA documentation for five construction projects during 2005, listed in Table 4-12. Since all the projects were relatively minor in scope and environmental impact, all required only the CX documentation. A total of five CXs were prepared to cover all the projects. Completed NEPA documents are forwarded to DOE/SSO for review and approval. 
Table 4-12 NEPA Documentation Prepared during 2005

\begin{tabular}{|c|c|c|c|c|c|}
\hline Project Name & Project ID & Project Year & Document ID & $\begin{array}{l}\text { Document } \\
\text { Type }\end{array}$ & Date \\
\hline $\begin{array}{l}\text { Storm Drain Improvement \& Const. } \\
\text { of Covered Parking-Upper Salvage } \\
\text { Yard }\end{array}$ & 030114 & 2006 & SS-SC-0503 & $C X$ & $6 / 23 / 2005$ \\
\hline $\begin{array}{l}\text { Remodeling of Building } 751 \\
\text { Mezzanine }\end{array}$ & 5545 & 2005 & SS-SC-0502 & $\mathrm{CX}$ & $6 / 23 / 2005$ \\
\hline Region 6 Drainage Alpine Road & 030115 & 2006 & SS-SC-0504 & $C X$ & $6 / 23 / 2005$ \\
\hline $\begin{array}{l}\text { Glast Operations Facility-Building } \\
084\end{array}$ & 5650 & 2006 & SS-SC-0601 & $\mathrm{CX}$ & $10 / 28 / 2005$ \\
\hline Expansion of the Director's Office & 5565 & 2006 & SS-SC-0603 & $C X$ & $1 / 5 / 2006^{*}$ \\
\hline
\end{tabular}





\section{Environmental Radiological Program}

\subsection{Introduction}

All members of the public receive radiation doses from natural background radiation and from an assortment of human activities. This chapter describes sources of radiation and radioactivity at SLAC and provides an overview of how SLAC's Environmental Radiological Program assesses direct radiation and radioactivity in water, air, and soil for the purpose of determining the potential radiation dose to the public and impacts to the environment.

The dose that members of the public receive due to SLAC operations is a small fraction of the dose received from natural background radiation. As in past years, in 2005, the potential radiation dose to the public and the radiation-related impacts to the environment from SLAC operations were significantly below all regulatory limits.

\subsection{Sources of Radiation and Radioactivity}

The linear accelerator at SLAC is encased in a concrete tunnel 25 feet beneath the surface of the ground. Through this underground tunnel, particles are accelerated to nearly the speed of light.

Some particles strike accelerator components during the acceleration process. When that happens, the decelerating particles may emit secondary radiation in the form of high-energy photons and neutrons. At SLAC, direct radiation is the radiation that is present whenever particles are accelerated, but that ceases as soon as power to the accelerator is terminated. Direct radiation is mainly due to the secondary photon and neutron radiation emitted when high-energy particles are decelerated.

Both the particles being accelerated and secondary radiation may also make the substances they strike become radioactive. Table 5-1 lists the predominant radioactive elements produced in water or air and their half-lives.

Facilities at SLAC are designed to meet all applicable safety and environmental requirements. Nearly all the direct radiation is stopped by the combined shielding on the accelerator structure and the earth that surrounds the accelerator tunnel. SLAC monitors the small fraction of photons and neutrons that pass through the accelerator components, through the surrounding earth, to reach areas outside of the accelerator. This monitoring is described in Section 5.3.

SLAC also assesses, measures, and reports on radioactivity as required by its policies and by state or federal regulations. Sections 5.4 through 5.6 and 5.9 describe SLAC's programs to assess and control radioactivity that can be released into the environment. All known releases of radioactive materials are included in the tables in those sections. 
Table 5-1 Activation Products in Water or Air

\begin{tabular}{lll} 
Radioactive Element & Half-life & Primarily Produced In \\
\hline Oxygen $\left({ }^{15} \mathrm{O}\right)$ & 123.0 seconds & Water or air \\
Nitrogen $\left({ }^{13 \mathrm{~N}}\right)$ & 10.0 minutes & Air \\
Carbon $\left.{ }^{11} \mathrm{C}\right)$ & 20.3 minutes & Water or air \\
Argon $\left({ }^{41} \mathrm{Ar}\right)$ & 1.8 hours & Air \\
Beryllium $\left({ }^{7} \mathrm{Be}\right)$ & 53.6 days & Water \\
Hydrogen $\left({ }^{3 \mathrm{H}}\right)$ & 12.3 years & Water
\end{tabular}

\subsection{Monitoring for Direct Radiation}

DOE standards (10 CFR 835) require SLAC to demonstrate that radiation and radioactivity from SLAC did not cause any member of the public to receive a radiation dose greater than 100 millirems (mrem, a unit used to quantify radiation dose to humans) during the year. ${ }^{26}$ In 2005, the maximum dose that could have been received by a member of the public due to direct radiation from SLAC was approximately less than 0.2 mrem ( $2.0 \times 10^{-3}$ milli Sievert (mSV)), or 0.2 percent of the 100 mrem regulatory limit. This maximally exposed individual (MEI) is located near Sand Hill Road, approximately 650 meters (m) (2,133 feet) northeast of the intersection of Sand Hill and Whiskey Hill Road.

During 2005, SLAC measured direct radiation at 39 locations to determine the potential radiation dose to a member of the public. Readings from dosimeters used to measure radiation were recorded each calendar quarter. Landauer Incorporated, accredited by the DOE's Laboratory Accreditation Program (DOELAP) and National Voluntary Laboratory Accreditation Program (NVLAP) as a dosimeter supplier, provided and processed the dosimeters. Results from these dosimeters were also used to calculate the collective dose to the population that lives within 80 kilometers $(\mathrm{km})$ (50 miles) of SLAC.

Section 5.8 and Table 5-6 summarize annual doses from both direct radiation and airborne radioactivity and show how those doses compare with those from natural background radiation.

\subsection{Assessment of Airborne Radioactivity}

USEPA regulations (40 CFR 61) enacted under the Clean Air Act and DOE Order 5400.5 require SLAC to demonstrate that airborne radioactivity released did not cause any member of the public to receive a dose greater than 10 mrem during the year. In 2005, the maximum dose that could have been received by a member of the public (business offices in the Portola Valley Training Center on the south east side of SLAC) due to airborne radioactivity from SLAC was $0.04 \mathrm{mrem}\left(4.0 \times 10^{-4} \mathrm{mSv}\right)$, or less than one percent of the 10 mrem regulatory limit.

26 United States Department of Energy, DOE Order 5400.5, "Radiation Protection of the Public and the Environment”, http://www.directives.doe.gov/pdfs/doe/doetext/oldord/5400/054005c2.html 
SLAC files an annual report that describes the possible sources, types, and quantities of airborne radioactivity released into the atmosphere. ${ }^{27}$ As detailed in that report, the released airborne radioactivity was calculated, based on conservative information about accelerator operations in 2005. Table 5-2 summarizes the released radioactivity, showing the quantities in curies (Ci). Potential doses to members of the public due to the released radioactivity were determined using USEPA software (CAP88). In addition to providing information on maximum individual doses, SLAC also assessed and reported the collective dose to the population that lives within $80 \mathrm{~km}$ (50 miles) of SLAC.

Table 5-2 and Table 5-6, as well as Section 5.8, provide a summary of the results and information on how the maximum possible doses compare with natural background radiation.

Table 5-2 Airborne Radioactivity Released in 2005

\begin{tabular}{llr} 
Category & Radioactive Element & Activity $(\mathrm{Ci})$ \\
\hline Tritium & Hydrogen $\left({ }^{3} \mathrm{H}\right)$ & $\mathrm{n} / \mathrm{a}$ \\
Krypton-85 & Krypton $\left({ }^{85 \mathrm{Kr}}\right)$ & $\mathrm{n} / \mathrm{a}$ \\
Noble gases $\left(\mathrm{T}_{1 / 2}<40\right.$ days $)$ & Argon $\left({ }^{41} \mathrm{Ar}\right)$ & 0.8 \\
Short-lived activation products $\left(\mathrm{T}_{1 / 2}<3 \mathrm{hr}\right)$ & Oxygen $\left({ }^{15} \mathrm{O}\right)$ & 19.6 \\
& Nitrogen $\left({ }^{13 \mathrm{~N}}\right)$ & 36.7 \\
& Carbon $\left({ }^{11} \mathrm{C}\right)$ & 3.9 \\
Other activation products $\left(\mathrm{T}_{1 / 2}>3 \mathrm{hr}\right)$ & $\mathrm{n} / \mathrm{a}$ & $\mathrm{n} / \mathrm{a}$ \\
Total radioiodine & $\mathrm{n} / \mathrm{a}$ & $\mathrm{n} / \mathrm{a}$ \\
Total radiostrontium & $\mathrm{n} / \mathrm{a}$ & $\mathrm{n} / \mathrm{a}$ \\
Total uranium & $\mathrm{n} / \mathrm{a}$ & $\mathrm{n} / \mathrm{a}$ \\
Plutonium & $\mathrm{n} / \mathrm{a}$ & $\mathrm{n} / \mathrm{a}$ \\
Other actinides & $\mathrm{n} / \mathrm{a}$ & $\mathrm{n} / \mathrm{a}$ \\
Total & & 61 \\
$\mathrm{n} / \mathrm{a}-$ not applicable & & \\
$\mathrm{T}_{1 / 2}-$ half life & &
\end{tabular}

\subsection{Assessment of Radioactivity in Water}

Three types of water are monitored for radioactivity at SLAC: industrial wastewater, stormwater, and groundwater. This section summarizes the 2005 monitoring and results for each water type.

\subsubsection{Industrial Wastewater}

Federal and state regulations (10 CFR 20.2003 and 17 CCR 30253) limit the radioactivity in industrial wastewater that SLAC releases to the sanitary sewer system. In 2005, SLAC releases totaled less than 0.03 percent of the applicable limits.

27 Stanford Linear Accelerator Center, Environment, Safety, and Health Division. Radiation Protection Department, Radionuclide Air Emissions Annual Report - CY2005 (May 2006) 
Although most of the cooling water or other water present in the accelerator does not contain radioactivity other than what is naturally present, some of the water becomes activated by radiation from the accelerator (see Section 5.2). Routine operations require SLAC to drain accelerator cooling systems from time to time. Cooling water, as well as ground- and stormwater that enters the accelerator housing, is disposed of as part of SLAC's industrial wastewater. Thus a small fraction of SLAC's wastewater volume contains radioactivity.

Throughout the year, SLAC sampled and analyzed wastewater at about 30 discharge points. Total activity released during CY05 is summarized in Table 5-3.

Table 5-3 Radioactivity in Wastewater Released in 2005

\begin{tabular}{llrr} 
Category & Radioactive Element & Activity (Ci) & $\begin{array}{r}\text { Annual } \\
\text { Release } \\
\text { Limit (Ci) }\end{array}$ \\
\hline Tritium & Hydrogen $\left({ }^{3} \mathrm{H}\right)$ & $1.4 \times 10^{-3}$ & 5 \\
Activation products $\left(\mathrm{T}_{1 / 2}>3 \mathrm{hr}\right)$ & Sodium $\left({ }^{22} \mathrm{Na}\right)$ & 0 & $1^{*}$ \\
& Beryllium $\left({ }^{7} \mathrm{Be}\right)$ & 0 & \\
Total radioiodine & $\mathrm{n} / \mathrm{a}$ & 0 & 0 \\
Total radiostrontium & $\mathrm{n} / \mathrm{a}$ & 0 \\
Total uranium & $\mathrm{n} / \mathrm{a}$ & 0 \\
Plutonium & $\mathrm{n} / \mathrm{a}$ & 0 \\
Other actinides & $\mathrm{n} / \mathrm{a}$ & 0 \\
* Combined. Excluding $3 \mathrm{H}$ (for which there is a 5 Ci annual limit), there is a 1 Ci limit for the \\
combined activity of all radioactive elements released during the calendar year \\
n/a - not applicable
\end{tabular}

Table 5-4 summarizes the historical results of wastewater monitoring for CY1995 through 2005. The final column of the table compares the radioactivity discharged by SLAC into the sanitary sewer with the annual limit for such discharges set by federal and state regulation.

Each year, the quantities and types of radioactivity in wastewater discharged depend on past accelerator operations and on details of wastewater handling.

Throughout 2005, SLAC reported the results of wastewater monitoring to the SBSA at the end of each calendar quarter. ${ }^{28}$

28 Stanford Linear Accelerator Center, Environment, Safety, and Health Division, Radiation Protection Department, Radioactivity in Industrial Wastewater for the Period 1 January 2005 to 31 March 2005, ,for the Period 2 April 2005 to 30 June 2005, for the Period 3 July 2005 to 30 September 2005, and for the Period 4 October to 31 December 2005 
Table 5-4 Summary of Radioactivity in SLAC Wastewater, 1995-2005

\begin{tabular}{|c|c|c|c|}
\hline Year & Radioactive Element & Activity (Ci) & $\begin{array}{l}\text { Percentage of } \\
\text { Annual Limit }\end{array}$ \\
\hline 1995 & Hydrogen $\left({ }^{3} \mathrm{H}\right)$ & $1.1 \times 10^{-2}$ & 0.2 \\
\hline 1996 & Hydrogen $\left({ }^{3} \mathrm{H}\right)$ & $3.4 \times 10^{-1}$ & 6.8 \\
\hline 1997 & Hydrogen $\left({ }^{3} \mathrm{H}\right)$ & $2.2 \times 10^{-2}$ & 0.5 \\
\hline 1998 & Hydrogen $\left({ }^{3} \mathrm{H}\right)$ & $7.2 \times 10^{-2}$ & 1.4 \\
\hline 1999 & Hydrogen $\left({ }^{3} \mathrm{H}\right)$ & $7.1 \times 10^{-3}$ & 0.1 \\
\hline 2000 & Hydrogen $\left({ }^{3} \mathrm{H}\right)$ & $2.4 \times 10^{-3}$ & 0.05 \\
\hline 2001 & Hydrogen $\left({ }^{3} \mathrm{H}\right)$ & $2.1 \times 10^{-3}$ & 0.04 \\
\hline \multirow[t]{3}{*}{2002} & Hydrogen $\left({ }^{3} \mathrm{H}\right)$ & $2.4 \times 10^{-2}$ & 0.5 \\
\hline & Sodium ( ${ }^{22 \mathrm{Na})}$ & $5.1 \times 10^{-5}$ & $1.4^{*}$ \\
\hline & Beryllium ( ${ }^{7} \mathrm{Be}$ ) & $1.4 \times 10^{-2}$ & \\
\hline 2003 & Hydrogen $\left({ }^{3} \mathrm{H}\right)$ & $4.1 \times 10^{-4}$ & 0.008 \\
\hline 2004 & Hydrogen $\left({ }^{3} \mathrm{H}\right)$ & $2.0 \times 10^{-2}$ & 0.4 \\
\hline 2005 & Hydrogen $\left({ }^{3} \mathrm{H}\right)$ & $1.4 \times 10^{-3}$ & 0.03 \\
\hline
\end{tabular}

\subsubsection{Stormwater}

The program for monitoring stormwater is described in Section 4.4 of this report. In 2005 (and in all previous years), no radioactivity above background was found in any stormwater sample.

SLAC reported the results of the 2005-2006 stormwater monitoring (including checks for radioactivity) to the RWQCB. ${ }^{29}$

\subsubsection{Groundwater}

Throughout 2005, SLAC analyzed water samples from monitoring wells for the presence of radioactivity each time the wells were sampled under the groundwater monitoring plan described in Chapter 6 of this report. With the exception of the four monitoring wells listed in Table 5-5 below, no radioactivity above natural background was detected in any of the groundwater samples.

The detected concentrations of tritium in the water samples summarized in Table 5-5 were below federal and state limits set for tritium in drinking water (20,000 picoCuire/liter (pCi/L)) under 22 CCR 64443 and 40 CFR 141.66). In addition, groundwater is not used at SLAC for any purposes because of its very low well yields. Even if there was an adequate supply of groundwater available at SLAC, it could not be used as drinking water due to the high content of total dissolved solids.

29 Stanford Linear Accelerator Center, Environment, Safety, and Health Division, Environmental Protection Department, 2005-2006 Annual Report for Stormwater Discharges Associated with Industrial Activities (June 30, 2006, submitted to Rico Duazo, San Francisco Bay RWQCB) 
Table 5-5 Summary of Tritium Concentrations Measured in Monitoring Wells in 2005

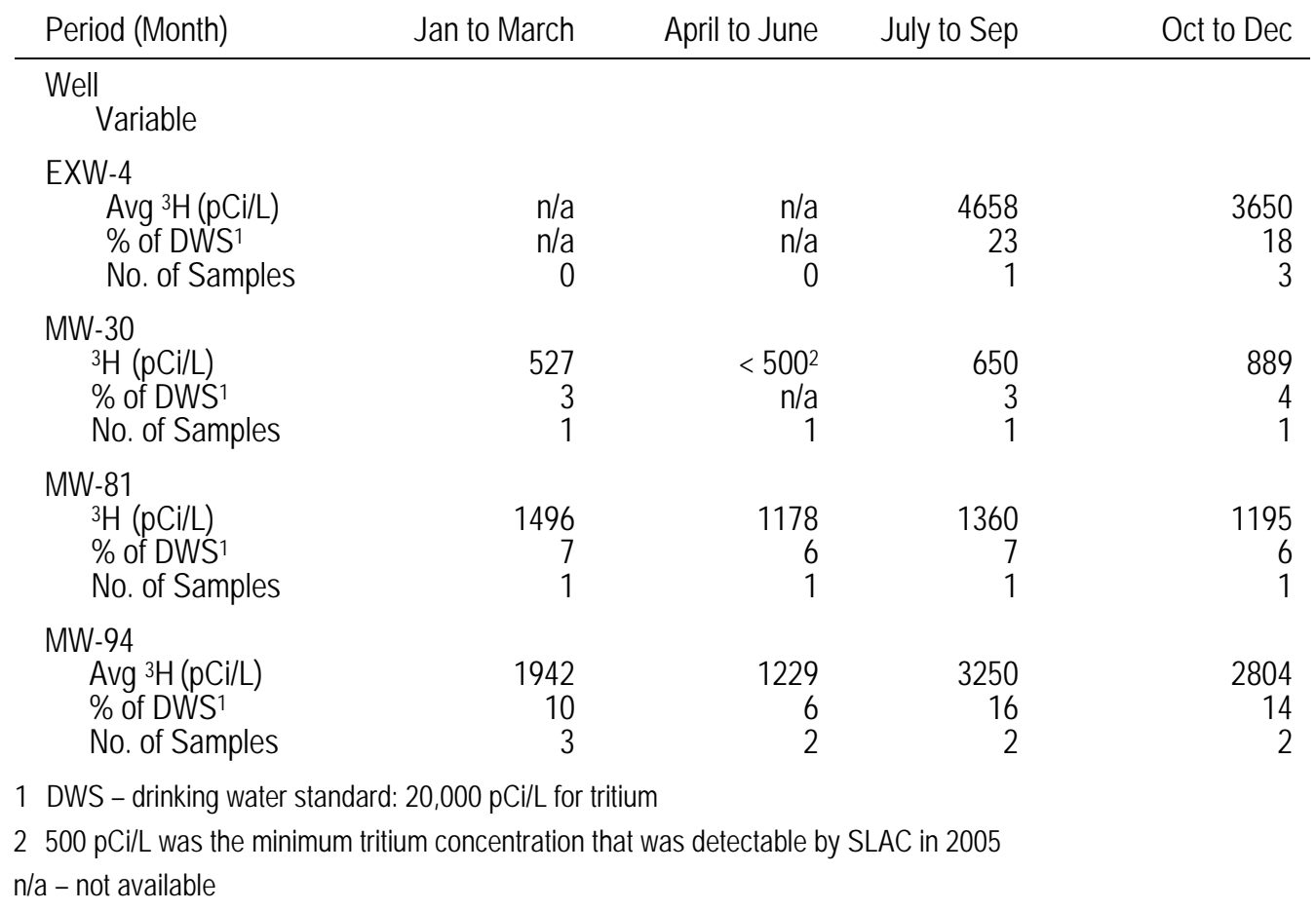

\subsection{Assessment of Radioactivity in Soil}

Throughout 2005, SLAC sampled and analyzed soil for projects involving soil excavation on the SLAC site. No soil samples were found to contain radioactivity in excess of natural background near accelerator operations.

\subsection{Release of Property Containing Residual Radioactive Material}

Throughout 2005, all property, real and personal, exposed to any process that could cause it to become radioactive was surveyed for radioactivity before it was permitted to be removed from SLAC. Property that had any detectable radioactivity was identified as radioactive, and was either retained for appropriate reuse on site or was disposed of as radioactive waste. Therefore property releases do not add to the potential public dose. Material which did not have detectable radioactivity was not considered radioactive and was released from any further controls. There were also controls on movement of property between locations on site, but these are not relevant to this report and are documented elsewhere.

\subsection{Potential Dose to the Public}

The maximum possible dose to members of the public due to SLAC are very small compared with doses from natural background radiation and are well below all regulatory limits. 
Table 5-6 summarizes the dose results for the two modes that were the potential contributors to public radiation dose in 2005: direct radiation and airborne radioactivity. Releases of radioactivity in water and property were too small to result in a radiation dose to a member of the public under any imaginable scenario. The reported maximum dose for the MEI, dominated by direct radiation, is based on a person being present 24 hours per day in 2005 at the location near Sand Hill Road, approximately 650 m (2,133 feet) northeast of the intersection of Sand Hill and Whiskey Hill Road.

Table 5-6 compares the 2005 dose results with regulatory limits and natural background. Like previous calculations, the 2005 calculation of the MEI dose does not include any dose reduction for hills that may lie between the locations of dose measurements and the MEI. However, since 2003, the effects of air attenuation for direct photon radiation calculations (a factor of 40) are taken into account.

Table 5-6 Summary of Potential Annual Doses due to SLAC Operations in 2005

\begin{tabular}{|c|c|c|c|c|}
\hline & $\begin{array}{l}\text { Maximum Dose to } \\
\text { General Public - } \\
\text { Direct Radiation }\end{array}$ & $\begin{array}{l}\text { Maximum Dose to } \\
\text { General Public - } \\
\text { Airborne } \\
\text { Radioactivity }\end{array}$ & $\begin{array}{l}\text { Maximum Dose to } \\
\text { General Public - } \\
\text { Airborne + Direct }\end{array}$ & $\begin{array}{l}\text { Collective Dose } \\
\text { to Population within } \\
80 \mathrm{~km} \text { of SLAC }\end{array}$ \\
\hline Dose from SLAC in 2005 & $0.2 \mathrm{mrem}$ & 0.04 mrem & $0.25 \mathrm{mrem}$ & $\begin{array}{l}0.7 \text { (direct) }+ \\
0.2 \text { (air) }=0.9 \\
\text { person-rem }\end{array}$ \\
\hline $\begin{array}{l}\text { DOE Radiation Protection } \\
\text { Standard }\end{array}$ & 100 mrem & 10 mrem & 100 mrem & n/a \\
\hline $\begin{array}{l}\text { SLAC } 2005 \text { Max. Dose as } \\
\text { Percentage of DOE Standard }\end{array}$ & $0.2 \%$ & $0.4 \%$ & $0.25 \%$ & $\mathrm{n} / \mathrm{a}$ \\
\hline $\begin{array}{l}\text { Dose from Natural } \\
\text { Background }\end{array}$ & 100 mrem & 200 mrem & 300 mrem & $\begin{array}{l}1,667,000 \text { person- } \\
\text { rem }\end{array}$ \\
\hline $\begin{array}{l}\text { SLAC } 2005 \text { Max. Dose as } \\
\text { Percentage of Natural } \\
\text { Background }\end{array}$ & $0.2 \%$ & $0.03 \%$ & $0.1 \%$ & $0.0001 \%$ \\
\hline
\end{tabular}

Table 5-7 presents the maximum dose potentially received by a member of the public from direct radiation and airborne radioactivity due to SLAC operations in 1995 through 2005 and compares it with the average dose due to natural background radiation and radioactivity.

\subsection{Biota Dose}

The DOE technical standard, "A Graded Approach for Evaluating Radiation Doses to Aquatic and Terrestrial Biota” (DOE-STD-1153-2002), suggests that DOE facilities protect plants and animals by assuring the following doses' rates due to "exposure to radiation or radioactive material releases" into the applicable environment are not exceeded:

- Aquatic animals: should not exceed $1 \mathrm{rad} /$ day

- Terrestrial plants: should not exceed $1 \mathrm{rad} /$ day

- Terrestrial animals: should not exceed $0.1 \mathrm{rad} /$ day

The term rad is a unit used to quantify radiation dose 
Table 5-7 Potential Dose (mrem) to Maximally Exposed Individual, 1996-2005

\begin{tabular}{cccc} 
Year & $\begin{array}{c}\text { SLAC Direct } \\
\text { and Airborne } \\
\text { Radiation }\end{array}$ & $\begin{array}{c}\text { Average, Total Natural } \\
\text { Background Radiation }\end{array}$ & $\begin{array}{c}\text { Percentage of } \\
\text { Background }\end{array}$ \\
\hline 1996 & 4.6 & 300 & 1.53 \\
1997 & 4.2 & 300 & 1.40 \\
1998 & 4.6 & 300 & 1.53 \\
1999 & 4.5 & 300 & 1.50 \\
2000 & 5.7 & 300 & 1.90 \\
2001 & 5.3 & 300 & 1.77 \\
2002 & 2.1 & 300 & 0.70 \\
$2003^{*}$ & 0.2 & 300 & 0.07 \\
2004 & 0.2 & 300 & 0.07 \\
2005 & 0.3 & 300 & 0.1 \\
* & Starting with the 2003 calculations, the effects of air attenuation (a factor of 40) were taken into account.
\end{tabular}

\subsubsection{Dose to Biota from Direct Radiation}

In 2005, SLAC monitored dose and dose rate at approximately 250 on-site locations (indoors and out) using passive radiation dosimeters posted for three to six month periods. For each period, the average dose rate among these 250 dosimeters was found to be less than $0.002 \mathrm{rad} /$ day. Given this monitoring program and the fact that we know animal populations could not have been present except in locations with average dose rates of less than $0.002 \mathrm{rad} /$ day, doses to plant and animal populations at SLAC were well within the limits of the DOE standard throughout 2005.

\subsubsection{Dose to Biota from Activation Products}

In 2005, SLAC tested soil and water samples for the presence of radioactivity in excess of natural background, as described in sections 5.5 and 5.6. Tritium was occasionally found in industrial wastewater in 2005, but plant and animal populations have no opportunity for access to industrial wastewater at SLAC. Since the radioactive activation concentrations in these monitoring wells are much lower than from direct radiation, there is no possibility that plants or animals will receive dose rates that exceed the limits of the standard due to radioactive activation products at SLAC.

In 2005, no groundwater was found with tritium concentrations in excess of the drinking water standards set by state and federal regulations. Section 5.5.3 summarizes the 2005 results of monitoring for radioactivity in groundwater. There is no possibility that plants or animals will receive dose rates that exceed the limits of the standard due to radioactive activation products at SLAC.

\subsection{Low-level Radioactive Waste Management}

Low-level radioactive waste (LLRW) is produced at SLAC sporadically. Prior to 2002, wastes resulting from routine operations have not been tracked as a category separate from other operations such as one- 
time upgrade, equipment failure replacement, and special projects. A system is now in place to allow tracking of routine operation wastes.

LLRW minimization is accomplished through education and training for the waste generator, careful planning of work operations, thorough survey and characterization of materials, segregation, reuse, and volume reduction when applicable.

SLAC continues to manage its LLRW in compliance with all applicable laws and regulations. During calendar year 2005, SLAC shipped 1285 cubic feet of LLRW to appropriate treatment and disposal facilities. 



\section{Groundwater Protection and Environmental Restoration}

\subsection{Introduction}

This chapter describes the groundwater protection and environmental restoration programs at SLAC, in particular the processes for soil and groundwater evaluation used to achieve the Stanford University goal of unrestricted future use of the site.

\subsection{Background Conditions}

The groundwater regime at SLAC and nearby off-site areas has been comprehensively documented in the SLAC Hydrogeologic Review completed in $1994 .{ }^{30}$ This report compiles data and summarizes results of the numerous geologic, hydrogeologic, and hydrogeochemical investigations that had taken place at or near SLAC for the following reasons:

- Water resources studies

- Research

- Geotechnical studies (used to site structures being built at SLAC)

- Environmental monitoring

The report developed a conceptual model of the groundwater regime at SLAC. Based on many tests in exploratory borings and wells, the hydraulic conductivity of this bedrock is much less than the range of that generally accepted as representing natural aquifer material. In other words, the groundwater at SLAC is not suitable as a drinking water source because of low flow (as well as high total dissolved solids). In 2001, a report was submitted to the RWQCB requesting exemption for groundwater at SLAC as a potential municipal or domestic supply source, based on criteria specified in state and RWQCB resolutions 88-63 and 89-39, respectively. ${ }^{31}$ The request was denied, stating that a basin plan amendment would be required to exempt groundwater from some potential uses.

30 Stanford Linear Accelerator Center, Hydrogeologic Review (SLAC-I-750-2A15H-002, 1994)

31 Stanford Linear Accelerator Center, Demonstration that Natural Groundwater Conditions at SLAC Meet Exemption Criteria for Potential Sources of Drinking Water (SLAC-I-750-A32H-004, October 2001) 


\subsection{Areas with Potential Impact from Chemicals}

A SLAC 1994 report entitled Summary and Identification of Potentially Contaminated Sites ${ }^{32}$ provides a summary of areas that may have been impacted by chemicals of interest. Information for the report was collected from a variety of sources including incident reports, aerial photographs, operations records, reports on previous investigations, and interviews with personnel throughout the facility. As other potentially impacted areas were identified, they were incorporated into a master list. These sites were evaluated and ranked based on the need for further investigation.

Based on further investigation, six groundwater sites, sediment in two drainage channels, and a storage area known as the bone yard are being monitored and remediated as necessary. Each of these sites is discussed below.

\subsection{Strategies for Controlling Potential Sources of Chemicals}

Strategies for chemical source control involve measures to control known soil or groundwater impacts as discussed in the rest of this chapter, and procedures and requirements to avoid practices that could adversely affect soil and groundwater as discussed in chapters 4 and 5 . These procedures include the site's SWPP $^{33}$ and SPCC, ${ }^{34}$ which discuss BMPs for preventing adverse impacts from spills and operations at SLAC.

\subsection{Restoration Activities}

SLAC first began to develop a comprehensive environmental restoration program in 1991. Program activities range from discovery and characterization to remediation and long-term monitoring or maintenance where required. The restoration approach at SLAC is to accomplish the following steps:

- Identify sites with actual or potential impacts (involving soil, groundwater, surface water, and/or air)

- Prioritize impacted sites based on site complexity, nature of chemical impact, associated risks, remaining data needs, and projected remedy

- Investigate sites and identify remedies that protect human health and the environment, beginning with the highest-priority sites

- Implement remedies and monitor for effectiveness

As of 2005, SLAC had generally reached the third and fourth steps. Investigative and remediation work proceeded for the impacted sites discussed in this chapter. EP personnel continued investigations for site characterization and evaluation of remedial alternatives during 2005.

32 ESA Consultants, Stanford Linear Accelerator Center, Summary and Identification of Potentially Contaminated Sites (February 1994)

33 Stanford Linear Accelerator Center, Environment, Safety, and Health Division, Environmental Protection and Restoration Department, SLAC Stormwater Pollution Prevention Plan (SLAC-I-7500A16M-002)

34 - Spill Prevention, Control, and Countermeasures Plan (SLAC-I-750-0A16M-001), https://www-internal.slac.stanford.edu/esh/documents_internal/SPCC.pdf 
SLAC follows the general CERCLA technical guidance in investigating and remediating soil and groundwater. SLAC was not listed in the National Priorities List as a Superfund site because USEPA determined that the conditions at the site did not warrant inclusion.

The RWQCB provides oversight and approval of restoration activities that impact surface or groundwater at SLAC. The SMCHSA oversees final confirmation sampling of environmental restoration activities involving remediation of chemically impacted soil.

In May 2005, the RWQCB issued a new board order (No. R2-2005-0022) to SLAC for the investigation and remediation of impacted soil and groundwater resulting from historical spills and leaks that occurred during the course of operations at SLAC. The board order addresses numerous release sites at SLAC and consolidates the investigation and cleanup activities at the facility. It also rescinds an earlier board order that addressed contamination at only one of the sites, the FSUST site, which is now incorporated into the new board order.

\subsection{Groundwater Characterization Monitoring Network}

Under the new board order, SLAC has developed a self-monitoring program (SMP) that contains a monitoring schedule for sediment from two drainage channels, surface water, and groundwater. As part of the new SMP, SLAC transitioned from a quarter to a semester monitoring schedule during 2005. The SMP outlines the frequency at which monitoring samples are to be collected and the chemicals of interest they are analyzed for. Work continued in 2005 on installing additional monitoring and extraction wells. Figure 6-1 shows the monitoring network.

SLAC has 126 wells across the site used for groundwater monitoring and extraction. Figure 6-2 and Figure 6-3 identify the specific well locations. The groundwater monitoring wells are used to monitor general groundwater quality in the major areas of the facility that historically or currently store, handle, or use chemicals. Of the 126 wells, 85 wells are used to monitor chemicals of potential concern in six plumes and 28 wells are used as extraction wells for two of the six plumes. The other 13 groundwater monitoring wells are monitored for general site-wide surveillance. The six locations where plume monitoring occurs include the following:

1. Former Hazardous Waste Storage Area (FHWSA)

2. Former Solvent Underground Storage Tank (FSUST) site

3. Test Lab and Central Lab areas

4. Plating Shop area

5. Lower Salvage Yard

6. Beam Dump East

Table 6-1 summarizes the wells at SLAC by location, number, and purpose of the wells. 


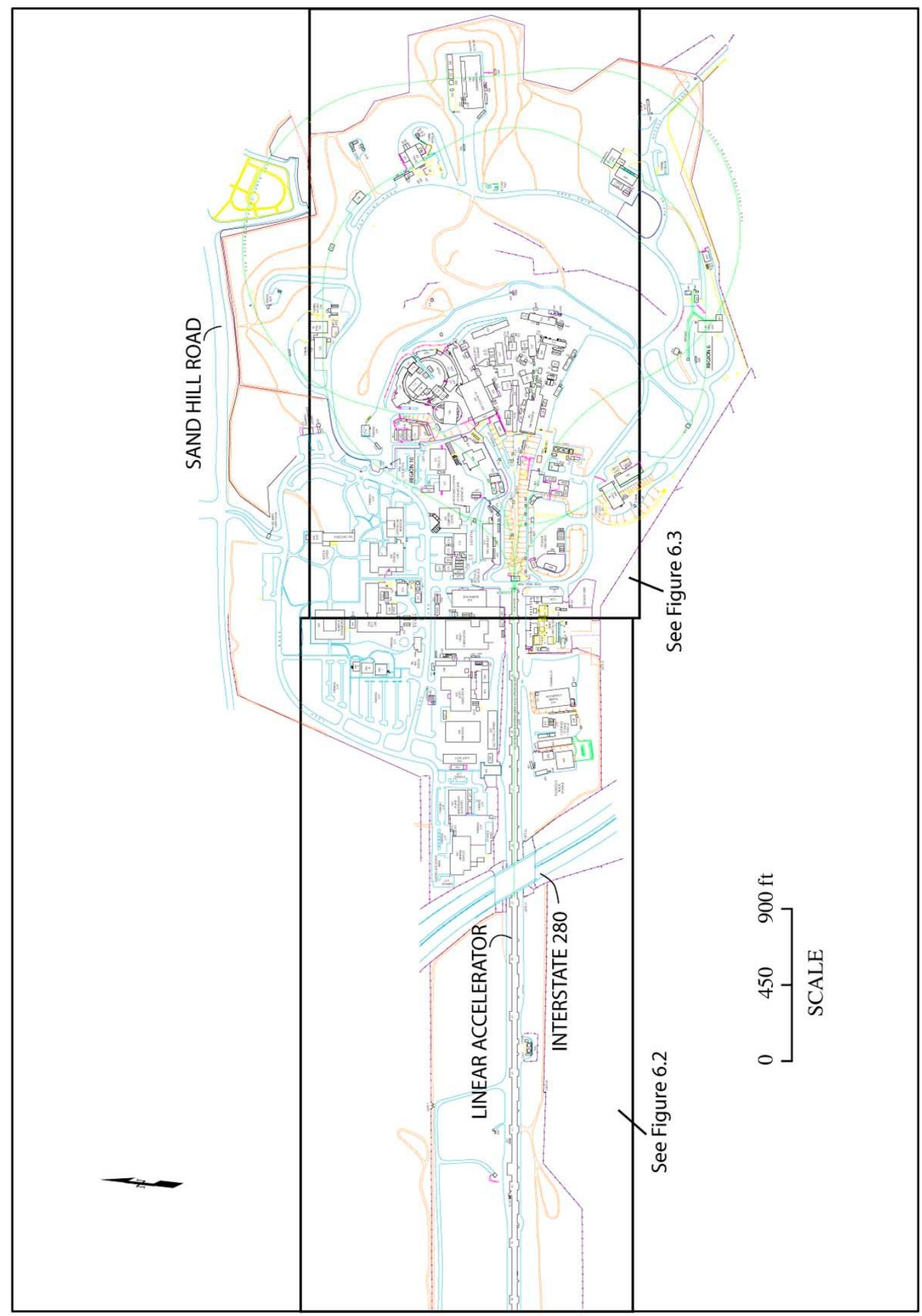

Figure 6-1 Groundwater Characterization Monitoring Network 


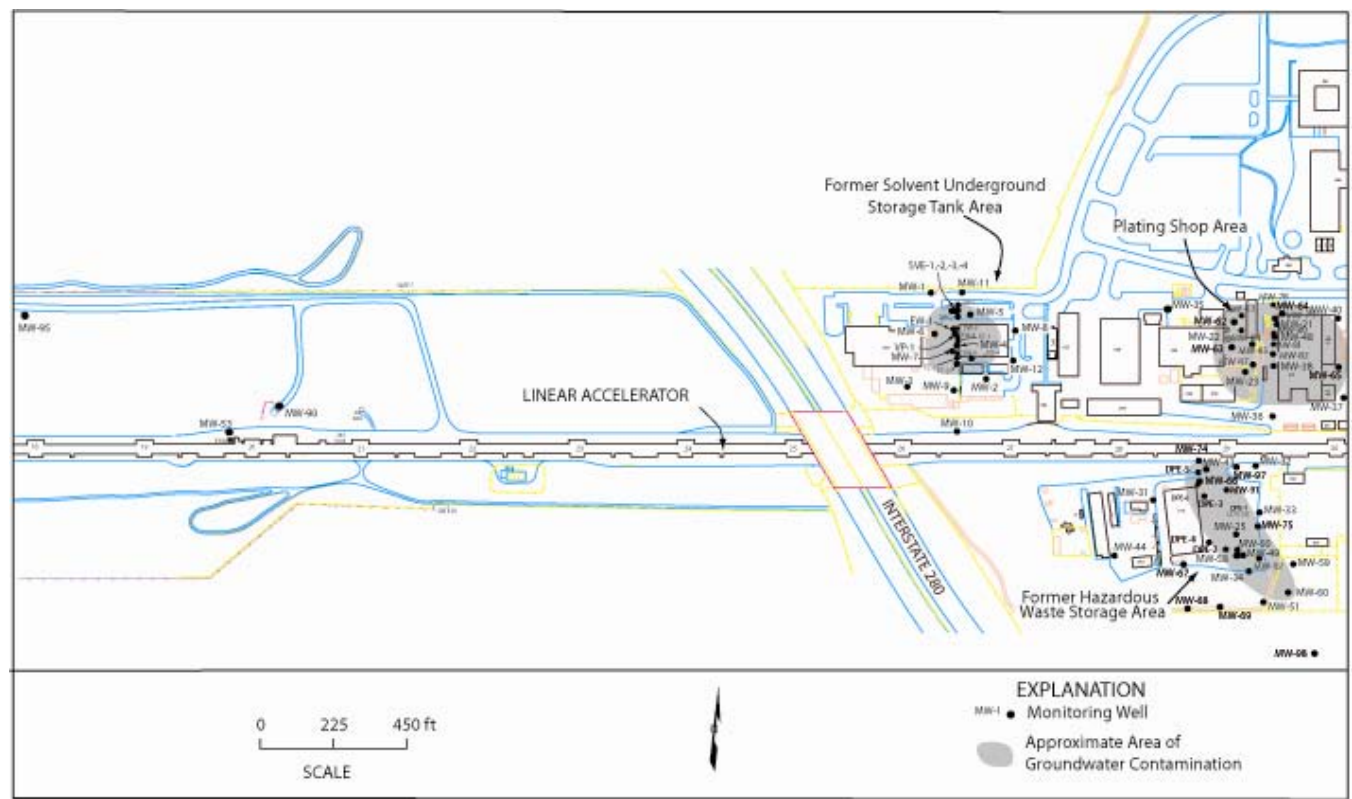

Figure 6-2 Westside Groundwater Network and Impacted Areas

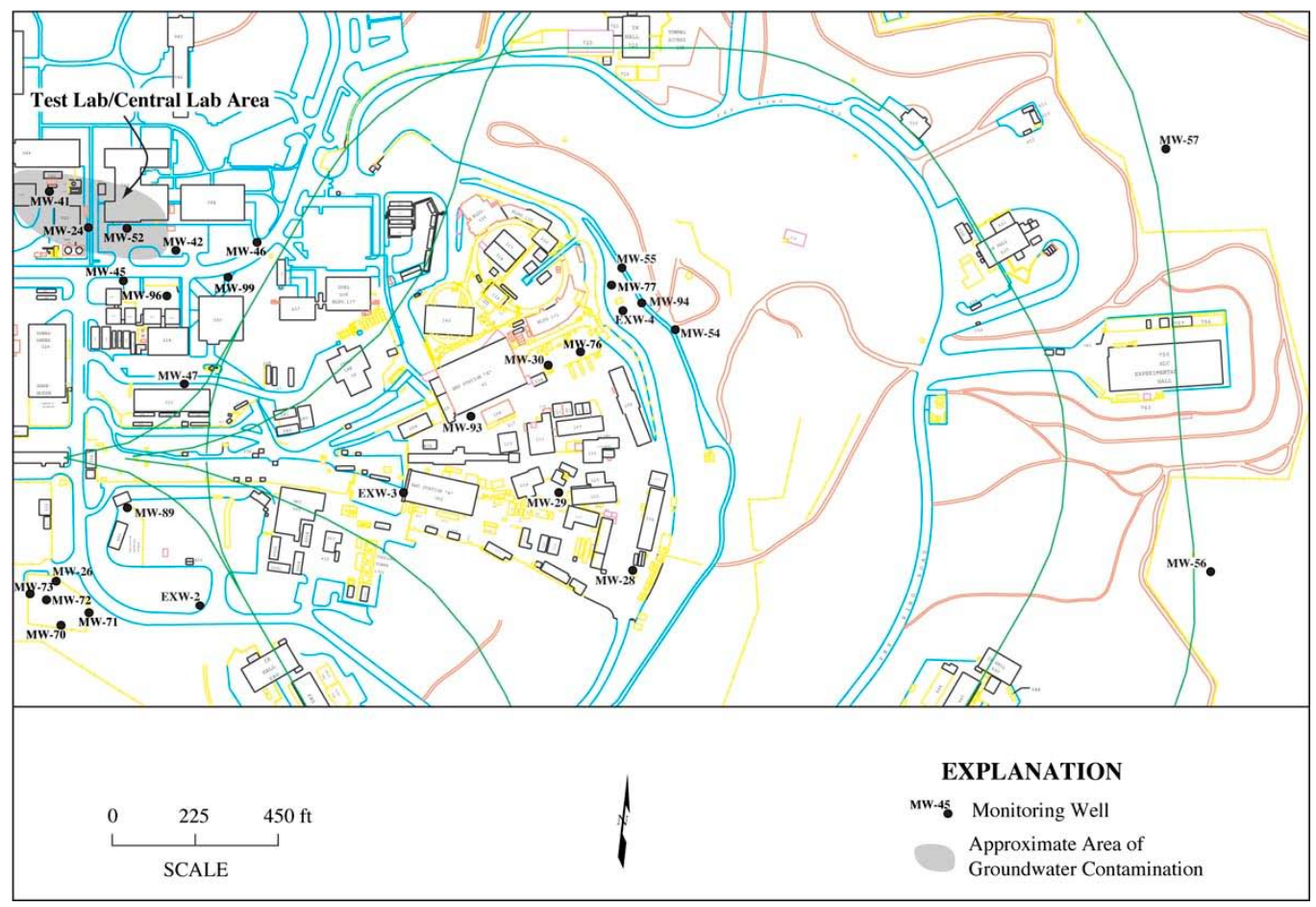

Figure 6-3 Eastside Groundwater Network and Impacted Areas 
Table 6-1 Monitoring Locations and Number of Wells

\begin{tabular}{lr} 
Location & Number \\
\hline Plume Monitoring & 6 \\
Beam Dump East & $22^{*}$ \\
Former Hazardous Waste Storage Area & 22 \\
Former Solvent Underground Storage Tank & 5 \\
Lower Salvage Yard & 21 \\
Plating Shop & 9 \\
Test Lab and Central Lab & 85 \\
Subtotal & \\
Extraction & 5 \\
Former Solvent Underground Storage Tank & $23^{*}$ \\
Former Hazardous Waste Storage Area & 28 \\
Subtotal & \\
Environmental Surveillance & 1 \\
Centralized Waste Management Area & 1 \\
End Station B & 2 \\
Magnet Yard & 5 \\
Other (remote) & 13 \\
Research Yard & 3 \\
Vacuum Assembly & 1 \\
Subtotal &
\end{tabular}

* Four monitoring wells are now listed as extraction wells because they were converted in 2005

Groundwater samples were collected at least once from 113 wells in 2005 and analyzed for a variety of constituents. The results of groundwater monitoring of wells were reported to the RWQCB in the semiannual self-monitoring report for the winter of $2005^{35}$ and the summer of $2005{ }^{36}$ The groundwater analytical results were generally within each well's historic range of concentrations. Samples were analyzed for one or more of the following:

- Total petroleum hydrocarbons (TPH)

- Metals

- Polychlorinated biphenyls

35 Stanford Linear Accelerator Center, Semi-annual Self-Monitoring Report, Winter 2005 (EP 0503-01, March 2005)

36 — , Semi-annual Self-Monitoring Report, Summer 2005 (SLAC-I-750-2A15H-015, December 2005) 
- Total dissolved solids (TDS)

- General minerals

- Tritium

- VOCs and semi-volatile organic compounds (SVOCs)

\subsection{Groundwater Site Descriptions and Results}

The six groundwater sites are described below. The sites pose no current risk to human health or the environment. Through the work described below, remediation strategies that protect current and future potential uses of the property are being defined. All samples are submitted to an analytical laboratory certified by the California Department of Health Services.

\subsubsection{Former Solvent Underground Storage Tank}

A groundwater monitoring network is located in proximity to the SLAC Plant Maintenance building in the northwestern portion of the main SLAC campus (see Figure 6-2). This network consists of 22 wells used to monitor the migration of chemical constituents associated with the FSUST site. The FSUST was used to store organic solvents from 1967 to 1978. A pressure test performed on the FSUST in 1983 indicated a leak. The FSUST and accessible chemically impacted soil were removed in December 1983. A network of 22 monitoring wells and five extraction wells were subsequently installed, and groundwater has been monitored for VOCs and SVOCs.

The evaluation of remedial alternatives report for the FSUST established remedial action objectives and then evaluated 42 alternatives to determine which would meet best the objectives. ${ }^{37}$ The selected remedial alternative for the FSUST, a groundwater extraction and treatment system, was constructed at the FSUST area during the summer of 2001 as a pilot system and has been in operation since August 27, 2001. The system was constructed for testing the effectiveness of a five-well extraction system for achieving hydraulic control of the small area of chemically-impacted groundwater. Chemicals of interest in groundwater in the FSUST area include VOCs and SVOCs. SLAC has submitted to the RWQCB the Interim Groundwater Extraction and Treatment Implementation Report and Monitoring Plan for the FSUST Area. $^{38}$

Since the start up of the groundwater extraction system in August 2001, 367,000 gallons of water have been extracted and treated, resulting in the removal of $263 \mathrm{lbs}$ of VOCs and SVOCs. Monitoring well data collected thus far indicate a capture zone encompassing the entire plume has been established and chemical data indicate that the plume appears to be shrinking in size.

\subsubsection{Former Hazardous Waste Storage Area}

The FHWSA was in use from approximately 1973 to 1982. During closure of the FHWSA, PCBs were found in shallow soils. As a result, several inches of topsoil were removed. A monitoring well was installed

37 Stanford Linear Accelerator Center, Evaluation of Interim Remedial Alternatives for the Former Solvent Underground Storage Tank Area (SLAC-I-750-3A-33H-006, 2003)

38 Stanford Linear Accelerator Center, Interim Groundwater Extraction and Treatment Implementation Report and Monitoring Plan for the Former Solvent Underground Storage Tank Area (SLAC-I-7503A33H-016, October 2004) 
in this area in 1990, and VOCs were detected in the groundwater. Since then, two soil gas surveys have been performed; and, 22 monitoring wells, 23 extraction wells, and more than 50 soil borings have been installed at this site. Figure 6-2 shows the limited extent of VOCs in the groundwater.

In 2002, a dual-phase groundwater/soil vapor extraction (DPE) pilot test proved promising to treat impacted soil, soil vapor, and groundwater, and was recommended as a suitable remediation technology. Two DPE wells were installed at the FHWSA in 2003 as part of an interim dual-phase extraction (IDPE) system. The IDPE system has been in continuous operation since January 20, 2004. Since that date, a total of 50,100 gallons of water have been extracted and treatment of soil vapor has resulted in the removal of approximately $20 \mathrm{lbs}$ of VOCs. The design of a full scale DPE system for the FHWSA was finalized in $2004 .{ }^{39}$ Construction of the full scale system, which will utilize 23 extraction wells, began in June 2005 and is anticipated to be completed in early 2006.

\subsubsection{Plating Shop}

In 1990, three monitoring wells were installed down-gradient of the Plating Shop. Constituents of interest were detected in all three wells; and an investigation began and included installation of additional monitoring wells, a soil gas survey, and remediation beneath a steam cleaning pad.

A total of 21 groundwater monitoring wells are currently located at the Plating Shop Area. Groundwater sampling results indicate that chemicals are present in groundwater within three co-mingled plumes. In support of further investigation efforts, a total of 13 soil vapor probes were installed at the Plating Shop Area in December 2004, and the probes were sampled in January and February 2005. The draft site characterization report for the Plating Shop Area was submitted to the RWQCB in December 2003. No comments have been received from the RWQCB regarding the draft site characterization report. ${ }^{40} \mathrm{~A}$ draft remedial alternatives evaluation report ${ }^{41}$ has been prepared which recommended soil vapor and groundwater extraction followed by treatment.

\subsubsection{Test Lab and Central Lab}

A monitoring well was installed between the Test Lab and Central Lab in 1990 at the site of a former, leaking, diesel pump spigot. Chemically impacted soil was removed and the well was installed to monitor for the possible presence of diesel fuel. Diesel has never been detected in this well, but chlorinated solvents have been.

Data from a soil gas survey, soil borings and additional monitoring wells installed in the Test Lab and Central Lab area helped delineate the sources of contamination. Results of the investigation indicated three possible source areas for VOCs, including one adjacent to the Test Laboratory, and two adjacent to the Central Laboratory. A new perimeter well was installed in August 2005 to monitor the groundwater quality down-gradient of a well which reported the presence of VOCs for the first time in 2001.

39 Erler \& Kalinowski, Technical Specifications and Drawings for the Dual Phase Extraction and Treatment System at the Former Hazardous Waste Storage Area (2004)

40 Stanford Linear Accelerator Center, Environment, Safety, and Health Division, Draft Site Characterization Report for the Plating Shop Area (SLAC-I-750-3A33H-12, December 2003)

41 Erler \& Kalinowski, Inc., Remedial Alternatives Report for the Plating Shop Area, Stanford Linear Accelerator Center, Menlo Park, California (December 2003) 
Results of the investigative work at the Test Lab and Central Lab area were detailed in the site characterization report for the Test Lab and Central Lab area, which the RWQCB approved in $2002 .{ }^{42}$ An evaluation of remedial alternatives report was also prepared for the Test Lab and Central Lab Area and submitted to the RWQCB in 2002. ${ }^{43}$ In April 2003, the RWQCB provided comments to the remedial alternatives evaluation report. SLAC responded to the comments in July 2003. The RWQCB approved proceeding with the finalization of the report in September 2004.

\subsubsection{Beam Dump East}

Beam Dump East is an area in which the high-power electron beam is terminated during experiments in End Station A. Groundwater in the immediate vicinity of Beam Dump East contains tritium at levels within those acceptable for drinking water. The groundwater is monitored in six wells at least two times per year. In 2005, as in previous years, the monitoring indicates that the tritium is localized to two wells in the area of the beam dump.

\subsubsection{Lower Salvage Yard}

As discussed below in Section 6.8.1 historically, there have been minor detected petroleum hydrocarbons and VOCs have been detected in wells at the Lower Salvage Yard. This site is discussed further below.

\subsection{Soil Site Description and Results}

In addition to the groundwater sites discussed above, SLAC is also investigating soil sites which have been impacted by chemicals of interest, primarily PCBs, lead and TPH. These sites are discussed below. In one area, the Interaction Region (IR)-6 and IR-8 drainage channels, sediment in drainage channels have been impacted with chemicals of interest and work continues to investigate these areas. At the LSY, the groundwater continues to be monitored and additional soil removal is planned.

\subsubsection{Lower Salvage Yard}

The LSY has been used for storage of salvaged equipment, including those that are oil-filled, as well as materials such as scrap metal. Prior to its use as a salvage yard, the first SLAC substation occupied part of the area.

Site characterization data indicated several chemicals of interest including PCBs and petroleum hydrocarbons were present above cleanup levels. Thus a removal action was initiated in 1999. A total of 3,114 tons of material were excavated from the yard to achieve the clean-up goal of $1 \mathrm{ppm}$ PCBs, but PCBs above the clean-up goal remained in the side walls of the excavation. Accordingly, additional excavation is planned for the future.

The five monitoring wells at the LSY were sampled in 2005. No chemicals were reported in any of the samples collected.

42 Stanford Linear Accelerator Center, Environment, Safety, and Health Division, Test Laboratory and Central Laboratory Site Characterization Report (SLAC-I-750-3A-33H-009, July 2002)

43 Erler \& Kalinowski, Inc, Draft Evaluation of Remedial Alternatives for the Test Laboratory and Central Laboratory Area (July 2002) 


\subsubsection{IR-6 and IR-8 Drainage Channels}

Much of SLAC's stormwater runoff is conveyed by the IR-6 and IR-8 drainage channels, which ultimately discharge into San Francisquito Creek. Surface water runoff from the Research Yard drains into the manmade IR-6 drainage channel partially located off site. IR-8, also primarily located off site, is a natural ephemeral drainage that was engineered during SLAC construction to accept groundwater from the accelerator and PEP sub-drainage systems and surface water runoff from the campus area at SLAC.

PCBs and lead were first found in the off-site portions of the IR-6 and IR-8 drainages in 1990. An investigation to further characterize the extent of PCBs and lead was performed and included a 2.5-mile segment of San Francisquito Creek. No PCBs were detected in the creek samples. In 1995, the removal and off-site disposal of PCB and lead impacted sediments from the IR-6 drainage channel and its upstream stormwater catch basins were performed.

In 1996, it was found that sediments with PCBs were still entering the IR-6 drainage channel. Since 1996, additional investigations and remedial work have been completed to identify and remove additional potential upstream sources of PCBs and lead.

Sediments in the IR-6 and IR-8 drainage channels and off-site downstream reaches have been monitored annually since 1998. The annual collection of sediment samples shows that despite remediation efforts, PCBs persist in sediments entering the IR-6 and IR-8 channels' drainages, although at levels significantly lower than historic concentrations.

A number of projects have been completed since 2004 as a follow up to detections of low levels of PCBs and lead found in a drainage channel located downstream of the IR-6 and IR-8 drainage channels, off of the SLAC leasehold boundary. As a result, SLAC completed an extensive field investigation study. The results of the field investigation showed that PCBs and metals associated with a plastic, recycled wire groundcover used by the adjacent leasehold, contributed to the detections found in the drainage. SLAC's contribution to the PCB detections in the channel, if any, could not be established.

\subsubsection{Bone Yard and Related Projects}

The Bone Yard is an undeveloped outdoor storage area located between the linac and the north access perimeter road, at Sectors 12 and 13 of the linac. It has been in use since 1964, and used for the storage of concrete blocks of all sizes, large iron ingots, steel sheeting and other pieces of iron/steel scrap metal originally used in radiation shielding applications as part of high-energy experiments at SLAC since 1966. Lead, in the form of lead wool, wire and shot, was historically placed between the concrete blocks to provide additional radiation shielding. Bundles of steel rods known as bullet stock was another type of shielding historically used to reduce beam energy during experiments and had also been stored for many years at the Bone Yard. The steel rods are approximately 0.35 inches in diameter and 12 feet long, and typically held together by wire in bundles of 15 or more. Interspersed within these bundled steel rods were lead wire and lead shot.

Approximately 3,100 bundles of these steel rods had been placed in the Bone Yard in the early 1970's, stored in about 50 steel racks covering an area of about 4,800 square feet. In September 2005, each bundle of the lead-impacted steel rods was opened, and individually cleaned to remove the lead, then shipped offsite to be recycled as scrap metal. A small number of the steel rods (about 1,000) were found to be slightly radioactive. The radioactive rods were disposed of as radioactive waste. To remove lead fragments that had fallen from the bundles of rods, the underlying soil and asphalt were vacuumed and the top 1 to 2 inches of soil was excavated following removal of the lead-impacted rods. Approximately 20 cubic yards of surface 
soil was removed and shipped off-site as Non-RCRA Hazardous Waste. The lead fragments and other debris associated with the work were disposed of as hazardous waste.

In October 2005, a small number of bullet stock bundles located at two other locations at SLAC were handled in the same manner. Six racks and two wooden crates containing bundles of bullet stock were cleaned at SLAC's Radioactive Material Storage Yard, and two racks plus a wooden pallet of bullet stock were cleaned at IR-4. In addition, the pavement at two locations in the Research Yard where bullet stock was known to have previously been located was also cleaned with a HEPA vacuum to remove pencil lead and lead shot.

\subsubsection{Excavation Clearance Program}

During 2005, the excavation clearance program continued to support SLAC-wide projects to ensure proper disposal of excavated soil. An excavation clearance permit must be completed for activities that involve excavation or relocation of soil at SLAC. The form is intended to reduce worker exposure to hazards associated with excavation work at SLAC, including underground utility lines, chemical contamination, and radiological hazards and ensure proper management and disposal of excavated materials. More than 44 projects were supported by this program during 2005. 



\section{A Distribution List}

\begin{tabular}{|c|c|c|c|}
\hline Name & Title & Organization & E-mail \\
\hline Arnold Edelman & Physical Scientist & $\begin{array}{l}\text { DOE, Environment, Safety and } \\
\text { Health Division }\end{array}$ & arnold.edelman@science.doe.gov \\
\hline Raymond Hardwick Jr & $\begin{array}{l}\text { Deputy Assistant } \\
\text { Secretary for } \\
\text { Facility Safety }\end{array}$ & $\begin{array}{l}\text { DOE, Environment, Safety and } \\
\text { Health Division }\end{array}$ & raymond.hardwick@eh.doe.gov \\
\hline Van Nguyen & $\begin{array}{l}\text { Supervisory Safety } \\
\text { and Occupational } \\
\text { Health Specialist }\end{array}$ & $\begin{array}{l}\text { DOE, Environment, Safety and } \\
\text { Health Division }\end{array}$ & van.nguyen@science.doe.gov \\
\hline Rosario Natoli & $\begin{array}{l}\text { Environmental } \\
\text { Protection } \\
\text { Specialist }\end{array}$ & $\begin{array}{l}\text { DOE, Office of Air, Water and } \\
\text { Radiation }\end{array}$ & Ross.Natoli@hq.doe.gov \\
\hline Patricia Dehmer & Associate Director & $\begin{array}{l}\text { DOE, Office of Basic Energy } \\
\text { Sciences }\end{array}$ & patricia.dehmer@science.doe.gov \\
\hline Robin Staffin & Associate Director & DOE, Office of High Energy Physics & robin.staffin@science.doe.gov \\
\hline Gertrude Dever & $\begin{array}{l}\text { Associate Director, } \\
\text { Laboratory } \\
\text { Operations and } \\
\text { ES\&H }\end{array}$ & $\begin{array}{l}\text { DOE, Office of Laboratory Policy } \\
\text { and Infrastructure }\end{array}$ & leah.dever@science.doe.gov \\
\hline Walter Warnick & Director & $\begin{array}{l}\text { DOE, Office of Scientific and } \\
\text { Technical Information }\end{array}$ & walter.warnick@science.doe.gov \\
\hline Glenn Podonsky & Director & $\begin{array}{l}\text { DOE, Office of Security and Safety } \\
\text { Performance Assurance }\end{array}$ & Glenn.Podonsky@oa.doe.gov \\
\hline Allan Chiu & Permit Engineer & $\begin{array}{l}\text { Bay Area Air Quality Management } \\
\text { District }\end{array}$ & achiu@baaqmd.gov \\
\hline Gary Butner & Acting Director & $\begin{array}{l}\text { California Department of Health } \\
\text { Services, Radiologic Health Branch }\end{array}$ & gbutner@dhs.ca.gov \\
\hline George Leyva & & $\begin{array}{l}\text { Regional Water Quality Control } \\
\text { Board, San Francisco Bay Region }\end{array}$ & gleyva@waterboards.ca.gov \\
\hline Dean Peterson & & $\begin{array}{l}\text { San Mateo County Department of } \\
\text { Health Services, Office of } \\
\text { Environmental Health }\end{array}$ & dpeterson@co.sanmateo.ca.us \\
\hline David Boesch & City Manager & City of Menlo Park & dsboesch@menlopark.org \\
\hline $\begin{array}{l}\text { Magaly Bascones } \\
\text { Dominguez }\end{array}$ & & CERN, Library, Periodicals Unit & $\begin{array}{l}\text { magaly.bascones.dominguez } \\
\text { @cern.ch }\end{array}$ \\
\hline
\end{tabular}

